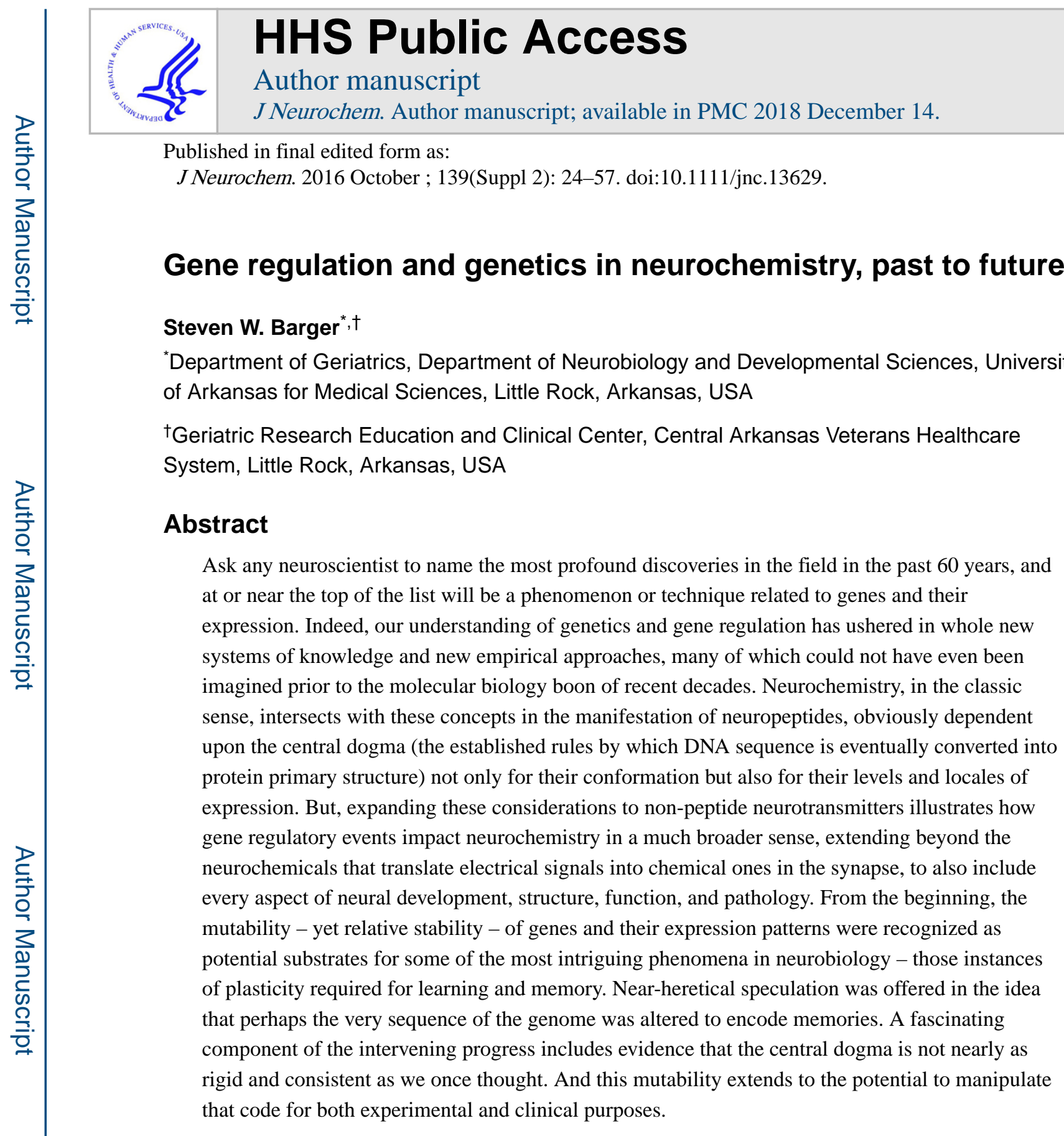

\title{
Keywords
}

Central Dogma; chromosomal instability; epigenetics; history of medicine; next-gen sequencing; transcription

Address correspondence and reprint requests to Steven W. Barger, Donald W. Reynolds Institute on Aging, 629 Jack Stephens Drive, \#807, Little Rock, AR 72205, USA. bargerstevenw@uams.edu. 


\section{Gene transcription}

\section{Transcription factors}

Soon after the structure of DNA had been determined, in both generalized terms of the helix and specific terms of individual gene sequences, it became clear that an understanding of how genes are regulated would be at least as exciting and important. Because of their relative simplicity and potential for rapid amplification to biochemical quantities, prokaryotic genomes provided many of the early discoveries, such as the fact that certain primary genes could influence the activity of other secondary genes physically distant in the genome. Systematic quests for the agents of this 'trans-acting' phenomenon soon determined that proteins, expressed by the primary genes, conducted some of the most important trans effects, often by binding specific and predictable sequences within the secondary genes. These DNA-binding sites of transcription factors are responsible for a great many of the identified 'cis-acting' elements, sequences within a given gene that control its own expression. Once bound to a cis element, a transcription factor typically acts to recruit the RNA polymerases necessary for transcription. These and related phenomena were soon demonstrated in eukaryotes, as well, where the complexity of chromatin structure (more below) afforded interactions of transcription factors not only with RNA polymerase II, for instance, but also with histone acetyl transferases and other proteins of the 'transcriptosome' complex. Early studies on the role of gene regulation in ontological events meant that a great many hormones, growth factors, and similar agents were found to activate transcription factors critical for development, including that of the nervous system. But, some of the most intriguing roles for transcriptional regulation in the CNS related to neurotransmission and synaptic plasticity, and it was not long before gene regulatory events were invoked to explain these and other aspects of neurochemistry.

AP-1-Curran and colleagues (Morgan et al. 1987; Shin et al. 1990) created quite a stir when they presented evidence that neuronal activity was associated with induction of the cFos protooncogene under disease models of epileptiform states. Perhaps, more consequential was the demonstration of c-Fos induction as a consequence of physiological changes in neuronal activity, including trans-synaptic induction in second-, third-, and perhaps fourthorder neurons in a circuit (Hunt et al. 1987; Sagar et al. 1988). This opened up the potential to use c-Fos elevation as an index of connectivity. Similar forms of regulation were eventually discovered for other members of the c-Fos family, such as FosB (Chen et al. 1995). Protooncogenes, the normal versions of genes that can foster neoplasia when mutated, had been the subject of intense scrutiny in the early 1980s as essential players in mitosis and tissue pattern development. But, just as the neurotrophin nerve growth factor was found to share tyrosine phosphorylation and other signal transduction elements with mitogens such as epidermal growth factor, parallels in those transduction pathways were found to extend to transcription factors and gene regulation. Still, it was somewhat novel at the time to consider that ion channels and other mediators of rapid neurotransmission could intersect with the same pathways.

The transcription factor formed by c-Fos is AP-1, a heterodimer of a Fos with a member of the c-Jun family. Although the regulation of c-Fos and its contribution to AP-1 is nearly 
always dependent upon changes in quantity, the Jun proteins were found to be regulated by growth factors and cytokines primarily via rapid phosphorylation, namely by Jun N-terminal kinase (JNK) (Derijard et al. 1994). However, many neural phenomena in which Jun-family proteins participate appear to require induced expression, similar to that for c-Fos (Morgan and Curran 1988; Sonnenberg et al. 1989; Oo et al. 1999). Jun has been connected to a host of biological phenomena in neurons, with particular emphasis on roles in neuroplasticity and death from trophic factor withdrawal (Raivich 2008).

Of particular relevance to AP-1 and its modulation by JNK are the many aspects of neuroinflammation in which that kinase participates. Cytokines, chemokines, and pathogen- $/$ danger-associated molecular pattern ligands often activate JNK. Indeed, an impact of such immune-related stimuli on neurochemistry is manifest in the induction of the serine racemase gene (Srr) by JNK activation of JunB (Wu and Barger 2004). This induction of Srr by a JunB-containing AP-1 may even involve activation of an alternative transcriptioninitiation site (Figs 1 and 2). The resulting elevation of serine racemase in activated microglia is responsible for their production of D-serine, the most abundant and relevant agonist of the 'glycineB' site of the NMDA receptor in the forebrain (Van Horn et al. 2013). In addition to potentially contributing to excitotoxicity, the elevated tone for NMDAreceptor activity could create transient, less drastic perturbation of neurotransmission. The role of JNK in neuroinflammation is covered more thoroughly in other contributions to this special issue (Feinstein 2016).

CREB-The correlation of Fos and Jun factors with neurophysiology and neurochemical stimulation found rational explanations in the connections that were being established at the time between such protooncogenes, mitogens, and calcium. Many growth factor receptors are coupled to activation of phospholipase $\mathrm{C}$, resulting in production of inositol trisphosphate, which activates release of calcium from stores in the endoplasmic reticulum. Considerable evidence indicated that cell-surface calcium channels are often activated too, in part to provide calcium for refilling the ER stores. It was soon determined that a major component of the activity-dependent induction of Fos was secondary to the activation of cyclic AMP-responsive element-binding (CREB) protein. CREB is activated by phosphorylation, and the first relevant kinase identified was cAMP-activated kinase (PKA). But, it was eventually determined that calcium/calmodulin-activated kinase II (CaMKII) could perform this role as well. And given the critical contribution that calcium makes to neurotransmission, it is not surprising that neurochemists led the charge in exploration of this aspect of CREB regulation. First came colocalization of phospho-CREB and CaMKII, which was reported in a retinal system in which elevation of calcium was shown to mimic photostimulation in the elevation of both CREB phosphorylation and c-Fos expression (Yoshida et al. 1995). Soon, calcium-dependent activation of CREB came to be recognized as an important connection between neurochemical signals that elevate intracellular calcium, such as glutamate receptors, and gene regulatory events (Dash et al. 1991; Sheng et al. 1991; Fukuchi et al. 2014).

Of course, discoveries of CREB activation by CaMKII does not mean that PKA is irrelevant to CREB in the nervous system. As would be predicted by the array of neurotransmitters and other neuroactive agents coupled to cAMP production, the PKA-CREB axis is involved in a 
host of neural events, such as induction of the tyrosine hydroxylase gene (Piech-Dumas et al. 2001). Indeed, the respective reliance on calcium or cAMP may be specific to brain region and/or cell type (Moore et al. 1996). In some cases, cAMP- and calcium-mediated pathways may cooperate to effect a super-induction of CREB-dependent transcription (Hansen et al. 2004). There is even evidence that the capacity for calcium-dependent activation of CREB reflects a permissive state that is established through the integration of neuronal activity patterns by PKA activation over time (Pokorska et al. 2003). (This concept is discussed at greater length below.)

CREB is involved in important non-neuronal events in the nervous system too, such as glial differentiation and reactivity. Inflammation-related stimuli activate the CREB-Fos axis in primary glial cultures (Simi et al. 2005). Several agents impacting oligodendrocyte differentiation rely on CREB (Sato-Bigbee et al. 1999). Astrocytic expression of proenkephalin appears to involve a phosphorylation of CREB by a Src-related kinase (Kobierski et al. 1999).

NF B family-Once the floodgates of neurochemical-transcriptional interactions had been opened, investigators began to test many different transcription factors for roles in the nervous system. One family that appeared intriguing was that contained under the rubric 'nuclear factor $\kappa$ light chain enhancer of activated B cells' NFkB. Canonical NFkB, most commonly comprising a heterodimer of NFKB1/p50 with RelA/p65, was known to dwell in the cytoplasm until rapid activation is effected via liberation from a tonic inhibitor I $\kappa B$ when the latter is targeted for degradation by the ubiquitin/proteasome system. This seemed an ideal system for conveying signals from post-synaptic compartments to the neuronal nucleus to effect the gene regulatory aspects of neuroplasticity. In a classic example of confirmation bias, a spate of publications reported activation of $\mathrm{NF \kappa B}$ in cultured neurons by glutamate receptor agonists and other neurochemical stimuli. Most of these paradigms appear to have been confounded by artifacts of glial contamination of the cultures or supraphysiological over-expression of active NFKB subunits via transfection or viral transduction (reviewed in Mao et al. 2009). Studies performed in intact animals or acute tissue slices have often correlated neuronal activity or neuropathology with active NFKB in homogenized tissue extracts (Cardenas et al. 2000; Nakai et al. 2000; Madrigal et al. 2001; Hu et al. 2005). But these paradigms, of course, include the potential for contributions from glia, endothelial cells, etc.

For the purposes of understanding transcriptional regulation in post-mitotic neurons, one can almost dismiss out-of-hand NFkB studies that were performed in 'neuronal' cell lines derived from neuroblastomas or other tumor cells, since shown to be poor representatives of this and other aspects of differentiated neurons. Nevertheless, NFкB has important roles in proliferative activity and survival properties in tumors; so, its activity may persist and even contribute to neuroblastoma. This is implied by preclinical studies being conducted with the NFKB inhibitor bortezomib, which appears to hold some promise in the treatment of neuroblastoma (Sholler et al. 2013), as it has proved to be useful in treatment of other cancers. 
Regardless of the problems with early studies on glutamatergic regulation of NFKB, evidence exists to suggest that the protein subunits have some natural biological role in neurons. For instance, NFkB ablation or inhibition inhibits neurite outgrowth and synapse formation (Imielski et al. 2012; Saleh et al. 2013; Su et al. 2013). It is possible that these involve some mechanism other than activation of gene transcription. For instance, NFrB can physically interact with glucocorticoid receptors, inhibiting their transcriptional effects (Fig. 1). It is noteworthy that RelA/p65 has been documented to translocate from the cytosol to the nucleus even in neurons where it does not activate RNA transcription (Barger et al. 2005), similar to its behavior in other paradigms (Mukaida et al. 1994; Brostjan et al. 1996; Ray et al. 1997; Harant et al. 1998; Wang and Baldwin 1998). Nevertheless, more sophisticated techniques have provided evidence for some amount of NFKB activity in neurons. In particular, a Cre/Lox system has been employed to deplete RelA/p65 from neurons, and this was documented to reduce the expression of a luciferase reporter gene containing a NFkB-responsive promoter (Boersma et al. 2011). In the end, there is ample evidence that $\mathrm{NFKB}$ proteins - while present in CNS neurons - fail to participate in robust gene transcription in these cells (Jarosinski et al. 2001; Srinivasan et al. 2004; Saha and Pahan 2007; Mao et al. 2009; Lian et al. 2012, 2015; Listwak et al. 2013; Dvoriantchikova and Ivanov 2014). Such might be the expectation for a family of proteins extensively documented to participate in self-sacrificial inflammatory states, such as the surface expression of major histocompatibility complex I proteins (Drew et al. 1993; Rall et al. 1995). Unusual aspects of this system in neurons apparently extend to NFkB-inducing kinase, which participates in non-canonical activation of the transcription factor in other cell types, yet appears to inhibit NFrB in post-mitotic neurons (Mao et al. 2016).

Roles for NFkB are very well established in glia. In astrocytes, it is activated by amyloid $\beta$ peptide (A $\beta$ ) and lipopolysaccharide (LPS) (Dodel et al. 1999), mediating the latter's induction of glucose 6-phosphate dehydrogenase (Garcia-Nogales et al. 1999) and glucose transporter 3 (Cidad et al. 2001), and it mediates the induction of interleukin 6 by bradykinin (Schwaninger et al. 1999) and of glial fibrillary acidic protein by interleukin 1 (Krohn et al. 1999). Indeed, the contributions of NFkB to these and other aspects of the innate immune system, particularly in microglia (Laflamme and Rivest 1999; Bruce-Keller et al. 2001; Nicolini et al. 2001; Liu et al. 2005), make this transcription factor family extremely important to every aspect of neuroinflammation. Anti-inflammatory drugs such as aspirin and ibuprofen even owe a portion of their effectiveness to 'off-target', yet serendipitous inhibition of NFkB (Kopp and Ghosh 1994; Scheuren et al. 1998).

Sp1 family-One of the first eukaryotic transcription factors ever identified was Specific protein 1 or, as it is known universally now, Sp1. Indeed, this appears to have been the first eukaryotic transcription factor for which the gene was cloned. Eventually, other family members were isolated and cloned, including $\mathrm{Sp} 2,-3$, and 4; but, $\mathrm{Sp} 1$ was considered to be the ubiquitous family member among mammalian tissue and cell types. Indeed, there appeared to be a considerable amount of Sp1 in neurons, as it was identified as the factor occupying a substantial subset of $\mathrm{NF \kappa B}$ target sequences under the neuronal conditions of paucity for the latter. Sp1 has a somewhat broad specificity for sites that can be said to generally possess high GC content, and most NFkB target sequences are GC-rich. DNA 
sequences containing optimal Sp1-binding sites were found to efficiently compete for binding to the proteins that were found constitutively interacting with these NFKB sequences in nuclear extracts from CNS neurons. However, antibodies to Sp1 did not appear to interact with these proteins, and they were eventually determined to be a mixture of $\mathrm{Sp} 3$ and $\mathrm{Sp} 4$ (Mao et al. 2002). Indeed, this is one of the few settings in which Sp4 is present. Indeed, Sp1 was found to be essentially replaced by Sp4 during neuronal differentiation (Mao et al. 2009; Milagre et al. 2012). The significance is not entirely clear; but, Sp4 is generally less active as a transcriptional activator, and many Sp1-induced genes are active in cell proliferation. This suggests that Sp4 replaces Sp1 to suppress mitotic genes in neurons, which will no longer need them and, in fact, may suffer from their expression (Wang et al. 2009).

The Sp3 and -4 DNA-binding activity in neurons is vulnerable to cytosolic calcium overloads. In neurons treated with abusive levels of glutamate-receptor agonists, Sp3 and -4 DNA binding is diminished, and the remaining activity has a faster migration consistent with proteolysis (Mao et al. 2002). This effect can be blocked with calcium chelator or inhibitors of the calpain proteases. Thus, some portion of the calcium-dependent phenomenon of excitotoxicity may involve degradation of $\mathrm{Sp} 3$ and -4 . This appears to lead to liberation of at least one Sp1-induced mitotic gene (Mao et al. 2009). It remains to be determined whether or not this contributes to excitotoxicity via the documented ability of mitotic signals to foster apoptosis in neurons (Liu and Greene 2001).

Nuclear receptors-Many steroid hormones and other small, lipophilic molecules bind and modulate proteins that physically interact with DNA and components of the transcriptosome essentially as transcription factors. Estrogen receptors provide a classic example of such ligand-dependent transcription factor (Gruber et al. 2002). Other, similar factors are the glucocorticoid/mineralocorticoid receptors, thyroid hormone receptor $\left(T_{3} R\right)$, retinoid-activated receptor, 9-cis retinoic acid receptor (RXR), liver X receptors (LXR), and peroxisome proliferator-activated receptors (PPAR). A considerable amount of the progress made in the past 60 years on the actions of these ligand-receptor pairs relates to their interactions with other components of the nuclear transcriptional control mechanisms. In particular, several members of the LXR and RXR families act via corepressors for other transcription factors such as nuclear receptor corepressor $(\mathrm{N}-\mathrm{CoR})$ and silent mediator of retinoic acid receptor and thyroid receptor (Perissi et al. 1999; Hu et al. 2003). RXR and GC modulate the actions of the nuclear orphan receptor Nurr1 in neurons (Wallen-Mackenzie et al. 2003; Carpentier et al. 2008).

Roles for nuclear receptors in cellular differentiation and other aspects of development were predicted by groundbreaking studies on the ontological effects of retinoic acid, intensified to a focus on individual genes regulated by retinoids (Suzuki et al. 1995; Cheung et al. 1997). It was only a matter of time before the nuclear receptors for these retinoids were invoked to explain their effects on such genes (Nikcevic et al. 2008; Murakami et al. 2010), as well as on broader phenomena such as hippocampal neuron morphology (Liu et al. 2008), astrogliogenesis (Faigle et al. 2008), and control of inflammatory states (van Neerven et al. 2010). 
The nuclear receptors are particularly important to neuroinflammation. There is an extensive literature on the antiinflammatory effects of estrogens (Giatti et al. 2012; Petrone et al. 2014). The PPAR family generally contributes to antiinflammatory effects when activated by ligands such as prostaglandin J2 (Xu et al. 2008). An LXR agonist also attenuates inflammation in an experimental model of spinal cord injury (Paterniti et al. 2010).

The LXR and retinoid-activated receptor/RXR factors and their interactions have gained substantial interest in the field of Alzheimer's disease, due in part to the role for lipid homeostasis in that disease implied by apolipoprotein E genetics. When activated by ligand, LXRa and - $\beta$ induce the expression of ATP-binding cassette transporters (especially, A1 and G1) and other gene products involved in the transport of cholesterol and other lipids. A natural agonist of LXRs, 24S-hydroxycholesterol, creates conditions that facilitate transport of cholesterol - in the context of lipoprotein particles - from individual cells in culture (Burns et al. 2006) and into the CSF in vivo (Fujiyoshi et al. 2007), presumably shifting the gradient from the brain parenchyma. This may explain, in part, why LXR-knockout mice exhibit degenerative accumulations of cholesterol in the CNS (Wang et al. 2002). RXRs participate in the homeostasis of lipids and $\mathrm{Ab}$ in the brain as well, as illustrated by the ability of RXR agonist bexarotene to reduce (at least, temporarily) amyloid burden in A $\beta$ overproducing models of Alzheimer's disease (Cramer et al. 2012).

Transcription factors in neuroplasticity-From the earliest applications of molecular biology to neuroscience, investigators hypothesized about the potential for genes and their activity to serve as a physicochemical substrate for long-term changes such as those required for learning and memory. Although an individual protein or small-molecule metabolite may have a half-life of only seconds or hours, the expression patterns of genes obviously represent a form of stability that lasts a lifetime. Mechanistically, the capacity for transcription factors to integrate neurophysiological signals may depend on a difference in the natural rhythms created by the relative kinetics of these two modes of activity. The kinetics of biochemical events regulating transcription factors - protein phosphorylation, acetylation, ubiquitination, degradation, etc. - are generally slower than most electrochemical events that mediate neurotransmission. Therefore, for those transcription factors that are impacted by the ions and signaling cascades set in motion by neurotransmitter receptors, a volley of depolarizations can induce post-translational modifications more rapidly than they can be reversed, generating a summation or 'recording' of the activity, e.g. through nuclear translocation or transcription of second-order transcription factors such as Fos (Fig. 2). The possibility that such modifications can be converted to a somewhat irreversible form by epigenetic mechanisms could reinforce the stabilization of the record.

One undesirable form of neuroplasticity is drug addiction, and AP-1 and the Fras are impacted in these paradigms. Drugs of abuse such as opiates and cocaine induce an acute elevation of c-Fos and other Fras such as FosB, Fra-1, Fra-2, and DFosB. But, chronic addiction models produce attenuation of these responses, mirroring many other aspects of drug dependency; the acute Fras are replaced, however, by the 'chronic Fras' (Laorden et al. 2002; Larson et al. 2010; Nunez et al. 2010), which now appear to be somewhat longer alternative splice variants of the conventional 33-kDa $\Delta \mathrm{FosB}$ (Chen et al. 1997). In a chronic 
methamphetamine-exposure model, the activation of AP-1 attenuated in second and third exposures, and this was attributable to a recalcitrance of c-Jun rather than its Fos partner (Ishihara et al. 1996). In keeping with evidence that some of the engrained activity patterns responsible for addition also underlie chronic pain, $\triangle \mathrm{FosB}$ is induced in a carrageenaninduced model (Luis-Delgado et al. 2006).

\section{Epigenetic gene regulation}

DNA methylation-The chromosomal DNA of all known species of life undergoes chemical modification in the form of post-replicative methylation (Billen 1968; Lark 1968; Kalousek and Morris 1969; Kappler 1970), including such covalent modification of mitochondrial DNA. DNA methylation occurs most often on the cytosine of a C-G pair (usually referred to as ' $\mathrm{CpG}$ ' in this context), but guanosine is occasionally methylated. Unique to mature CNS neurons and certain stem cell populations is the methylation of cytosines outside of CpG pairs (Xie et al. 2012; Lister et al. 2013; Varley et al. 2013).

DNA methylation suppresses transcription, as first evinced by Venner and Reinert (1973). In the simplest interpretation, the conformational changes in DNA brought about by this modification interfere with the binding of proteins such as transcription factors. However, this explanation is likely incomplete, as several heavily methylated genes are transcribed at a high rate, especially if methyl-CpG-binding proteins are absent. The latter information suggests that it is protein-protein competition that squelches the interactions of the transcriptosome with methylated DNA. This relationship may represent a two-way street: evidence suggests that transcriptionally active genes are less readily targeted by methyltransferase enzymes (Brandeis et al. 1994; Mummaneni et al. 1998), possibly through sheer steric competition (see 'molecular momentum', below). This is particularly likely for the Sp1 family of transcription factors, as their consensus binding sites are all GC-rich.

The inactivation of genes by methylation is a primary means of epigenetic stability. Several key methyltransferases make it their business to methylate the opposite strand at sites where DNA is hemimethylated; in this way, methylation patterns are perpetuated after DNA replication creates the pairing of a methylated strand with a nascent, unmethylated strand. DNA methylation was first recognized as mechanism to confer gene imprinting only 28 years ago (Reik et al. 1987; Sapienza et al. 1987), though this inheritance phenomenon expression of a locus restricted to either the maternally or the paternally derived copy - has been recognized since the 1920s (Boycott and Diver 1923; Sturtevant 1923; Boycott et al. 1930).

Although DNA methylation is considered a means of perpetuating gene expression patterns, it is nevertheless pliable. Methyltransferases rely on methyl donors such as $S$ adenosylmethioine that are cyclically renewed from dietary one-carbon sources. The ability to alter epigenetic gene regulation via environmental and behavioral nuances is well supported by the reliance of DNA methylation on dietary levels of folate, an important contributor to the maintenance of $S$-adenosylmethionine. Deficiencies in vitamin B12 can also compromise methytransferases, many of which use B12 as a cofactor. This is one of the risks associated with alcohol abuse, which often gives rise to B12 deficiencies (Kruman and Fowler 2014). Issues of blood-brain barrier permeability create nuances for the brain's 
utilization of this one-carbon cycle (Long et al. 1989). Failure to maintain proper methylation patterns also seems to be a predictable and efficacious consequence of aging (Horvath 2013; Keleshian et al. 2013), whether through stochastic loss of fidelity in replication or through some other impact of the aging process on the relevant enzymes.

Dietary folate and its impact on DNA methylation is illustrated in an interesting phenomenon that unites neurological mechanisms with something as esoteric as hair color. The Agouti gene product is a peptide antagonist of melanocortin receptors and thereby suppresses melanin content in hair. In strains of mice bearing the dominant Agouti allele lethal yellow $\left(A^{\text {y }}\right)$, the long-terminal repeat of a retrotransposon has been inserted in the promoter region of the Agouti gene, causing ectopic expression of the agouti peptide. This results in antagonism of the MC4R receptor in the hypothalamus, leading to hyperphagia, obesity, insulin resistance, and a shortened life span, as well as a yellow coat color (Hidaka et al. 2001). However, hypermethylation of the $A^{y}$ promoter can be forced via a high-folate diet. This suppresses expression of agouti peptide and mitigates the phenotype (Wolff et al. 1998).

The importance of DNA methylation for neural systems is also exemplified by Rett syndrome, which begins postnatally as an autistic-spectrum disorder in girls that progress to profound motor and sensory disability, seizures, cognitive impairment, and a somewhat shortened life span. The disorder is caused by mutations in methyl-CpG-binding protein 2 (MeCP2) (Amir et al. 1999) (though this is something of a misnomer, as the protein binds any methyl-cytosine). The gene for $\mathrm{MeCP} 2$ resides on the $\mathrm{X}$ chromosome, but it is mutated sporadically in most cases, defying an X-linked inheritance pattern; Rett syndrome is observed exclusively in females, as males with a MeCP2 mutation are so severely affected as to die shortly after birth. MeCP2 effects widespread changes in gene expression patterns (Mellen et al. 2012), and loss of function even at adult ages causes disability similar to that of Rett (McGraw et al. 2011), further underscoring the rather unique dependency of the CNS on gene regulation through DNA methylation.

Chromatin structure-A key distinction between prokaryotic and eukaryotic genomes is the presence of higher level structural components such as histones. Histones have been known to biologists since the work of Albrecht Kossel in the late 19th century. But, it was only in the 1980s that Michael Grunstein found that histones were able to suppress gene transcription (Han et al. 1987; Grunstein 1990), and a true understanding of the critical role they play in gene regulation would await demonstrations by Vincent Allfrey in the 1990s that this inhibition was dynamic and modifiable (Vidali et al. 1978; Prior et al. 1983), ushering in a key aspect of the modern theory of epigenetic mechanisms. It is now recognized that the steric, conformational interactions of chromosomal DNA with histones critically influence the accessibility of that DNA to the transcriptosome and that this DNAhistone interaction is tightly regulated through post-translational modification of the proteins. In recognition of its profound role in transcriptional regulation, the regulation of histones and their interactions with DNA have been dubbed the Histone Code (Jenuwein and Allis 2001). 
Histones and their modification-Over half a dozen types of modifications of histone residues have been identified, including acetylation, phosphorylation, methylation, monoubiquitination, ADP-ribosylation, citrullination, and SUMOylation. Acetylation is commonly associated with a reduction in the affinity of the histone for DNA, thereby dissolving this association and making the DNA more accessible for transcription. This acetylation is conducted by histone acetyltransferases, generally considered an important component of the transcriptosome complex. Their action is opposed by the histone deacetylases, critical players in gene silencing (Anekonda and Reddy 2006). The other modifications of histone are not as universal in their outcome as acetylation. Methylation and ubiquitination of specific residues on specific histones can either promote or inhibit transcription (Kouzarides 2007). Indeed, contextual fear learning is associated with two separate histone methylation events, each of which has an opposite effect on transcription (Gupta et al. 2010). Likewise, phosphorylation events can either facilitate or inhibit acetylation, and thus transcription (Rossetto et al. 2012).

Histone modification and cellular differentiation-Early in the investigation of these mechanisms, it was determined that silencing the expression of specific genes via tight association of DNA with histones is a key element of cellular differentiation. Neurons, of course, are often considered among the most highly differentiated cells in the vertebrate body plan. However, CNS neurons are known for their relatively high euchromatin-toheterochromatin ratio, manifest as a large nucleus with rather pallid staining by nucleophiles. Indeed, the Nissl substance in neuronal cytosol often accrues denser staining than does the nucleus. Euchromatin is recognized as being the template of active transcription, thus marking neurons as the most diverse transcript venue. This is consistent with the findings that (i) histone acetylation levels are higher among neurons than glia and (ii) neuronal differentiation of neural progenitor cells is fostered by an HDAC inhibitor (Hsieh et al. 2004; Yellajoshyula et al. 2011). Thus, it would appear that neurons are distinct from most other cell types in their requirement for relatively high levels of histone acetylation during (and after) differentiation.

The neuronal histone code is largely attributable to a master regulatory factor known as RE1-silencing transcription factor (REST; AKA neuron-restrictive silencer factor, NRSF). Originally identified as a protein that silences neuronal genes in mature non-neuronal cell types, REST is now known to play a critical role in the maintenance of a tenuous neuronal potential through the transition of neural stem cell to mature neuron (Ballas et al. 2005). Key to this discussion is the manner in which REST exerts its effects: The protein exerts transcriptional repression via recruitment of histone deacetylases, G9a histone methyltransferase, and heterochromatin protein-1 (HP-1) to specific genes in nonneuronal and undifferentiated cells. This results in cell type-appropriate expression of individual genes critical for the differentiated phenotype of important neuronal classes, such as the NR1 component of the NMDA receptor (Bai et al. 2003).

Translational impacts of the histone code-Diseases from cancer to epilepsy are associated with gene expression changes that appear to arise from aberrations in histone modification. Generally speaking, deacetylation of histones is important for the quiescence 
of proinflammatory genes expected in a state of health. Microglial activation is dramatically influenced by modulators of histone acetylation, for instance (Suuronen et al. 2003).

Accordingly, hyperinflammatory conditions are generally associated with histone acetylation (Suuronen et al. 2005; Ma et al. 2010; Forgione and Tropepe 2012; Machado-Filho et al. 2014), presumably because the genes for cytokines and their receptors are particularly sensitive to histone deacetylation. To the extent that macromolecular synthesis is required for apoptosis and other forms of programmed cell death, histone modification appears critical to these phenomena as well (Boutillier et al. 2003; Ryu et al. 2005; Yang et al. 2011; Koriyama et al. 2014; Feng et al. 2015). In addition, the relevant enzymes, such as HDACs, can interact with non-histone proteins such as Tau in a disease-relevant manner (Ding et al. 2008; Perez et al. 2009).

Histone modification is a pharmacologically tractable modality. Current drugs impact global histone acetylation and thus one might expect that they would be limited to conditions in which the primary defect is one that alters the histone code universally. However, butyrate has been used successfully to treat a seizure condition resulting from inheritance of a glycosylphosphatidylinositol deficiency (Almeida et al. 2007).

If specificity beyond the general histones is required clinically, it may be afforded by targeting less universal proteins. REST is typically restrained in the cytosol of neurons, and this appears to fail in Huntington's disease. A drug-discovery project has identified compounds that have shown preliminary success in a screen aimed at restoring the cytosolic retention of REST in Huntington's (Conforti et al. 2013).

The nuclear envelope-The condensation of DNA around histones is not the only means by which nuclear structure influences transcription. Considerable evidence indicates that interaction of chromatin with the nuclear envelop also makes an impact (Gay and Foiani 2015). The lamins, nuclear envelope proteins that contribute to this structure, appear to be negatively impacted by ethanol and thereby participate in the untoward effects of ethanol on astrocyte gene expression (Marin et al. 2008). An intriguing array of signal transduction enzymes - phospholipases, kinases, GTPases, ubiquitin ligases/proteasomes, and the like have been localized to the cellular nucleus in recent years. The lamins appear to participate in regulating these localizations (Garcia Del Cano et al. 2014; Koliou et al. 2016).

Epigenetics in neuroplasticity-In addition to the medium-/long-term integration of neural activity that transcription factors mediate (above), some aspects of gene regulation also appear to be critical for the integration of experiences and exposures that can be passed transgenerationally from parent to offspring (or even grandoffspring). It has become increasingly clear that epigenetic control over gene expression is malleable, and impacts on the epigenetic status of chromosomes in an individual's gametes can change patterns and propensities for gene expression in his/her progeny. Natural and pharmaceutical agonists of PPAR $\gamma$ can create an acute leptin resistance (Hosoi et al. 2015); this and similar conditions have often been found to convey in a heritably vertical manner from one generation to the next via epigenetic mechanisms (Masuyama and Hiramatsu 2012). As might be expected, given the connections between such metabolic disturbances and inflammation, one finds a high potential for epigenetic transmission of the inflammatory state. Tumor necrosis factor is 
more readily elevated by 6-hydroxydopamine in the substantial nigra of rats that had been exposed to LPS in utero (Ling et al. 2004), and microglia generally express more proinflammatory genes when obtained from animals that had been exposed to LPS in utero (Cao et al. 2015). Such a priming toward inflammation has been associated with a decline in global CpG methylation (O’Brien et al. 2014).

One possible mechanism for the ability of epigenetic phenomenon to integrate experience and have transgenerational conveyance is a sort of 'molecular momentum'. Intuitively, it would seem that a transcriptionally active promoter may be less accessible to DNA methyltransferases, MeCPs, or even histones; the transcriptosome may simply exert steric hindrance on these enzymes locally (Fig. 3). Whether or not this is true, more precise molecular mechanisms have been identified (Jones 2012). Regardless of the mechanism, 'molecular momentum' is consistent with the finding that transcriptional quiescence is achieved prior to DNA methylation (You et al. 2011); and genes that are highly expressed early in the life span - e.g. in utero - tend to continue in high expression in later life stages. It is easy to envision a pregnant dam's environment or behavior making an impact on the conditions that prevail in utero. The vertical transmission of 'molecular momentum' from parent to progeny outside of pregnancy, however, is more demanding; it would require that the transcriptionally active state be extended to the gamete.

\section{Post-transcriptional regulation}

As the beginning of new macromolecular synthesis, gene transcription is a logical control point. But, the decades since the discovery of mRNA have seen the elucidation of a host of subsequent events that control the rate at which genes become proteins. In fact, several elements of these post-transcriptional mechanisms involve genes that exert an impact on phenotype without ever being converted into proteins. Only about 20 percent of eukaryotic transcription is devoted to mRNA (Kapranov et al. 2007). The other genomic sequences that participate in expression encode the 'non-coding' RNAs, and beyond the well-known requisite players rRNA and tRNA are several categories that have complex and intriguing modulatory functions, such as microRNA (miRNA), piwi-interacting RNA, small nuclear RNA, and long non-coding RNA. Many non-coding RNAs are still poorly understood and will likely provide fascinating work for molecular biologists - including some neurochemists - throughout the next 60 years. In addition to those processes that depend on non-coding RNA, there are several post-transcriptional controls that are manifest through conventional enzymology and signal transduction. These are no-less important and are increasingly invoked to explain translational aspects of neurochemistry from disease etiology to the aging process.

\section{Control of translation}

RNA-binding proteins-A practical understanding of post-transcriptional processing, even in its most pedestrian forms, was only possible after the discovery of RNA-binding proteins that are involved in steps such as exon splicing, polyadenylation, and nuclear export. RNA-binding proteins, however, also participate in modulating mRNA translation rates, stability, and subcellular localization. Some of these processes are generalized to 
common elements, e.g. the poly(A)-binding protein which regulates translation rates and stability via interactions with the poly(A) tail of most messages (Bernstein and Ross 1989). Somewhat more interesting are those that interact with discrete sequences in specific mRNAs. Many of these interactions depend upon the formation of RNA secondary structure, such as a stem-loop motif. One of the most instructive classes of structures exemplifying these phenomena are the iron-responsive elements that participate in regulation of proteins involved in iron handling. Ferritin and the transferrin receptor are markedly regulated at the translational level by iron levels, and this occurs via iron-binding proteins that specifically interact with a stem-loop structure in the $5^{\prime}$ untranslated region (UTR) of the ferritin and transferrin receptor mRNAs (Hu and Connor 1996). A similar structure and its interaction with iron-regulatory RNA-binding proteins have also been connected to translational regulation of the amyloid precursor protein by transition metals and, interestingly, by the proinflammatory cytokine interleukin-1 (Rogers et al. 1999). Though a specific binding protein has not been identified, a stem-loop structure in the $3^{\prime}$ UTR of brain-derived neurotrophic factor (BDNF) mRNA is critically involved in a phenomenon by which the message, particularly specific splice variants, is stabilized by neurophysiological activity (Fukuchi and Tsuda 2010).

Musashi is an RNA-binding protein of particular interest to neurobiologists (MacNicol et al. 2008). Maintenance of neural stem cell populations appears to depend upon musashi, and its expression continues into mature astrocytes (Sakakibara and Okano 1997). However, musashi expression levels in the subgranular zone of the dentate gyrus - one of the few areas of adult neurogenesis in the CNS - are correlated with continued expression of neuronal markers in mature dentate granule neurons, illustrating the importance of this RNA-binding protein for maintaining neuropotency. Choline acetyltransferase levels, in particular, wane along with musashi in Alzheimer's disease progression (Perry et al. 2012).

Phosphorylation of ribosomal proteins-Much of what has been learned in recent decades about the translational regulation RNA-binding proteins exert involves their interaction with proteins that play critical roles in the initiation and progression of translation at the ribosome, such as eukaryotic initiation factors (eIF) $2 a, 4 \mathrm{~A}$, and 4G. Modulation of such proteins and their function can also be mediated by post-translational modifications such as phosphorylation. Several of the initiation factors interact with the $5^{\prime}$ 7-methyl-guanosine cap of mRNA, so modification of these proteins and their function alters protein translation globally. Because some mRNAs can be translated independently of the $5^{\prime}$ cap, phosphorylation of these eIFs can change the mix of proteins being synthesized rather than shutting down translation universally (Thakor and Holcik 2012). Nevertheless, phosphorylation of eIF $2 a$ is effected by several stress-related kinases, and the general inhibition of protein synthesis that results can culminate in either energy conservation or - if it is too extensive and lasts too long - cell death. Thus, eIF2a phosphorylation has been connected to the neurodegenerative effects of ischemia, $\mathrm{A} \beta$, and calcium overload (DeGracia et al. 1996; Althausen et al. 2001; Kumar et al. 2001; Chang et al. 2002).

Moderate and reversible changes in protein translation are an appropriate response to limitations in the supply of energy or amino acids. Thus, glucose deprivation typically activates phosphorylation of eIF $2 a$, interfering with the critical action of eIF2 $a$ in 
facilitating the ternary complex of an mRNA's 'Start' ATG with the ribosome and MettRNA. In addition, phospho-eIF2a appears to inhibit (Rajesh et al. 2015) a master regulator that serves to coordinate energy availability with an array of cellular functions from macromolecular synthesis to mitosis to apoptosis: 'mammalian target of rapamycin' (mTOR), so named for its relationship with the first TORs, which were isolated from yeast in the early 1990s. This lynchpin of cell energetics, mTOR, was isolated from mammalian cells a couple of years later. Now recognized to function within a unit comprising important cofactors, more useful characterizations parse mTOR into complexes 1 and 2 (mTORC1 and $-2)$. These moieties have become the focus of intense scrutiny. The lifespan extension properties of caloric restriction appear to involve mTORs, particularly their inhibition; this scheme is consistent with the activation of mTORC1 by insulin/insulin-like growth factor signaling, which is itself generally inhibited under caloric restriction and genetic alterations that extend lifespan (Johnson et al. 2013). In addition, recent research suggests that mTOR inhibition may mimic starvation in a way that activates autophagy (Roscic et al. 2011); to the extent that neurodegeneration involves protein aggregates, stimulation of autophagy is considered a promising therapeutic approach for preventing their accumulation.

A major target of the mTORC1 axis is ribosomal protein S6. Its immediate upstream regulators are members of the S6 kinase family, which includes two major branches: p90rsk, a.k.a. MAPK-activated protein kinase-1, and p70rsk, a.k.a. S6-H1 kinase. The latter also phosphorylates and thereby inactivates eEF2-kinase, leading to a reduction in the levels of phospho-eEF2 and a resultant increase in general translation rate (Wang et al. 2001). But, the more direct actions of S6 kinases and their target S6 itself appear to be somewhat more restricted to the ' 5 ' terminal oligopyrimidine (TOP)' RNAs, those that have a polypyrimidine stretch near the $5^{\prime}$ end and encode proteins that orchestrate responses to nutrients (e.g. glucose/insulin) and (hyper-)trophic signals such as insulin-like growth factor, nerve growth factor (NGF), and BDNF (Matsuda et al. 1986; Cahill and Perlman 1991; Ishizuka et al. 2013). And the examination of the consequences of S6 phosphorylation for those hypothalamic circuits regulating appetite, activity, and glucose disposal accounts for a great deal of the attention devoted to S6 and its kinases in recent years (Ono 2009; Xia et al. 2012).

One can be forgiven for becoming confused about the value and role(s) of mTOR in health and disease. Activation of mTOR has been associated with post-conditioning neuroprotection in models of brain ischemia (Xie et al. 2013), but the remarkable resistance of hibernating squirrels to ischemia has been attributed to their pre-emptive inhibition of mTOR (Miyake et al. 2015). Forsoklin-induced long-term potentiation (LTP) in the hippocampal CA1 depends upon mTOR (Gobert et al. 2008), but mTORC1 appears critically involved in the circuitry reinforcement that facilitates drug dependency (Neasta $e t$ al. 2014). As with other instances of 'antagonistic pleiotropy', there are benefits and disadvantages to mTOR activation; the ultimate conclusion is dependent upon both context (Is there adequate nutrition available to embark on a hypertrophic or neuroplastic cellular endeavor?) and perspective (Is the robust function of an individual cell moot in comparison to the health of the entire organism?) (Fig. 4). 
ER stress-Many of the players active in modulating protein translation as a response to energy depletion and toxins also participate in conveying the translation machinery stresses in the endoplasmic reticulum. The unfolded protein response (UPR) is a stereotypical series of events set in motion by denaturation of nascent proteins in the ER as a consequence of heat, over-expression, or failures in glycosylation (Paschen and Frandsen 2001). Though it includes nuclear events aimed at transcriptional regulation, the UPR exerts a rapid and marked inhibition of protein translation, a reprieve that gives chaperones and other protective mechanisms a chance to clear the backlog and potential aggregation that may arise in the ER. Chief among the mechanisms executing this inhibition of translation is protein kinase RNA-like ER kinase, which acts as a sensor of misfolding in the ER and thereafter inactivates eIF2a (Harding et al. 1999).

Many stressful and toxic circumstances interfere with proper progression of proteins through the ER, and therefore the list of conditions under which UPR is active has continued to grow. Elements of this program have been detected after traumatic brain injury (Nakagawa et al. 2000; Paschen et al. 2004), cerebral ischemia (Kumar et al. 2001; Llorente et al. 2013), 6hydroxydopamine lesions (Holtz et al. 2006), and even sleep deprivation (Naidoo et al. 2005). Indeed, neurodegeneration models that include aggregating proteins - e.g. asynuclein transgenesis (Zagrodnick and Kaufner 1990), parkin knockout (Wang et al. 2008a), parkin-associated endothelin receptor-like receptor overexpression (Kubota et al. 2006), and TDP-43 over-expression (Suzuki and Matsuoka 2012) - have an obvious connection to the UPR. Curiously, however, peroxidative stress has been reported to antagonize the UPR (Paschen et al. 2001). Also reported to be inert or inhibitory for the UPR are Tau-related neurofibrillary pathologies (Spatara and Robinson 2010; Liu et al. 2012b); this might be predicted based on the location of Tau filaments outside the ER secretory pathway. Nevertheless, conflicting evidence exists, suggesting that it may be sufficient for Tau to impinge on the ER externally (Nijholt et al. 2012; Abisambra et al. 2013).

Type-2 diabetes mellitus (T2DM) and the associated insulin resistance seen in prodromal phases have been connected to the UPR of late. This may simply reflect the fact that insulin resistance compromises glucose transporter function, starving the intracellular environment of hexoses; this would likely result in inadequate glycosylation of ER proteins and thereby activate the UPR. However, evidence suggests that a somewhat more complex chain of events involving fatty acid metabolism could be at work. Non-esterified free fatty acids released from adipose appear capable of activating the UPR (Kawasaki et al. 2012). Activation of the UPR by such lipids may be detrimental to any tissue, compromising the health and function of pancreatic $\beta$-cells (Kharroubi et al. 2004; Karaskov et al. 2006), hepatocytes (Pfaffenbach et al. 2010; Achard and Laybutt 2012), or even adipocytes themselves (Miller et al. 2007; Basseri et al. 2009; Han et al. 2013). Some evidence indicates that the UPR exerts its most nefarious effects when activated within the hypothalamic nuclei that control appetite, activity levels, and glucose disposal (Kozuka et al. 2012; Cragle and Baldini 2014). But exercise, which prevents many of the untoward effects of high-fat diets in mice, actually elevates markers of the UPR in the hypothalamus (Kim et al. 2010). In this vein, it is important to recognize that the UPR evolved as an adaptive 
program. Whether it contributes to pathology appears to depend on degree of activation and the weighing of cytotoxicity versus systemic derangement; in this sense, it is somewhat analogous to the Janus-faced characterization of mTOR.

\section{Subcellular localization of mRNA}

Dendritic targeting-Another important development in the maturation of molecular biology - one with a unique relevance to neurobiology - is the discovery that the mRNA products of specific genes are differentially trafficked to subcellular niches for localized translation. Oswald Steward led the way in the early demonstrations of this phenomenon, first documenting the presence of polyribosomes (beads on the 'string' of an mRNA undergoing rapid translation) at the base of dendritic spines (Steward and Levy 1982), illuminating the possibility of protein translation that might contribute to - or be influenced by - synaptic activity. But, the real significance was realized a few years later when Steward and his colleagues demonstrated specific transport of individual mRNAs (Kleiman et al. 1990; Eberwine et al. 2001). Dendrite-specific mRNAs were also found to be enriched in synaptosomes (Rao and Steward 1993), paving the way for utilizing this sort of preparation to explore activity-dependent changes in translation. At the turn of the century, elements of the transport machinery that couple mRNA to microtubule-dependent transport mechanisms were elucidated (Ohashi et al. 2000). The cis elements within the mRNA sequences that underwent specific transport were identified soon after (Miller et al. 2002; Chen et al. 2003).

The implications of targeted delivery of specific mRNAs to specific synapses created immediate excitement in the field. It is true that synaptic plasticity involves, to some extent, localized delivery of the ultimate gene products: proteins themselves. Indeed, the targeting of an mRNA to a specific subcellular locale is mediated by proteins that interact with specific sequence elements in the message (Ohashi et al. 2000; Miller et al. 2002; Chen et al. 2003). However, localized translation provides the capacity for much more rapid changes in the neurotransmitter receptors (Conti et al. 1994; Eberwine et al. 2001), cytoskeletal elements (Kremerskothen et al. 2006; Barker-Haliski et al. 2012), kinases (Wang et al. 2008b), and other critical elements of synaptic plasticity (Huang et al. 2004; Duning et al. 2008). Dendritic transport of proteins that might be needed to establish and/or maintain a potentiated synapse would be expected to take place at $\sim 15 \mu \mathrm{m}$ per hour. By contrast, translation can occur at a rate of 6-10 amino acids per second, stamping out the 905-aa GRIK1, for instance, in just a couple of minutes.

Axonal translation-For several decades dogma held that the axon was a peculiar subcellular domain from which translation was essentially excluded. In fact, Steward's hypothesis about targeted mRNA delivery to dendritic spines was lent considerable support by the inability to detect mRNA delivery to axons (Davis et al. 1987). Like so many rules, however, this one has its exceptions. And the acknowledgment of axonal protein translation need not have awaited the 21 st century. Localized synthesis of acetylcholinesterase and other proteins in mammalian axons was demonstrated only a few years after the christening of the Journal of Neurochemistry (Koenig 1961) and was elaborated upon throughout the 1960s (Koenig 1967a,b). Axonal translation appears to be particularly important during regeneration from injury or axotomy (Koenig and Adams 1982; Perry et al. 1983). 
Eventually, synaptosome preparations, combined with the modern advent of sensitive proteomic approaches, were also used to uncover proteins synthesized within presynaptic boutons (Jimenez et al. 2002). Telomere repeat-binding factor 2 was recently determined to play an important role in facilitating axonal transport of specific mRNAs, a process antagonized by fragile $X$ mental retardation protein (Zhang et al. 2015).

\section{MicroRNA}

For well over half of the 60 years that the Journal of Neurochemistry has been extant investigators have succeeded in manipulating the expression of specific genes by introducing into cells RNA containing the reverse-complement of the targeted genes' mRNA (Stephenson and Zamecnik 1978; Zamecnik and Stephenson 1978; Izant and Weintraub 1984). This 'antisense' approach was one example of several phenomena in which suppression of the levels of an ultimate protein product was effected through naturally occurring or empirically induced RNA hybridization, referred to variously as 'quelling', 'post-transcriptional gene silencing', and 'co-suppression of gene expression'. After many years of attempting to optimize the antisense technique by modifying nucleotides' structure for the sake of stability or more efficiently introducing it into the cell's interior, a key discovery was made by Andrew Fire and Craig Mello when they found that double-stranded RNA worked much more efficiently - substoichiometrically, in fact - compared to singlestranded RNA (Fire et al. 1998).

Fire and Mello shared the 2006 Nobel Prize for showing us (i) that RNAi was mediated most efficiently by dsRNA and (ii) how to harness RNA interference in an empirically practical way. Some viewed their award as an affront to the investigators who discovered some years earlier the natural phenomenon underlying these effects, such as the normal endogenous production of lin-4 in C. elegans (Lee et al. 1993; Wightman et al. 1993) or of antisense RNA for myelin basic protein (Okano et al. 1991). But, whether it was scientific synergism or just good timing, Fire \& Mello (Fire et al. 1998) kicked off a spate of studies that eventually uncovered shared mechanisms uniting empirical manipulation of gene expression and the underlying natural phenomena that the Nobel laureates unwittingly mimicked.

That underlying natural system is now appreciated as a critical form of post-transcriptional regulation of the stability and translatability of mRNA. It is dependent upon noncoding RNA that is initially transcribed from the nuclear genome as a stem-loop structure wherein the stem is highly homologous to one or more mRNA sequences. These non-coding transcripts are referred to as microRNA (miRNA). They are transcribed primarily by RNA polymerase II and often reside within the introns of other, mRNA-encoding genes. In animals, the complementary regions with which they hybridize are typically in the $3^{\prime}$ UTR of mRNAs. Key to understanding the function of miRNA is an appreciation for the multiprotein complex within which it is ultimately processed, resides, and functions. This RNA-induced silencing complex contains one RNase termed 'dicer' that prepares the dsRNA by cleaving it into 2125 basepair fragments. One strand of these oligomers is subsequently combined with the remaining protein subunits of the RNA-induced silencing complex, including a second RNase of the Argonaute family, which is the component that can ultimately cleave the mRNA target. This cleavage of the mRNA actually happens only rarely, however, typically 
requiring a perfect or near-perfect match between the miRNA and the mRNA. More often, the miRNA has several mismatched nucleotides and the resulting hybridization merely inhibits translation. It is perhaps worth noting here that the term 'siRNA' was coined by Elbashir et al. (2001) when they confirmed the work of Hamilton and Baulcombe (1999), Hammond et al. (2000), and of Zamore et al. (2000) showing that larger dsRNA molecules were processed to active, 22-b.p. fragments.

Besides inhibition of translation (with or without mRNA degradation), miRNA can have other effects on gene expression. In some cases, miRNA can suppress transcription via impacts on DNA methylation or histone modification at genomic sites (Bayne and Allshire 2005; Guil and Esteller 2009); in very rare cases, miRNA can even participate in elevation of transcription rates (Li et al. 2006).

\section{Deviations from the central dogma}

If the exception proves the rule, the central dogma is perhaps strengthened by several instances in which the straightforward relationship between gene, mRNA, and protein expression is altered in ways that were initially shocking.

Selenocysteine-From Archaea to mammals, the same set of 20 amino acids is supplied for protein translation by designated tRNA molecules that recognize corresponding mRNA codons. It was something of a surprise when Thressa Stadtman and colleagues reported the presence of a novel amino acid, selenocysteine, in certain proteins (Cone et al. 1976). In these cases, a selenium-containing selenol group takes the place of the sulfur-containing thiol that would otherwise constitute the R-group of cysteine. Often, these selenocysteine proteins are enzymes involved in reduction-oxidation reactions such as glutathione peroxidase, explaining the requirement for selenium as a micronutrient. The biochemical world was in for an even greater surprise when August Böck and coworkers - initially working in bacteria - determined that the thiol of this novel amino acid was not replaced with a selenol moiety through post-translational modification of an intact protein but rather through the cotranslational utilization of a novel tRNA (tRNA ${ }^{\mathrm{Sec}}$ ) that is coupled to extant selenocysteine and acts at the site of a UGA 'stop' codon (Leinfelder et al. 1988). Part of the secret by which this mechanism takes place lies in a specific sequence - a cis element lying just $3^{\prime}$ to the relevant UGA. The tRNA ${ }^{\text {Sec }}$ has an unusually long acceptor arm, the stem-loop structure that interacts with elongation factors. The unique acceptor arm of the tRNASec eschews the typical elongation factor (eEF1A in eukaryotes), favoring instead eEFSec as it interacts with the $3^{\prime}$ cis element (reviewed in Chen and Berry 2003).

RNA editing-Another surprising exception to the central dogma is the modification of mRNA sequences after transcription and routine processing. RNA editing was first reported in the mRNA of mitochondria in the mid-1980s (Benne et al. 1986); eventually, mitochondrial tRNA was found to be edited, as well (Janke and Paabo 1993). But along the way, rather profound consequences were discovered for editing of a nuclear-encoded mRNA that dramatically impacts neurophysiology. From 1991 to 1993, Peter Seeburg and colleagues published a series of articles outlining an editing of the mRNA for three ionic glutamate receptors whereby $1-3$ codons in the mRNA were altered from the genomic DNA 
sequence at incomplete rates, resulting in heterogeneity in the ultimate protein sequences (Sommer et al. 1991; Higuchi et al. 1993; Kohler et al. 1993). Eventually, the laboratories of Tom Maniatis, Richard Axel, and Ron Emeson got into the act, elucidating some of the mechanisms, e.g. adenosine conversion into inosine, through which the codon is recognized by a tRNA anticodon distinct from that which its genomic sequence would dictate. This editing and the resulting amino acid change can result in markedly altered ion permeability of the channel, to calcium, for instance (Kohler et al. 1993).

One of the most consequential changes rendered by editing is in the mRNA for the GluR2 AMPA-receptor subunit (the gene for which is now designated GRIA2). The editing of the so-called $\mathrm{Q} / \mathrm{R}$ site in this protein greatly diminishes calcium permeability of the channels in which it participates (Hollmann et al. 1991); thus, calcium conductance is rare in a-amino-3hydroxy-5-methylisoxazole-4-propionate receptors because of the widespread expressionand editing - of the GluR2 subunit. One exception is the lower motor neurons of the spinal cord, a considerable proportion of which have calcium permeability because of incomplete GRIA2 mRNA editing, a status that may explain some of the selective vulnerability of these cells in motor neuron diseases (Takuma et al. 1999; Greig et al. 2000; Kawahara et al. 2003). Stresses such as ischemia (Peng et al. 2006) or chronic depolarization (Condorelli et al. 1993) can reduce the expression or editing rate of GRIA2, and these conditions have been invoked to explain some instances of excitotoxicity, even in glial cell types (Yoshioka et al. 1995).

Another RNA-editing event is embedded in the unfolded protein response introduced above. One of the first sensors of ER stress is inositol-requiring protein-1 (IRE1), and it participates in the unusual function of executing on-demand, extranuclear mRNA splicing of a single substrate: the mRNA for X-box binding protein-1 (XBP1); IRE1 cleaves the XBP1 mRNA, and the catalytic subunit of the tRNA ligase complex (RTCB) ligates it back together (Ron and Walter 2007; Jurkin et al. 2014). Once updated in this manner, the new XBP1 mRNA is translated into a transcription factor that induces several other components of the UPR.

\section{Genetic instability}

RNA is believed to be older than DNA, which is derived from the former through dehydroxylation of the $2^{\prime}$ ribose carbon; yet, the latter is the substrate for encoding biological blueprints. This seems to be because DNA is more stable, the dehydroxylation having removed the potential for alkaline conditions to instigate a nucleophilic attack by the $2^{\prime}$ hydroxyl on the $3^{\prime}$ bond and thus break the phosphate backbone of an RNA polymer. But the relative stability of DNA is only that: relative. The structure and sequence of our chromosomes is subject to change. Of course, we know this happens through the accidents of mutagenesis; the process of evolution depends on that. What has been surprising is the series of discoveries demonstrating the extent to which the genome is modified, expanded, and abbreviated in a programmatic manner throughout the development of an individual organism. And few tissues exhibit these events, or are affected by them, to the extent seen in the brain. 
Structural variations of the genome include substantial differences (i.e. greater than the single-nucleotide polymorphisms and similarly discrete differences) that exist between individuals but are consistent throughout the body (or, at least, as consistent as any other genomic element). This includes copy number variations (CNVs) that comprise duplication or deletion of sequences that can be several megabases in size (Martin et al. 2015).

In addition to such somatically consistent deviations from the norm, there are somatic mutations and even somatic CNVs in individual tissues or cell types, creating a genomic mosaicism that we are only now beginning to appreciate (Fig. 5). Mosaic variation of chromatin in neurons was documented in invertebrates beginning around 1970 (Coggeshall et al. 1970; Manfredi Romanini et al. 1973). A few investigators reported similar findings in vertebrates, indeed even humans (Brodskij and Kusc 1962; Herman and Lapham 1968; Lapham 1968; Mares et al. 1973). But, these reports went largely unappreciated, in part because of skepticism about the precision of the methods available at that time (Swartz and Bhatnagar 1981). More sophisticated techniques and instrumentation were applied in the 21 st century to confirm 'constitutional' tetraploidy of neurons in the chicken retina (Morillo et al. 2010) and the mouse retina and brain (Lopez-Sanchez and Frade 2013).

In addition to the evidence that whole genomes are duplicated to tetraploidy in a few cells in the brain, there are signs of more piecemeal hyperdiploidy in neurons. Thomas Arendt and others used a sequencing-independent measurement of DNA content per cell (slide-based cytometry) and found that approximately $11 \%$ of neurofilament-positive cells had greater than $2 \mathrm{~N}$ chromatin. Eighteen months later, Fred Gage and colleagues showed that a considerable number of neurons in the human frontal cortex have CNVs at least as large as 1 megabase (McConnell et al. 2013). An additional finding reported by Arendt and coworkers is that the proportion of cells with these CNVs declines with aging. One interpretation is that the CNVs are maladaptive; so, these cells die sooner than the others or cause the individual bearers to develop neurodegenerative diseases (which would have removed these individuals from the pool of neurologically healthy specimens used for the study).

A quarter century ago, Huntington Potter proposed the very novel hypothesis that Alzheimer's disease is a consequence of mosaic Down's syndrome, i.e. aneuploidy for Chromosome 21 in a cell-by-cell basis in the brain (Potter 1991). Over the years, his laboratory and others have produced evidence that supports this idea, including an elevated degree of aneuploidy or hyperdiploidy in Alzheimer brain tissue, i.e. DNA allelic counts that are greater than 2N (Potter 1991; Yang et al. 2001; Rehen et al. 2005; Iourov et al. 2009); the Potter laboratory has also produced evidence that mutated forms of presenilin that give rise to Alzheimer's can interfere with proper mitotic segregation of chromosomes, which might facilitate aneuploidies (Li et al. 1997). Frade and López-Sánchez have more recently proposed that Alzheimer's disease may involve simply an expansion of the frequency with which cortical neurons normally exhibit constitutional tetraploidy (Frade and LopezSanchez 2010). However, other evidence argues against this hypothesis (Westra et al. 2009). Arendt and colleagues posit that a pathological process distinct from what is considered constitutional tetraploidy gives rise to the CNV mosaicism observed in pathological states such as Alzheimer's (Mosch et al. 2007). 
Though there is no evidence that it contributes to the mosaic CNVs discussed above, a startling phenomenon recently observed in CNS neurons further contributes to the impression that these cells are quite different from any other in the body. Lennart Mucke's laboratory reported that double-strand breaks are routinely generated in mouse neurons through normal physiological activity, including that which accompanies exploring a novel environment (Suberbielle et al. 2013). Though spurred by normal learning and memory correlates, the breaks were more extensive and persistent in an amyloid precursor proteintransgenic mouse model. Long-term potentiation is associated with the elevation of reactive oxygen species (Klann et al. 1998), and so were some of the conditions that fostered doublestrand breaks in neurons; this would be consistent with the well-characterized ability of oxidative stress to effect DNA damage. It was somewhat surprising that antioxidants did not impact the generation of double-strand breaks in Mucke's study. Though DNA damage is certainly stressful, only a single observable repair focus was present in about $99 \%$ of the cells showing breaks in this study, and they seemed to recover well over the following 24-h period.

Owing to the error-prone mechanism that predisposes them to disease mechanisms, tri- and hexanucleotide repeats often exhibit somatic mosaicism. Such variety across different tissues and organs is well established in the CAG repeat of huntingtin (Telenius et al. 1994).

Mosaicism has also been reported in the trinucleotide repeats relevant to spinocerebellar ataxias, where it is seen across peripheral tissues, as well as across the brain regions (Tanaka et al. 1996; Hashida et al. 1997; Ito et al. 1998). Mosaicism is also seen in the length of the GAA repeat expansion across various brain regions in Friedreich's ataxia (Montermini et al. 1997). Though the repeat size did not appear to correlate with neuropathological findings in the various regions, mosaicism was invoked to explain dramatic differences in the clinical presentation of two siblings who showed similar repeat counts in the DNA obtained from their leukocytes (Klopstock et al. 1999). Mosaicism also appears to explain a rare occurrence of Rett syndrome (above) in a male; in hair and blood samples, the affected individual had a mixture of wild-type and mutated $M E C P 2$ genes though he had only one $\mathrm{X}$ chromosome (Topcu et al. 2002). Nevertheless, mosaicism of hexanucleotide repeats in C9orf72 does not appear to contribute to the genotypic profile of amyotrophic lateral sclerosis (ALS) (Pamphlett et al. 2013).

In addition to mosaicism within an individual' $\mathrm{s}$ genome, there are well-documented cases of cellular chimeras among dizygotic ('fraternal') twins that happen to be monochorionic. This results from the two chorions fusing because of proximity in the uterus, and it evidently allows blood (and apparently stem cells) to intermingle between the two individuals. This phenomenon is more common in pregnancies that are the product of in vitro fertilization (Williams et al. 2004; Miura and Niikawa 2005). Thus, the rise in frequency of such assisted reproductive technology may have implications for genetic diseases, with regard to both the potential 'partial' manifestation of the phenotype and the complications for genetic screening from a single cell type (which may not manifest the same proportion of chimerism or mosaicism as that occurring in the more relevant cell or tissue type). 


\section{Dividends of molecular technology}

Our understanding of molecular aspects of biology, particularly those relevant to the central dogma, has benefited tremendously from technical advances. The ability to sequence and synthesize polynucleotides, to manipulate DNA sequences in vitro and even in situ, and to precisely quantify specific sequences has allowed advances that could not have been dreamt 60 years ago. And the boon this technology has provided to basic science may be surpassed someday by the benefits to human health provided by the utilization of these methods in translational medicine.

\section{Polymerase chain reaction}

The impact of RNA editing on glutamatergic activity (above) gained considerable heft from a better understanding of the subunit composition of functional receptors, and this was dramatically aided by the ability to analyze the mRNA levels of individual receptor subunits in a single cell. It is difficult to imagine this and a great many other advances, coming to pass without the technological watershed provided by invention of the polymerase chain reaction (PCR). This technique now underlies the state-of-the-art techniques for quantification of mRNA, forensic investigations, several site-specific mutagenesis strategies, the power of laser-capture microscopy, and much of the efficiency of next-generation sequencing (below). In addition to its common utilization in quantitative analysis of RNA levels, the structural constraints of PCR also make it useful for qualitative assessments of polynucleotide structure, such as the relative positions of gene elements or the nature of transcripts and splice variants (Fig. 6).

PCR also serves as one of the murkiest and contentious episodes in the history of scientific discovery. Volumes have been written about this story and its inherent controversies. However, a retrospective such as this has at least some duty to highlight a few historical aspects of the saga. Kary Mullis won the 1993 Nobel Prize in Chemistry for his role in developing PCR, but the team that first reported the concept - 14 years earlier - was led by a 1968 Nobel laureate Har Gobind Khorana. In 1971, Khorana and his postdoc Kjell Kleppe first outlined a strategy for amplifying DNA by cyclical polymerase reactions running off terminal primers (Kleppe et al. 1971); colleagues remember the pair presenting this technique at major scientific conferences of the day. However, the potential utility of this procedure was not realized at the time. In part, this was because of the fact that a new bolus of DNA polymerase had to be resupplied at each cycle of amplification because each cycle requires heating to a relatively high temperature to melt the nascent strands apart and allow access of the primers; this denatured and inactivated the DNA polymerase. Consequently, Kleppe and Khorana only managed a four-fold amplification. Mullis reckoned that this could be extended by several orders of magnitude, and thankfully he was right. He and his colleagues also sold the scientific community on the technique by explicating some of the utilitarian dividends it would reap. In perhaps the earliest report focused on the procedure itself, they explained (or demonstrated) the power of PCR to essentially isolate a sequence from a complex mixture, to attach useful tags such as restriction sites, to analyze RNA via the reverse-transcriptase corollary, and to synthesize relatively large novel sequences entirely 
from synthetic oligonucleotides by stepwise progression of consecutive primers that extended their overlapping 3' ends in cyclical amplifications (Mullis et al. 1986).

Randall Saiki and Henry Erlich, colleagues of Mullis at Cetus Corporation, were keen to apply the technique to one of their primary interests, genotyping of human disease loci. Their first report, a method for diagnosing sickle cell anemia (Saiki et al. 1985), actually made it to press before the initial explanation of PCR cited above. Saiki is also credited by most for the momentous brainchild of using a heat-stable polymerase for PCR (Saiki et al. 1988). It was this innovation that seemed to have captured the imagination of industry, and soon thereafter automated thermocyclers (e.g. US Patent 5616301 ) were being sold to laboratories all over the world, relieving scientists of the drudgery of manually moving tubes between various temperature baths.

In a sense, the advance that allowed PCR to have its profound impact on biological sciences began in the 19th century with Pierre Miquel's reports of 'thermophilic' bacteria that could thrive at $72^{\circ} \mathrm{C}$ (Miquel 1888). Nearly, a century later, Thomas D. Brock and Hudson Freeze reported a new species of thermophilic bacterium which they named Thermus aquaticus (Brock and Freeze 1969). It was this bacterium, discovered in the Lower Geyser Basin of Yellowstone National Park, that Saiki and colleagues would employ to solve the only real limitation of Mullis' s vision. As a key enzyme of a bacterium that could obviously replicate its genome at high temperatures, the T. aquaticus (T.aq.) DNA polymerase was stable at the melting temperature of PCR and thus well suited for application to this procedure.

As mentioned above, one of the earliest major advances that PCR afforded neurochemistry was the ability to determine receptor subunits and channels responsible for the actions of neurotransmitters. This relied on the ambitious vision of Jean Rossier and others who dreamed it might be possible to patch-clamp a neuron, record from it, and then extract the cytosolic contents through the patch pipette for reverse-transcriptase PCR of the cellular RNA (Lambolez et al. 1992). Clues about glutamate receptor distribution, for instance, had been provided a few years earlier through studies by Sakmann and Seeburg, who demonstrated through in situ hybridization that certain receptor subunits, such as 'flip' and 'flop' splice variants were exclusively expressed in single - sometimes adjacent - cells (Sommer et al. 1990). However, a true understanding of the way subunits were combined into a functional receptor required comprehensive determination of all the subunits which were in a cell that exhibited specific conductance properties and ligand specificity. After glutamate receptors, the approach was applied to the subunit composition of GABA and other receptors (Santi et al. 1994). More recently, these efforts benefited from the application of techniques that utilize internal standards to make possible an absolute quantification of the number of individual molecules $( \pm 10$ ) of a given subunit (Tsuzuki et al. 2001)!

\section{DNA sequencing}

Virtually all of molecular biology has been developed in the past 60 years, making a comprehensive discussion of its progress during this period an onerous task. This retrospective has therefore focused primarily on those advancements with a particular relevance to neurochemistry. Nearly, none of this progress could have taken place without the ability to determine the sequence of polynucleotides. But, most biological scientists 
working today have been well schooled in the two traditional, workhorse methods of DNA sequencing: 'Maxam-Gilbert' and 'Sanger'. So, these (generally obsolete) methods will be passed over to devote space to the mind-boggling potential that next-generation sequencing provides via its speed and power.

Next-generation sequencing-A few different modes have been used in the nextgeneration ('next-gen') sequencing boon: sequencing-by-hybridization (SBH), sequencingby-synthesis (SBS), and sequencing-by-ligation. Next-gen SBS is similar to the traditional Sanger method: in that, it actually reports the sequence of a DNA polymerase reaction executed on a primer that is complementary to the template DNA supplied from the 'unknown' sample. In both Sanger and next-gen SBS, only one nucleotide (dATP, dCTP, dGTP, or dTTP) is offered per ligation reaction, and whether or not it is ligated to the primer is determined because of the fact that it is labeled with radioactivity (Sanger only) or fluorescence (utilized by commercial systems currently marketed by Illumina and Roche), or by the reaction' s effect on $\mathrm{pH}$ (utilized by the Ion Torrent system). Although the Sanger method utilizes only one polymerase reaction per strand (and therefore requires much more input DNA), next-gen SBS is reiterative, supplying each nucleotide in successive reactions, creating an ever-growing complementary strand and recording whether or not the nucleotide offered in each round is conjugated or not. Because it utilizes these reiterative cycles, and often involves an initial PCR step to amplify the input DNA, next-gen SBS paradigms can be performed with as little as $50 \mathrm{ng}$ of input DNA. For fluorescence detection, the reiterative cycle format is possible through photobleaching of the fluorescent tag after each polymerase reaction so that each successive round can be assayed against low background. The Ion Torrent system relies on acidification resulting from liberation of a proton when the primer's $3^{\prime}$ hydroxyl executes nucleophilic attack on the a-phosphate of a nucleoside triphosphate. The liberation from a photobleaching step and other issues of sensitivity allow the Torrent to run considerably faster than the light-based sequencers.

SBH approaches have found a solid utility in specialized types of genotyping and are gaining in popularity for more yeoman work as well. The application for which hybridization seems most needed is in the identification of CNVs (above), especially the moderate-to-large regions of the genome that appear to have been duplicated not only during evolution but also during diversification of the human diaspora. Often, these duplications are so large and so similar to the original sequence that they can scarcely be detected by conventional sequencing approaches. Except for heterozygosity that may not be consistent with $2 \mathrm{~N}$ allelic distributions, the results of SBS sequencing are so myopic that they report essentially no difference between the sequence of 200 base pairs in the $\mathrm{p}$ arm of Chromosome 17 and the same sequence within a 1.4-megabase duplicate lying next door in some individuals. SBH - in particular, comparative genomic hybridization arrays - can quantify the number of copies hybridizing to its templates; therefore, it is one of the few techniques that can readily detect CNVs.

RNA-Seq-One of the most powerful dividends of next-gen sequencing is its application to quantitative gene expression analysis. Early strategies for gaining a somewhat comprehensive view of the changes in gene expression across two or more conditions relied 
on burdensome and technically tricky methods such as differential display (Shirvan et al. 1997; Toki et al. 1998; Chen et al. 1999; Liu et al. 1999; Yagita et al. 1999; Yamashita et al. 1999) and subtractive hybridization (Walker and Sevarino 1995; Gould et al. 2000; Leypoldt et al. 2001; Ftouh et al. 2005; Boucquey et al. 2006). Enormous gains in throughput and quantitative accuracy were made when microarray screening was developed (Ang et al. 2001; Chun et al. 2001; Grunblatt et al. 2001; Yoshihara et al. 2002). Nevertheless, arrays must be constructed in advance; they are inherently limited to the 'known universe' of expressed sequences. The human genome is estimated to express protein-encoding mRNA from only about 19000 genes, and microarrays can accommodate as many as 480000 'features' (spots) per microscope slide. It is usually considered necessary to include multiple sequences for each gene, primarily for the sake of confirmation. But, this could be achieved at a level of 25 sequences for each gene on an $8 \times 60000$ microarray.

Nevertheless, next-gen sequencing offers the advantage of potentially pulling novel sequences out of a specimen. And the true beauty is that the sequence is not merely tabbed qualitatively, it can be identified entirely on the basis of a quantitative distinction it exhibits between two treatment groups, between disease and healthy tissue, or indeed between any two (or more) sets of conditions. Use of next-gen sequencing for RNA screening is often called 'RNA- seq', but a somewhat more formal name is 'whole-transcriptome shotgun sequencing'. This technology is somewhat better at quantitation than are microarrays, especially at the high and low ends of the abundance scale. In addition, quantitative comparisons in microarrays are limited by differences in affinity for each target-probe hybrid, a handicap that RNA-seq transcends. It should also be noted that an investigator is dependent upon commercial enterprises or other third parties to select the best probes, and this trust has proved to be misplaced occasionally. Finally, the ability to discover novel splice variants and other modifications should not be overlooked. It has been argued that RNA-seq is uniquely qualified to overcome challenges inherent in analyzing expression patterns in complex human neurological disorders (Sutherland et al. 2011).

Human genome project and HapMap-The political will and financial investment made in sequencing the human genome represents a commitment that rivals the endeavor to put a man on the moon; the payoff may have been even more significant in practical terms. Although much is made of the limitations on understanding the contributions of genes without elucidation of their regulation, discoveries related to the roles that genetic variations play in human biology and disease have been dramatically accelerated by sequencing even a single genome. Almost as important has been the delineation of genetic haplotypes - the various 'Chinese menu' combinations of polymorphisms that predominate in the population - which reached a milestone in 2005 with public release of Phase I of the International HapMap Project (International HapMap Consortium, 2005). This release marked a 'data freeze' that included genotypic information about at least one common single-nucleotide polymorphism (SNP) for every five kilo-bases in all populations under study. The combination of these two undertakings has made possible the tremendous progress of genome-wide association studies (GWAS) and their application to neurological disorders. As inarguably the most complex organ of the body, the brain and its functional auxiliaries is subject to the most complex genetic circumstances of health and disease. GWAS approaches 
are perhaps best suited to discovering quantitative trait loci that summate in 'sporadic' instances of complex diseases such as Alzheimer's disease or bipolar disorder (Baum et al. 2008; Liu et al. 2012a; Lambert et al. 2013), but GWAS are also important for identification of genes that influence age of onset, severity, and rate of progression for diseases known to arise from discrete, highly penetrant genetic loci (Finch et al. 2011; Soler-Lopez et al. 2011; Vass et al. 2011).

There are numerous examples of neurological disorders that have yielded to insights gained from genomic profiling of normal and abnormal brain function (Tsuji 2013). It was traditional genetic analysis that provided mechanistic insights, and the potential for familial screening, regarding Huntington's disease (The Huntington's Disease Collaborative Research Group, 1993). However, next-gen approaches have proved their usefulness with a spate of discoveries. Mutations in over 50 genes have been associated with Charcot-MarieTooth, and at least one, identified through a next-generation (exome-sequencing) approach, had been missed by conventional Sanger sequencing (Landoure et al. 2012). Spinocerebellar ataxia, another condition with marked locus heterogeneity, was also mechanistically unraveled by exome sequencing. Two compound heterozygous mutations in the GLB1 gene were found to confer recessive juvenile-onset GM1 gangliosidosis (Pierson et al. 2012). Of course, the true hope is that genetic understanding can lead to therapeutic innovation. One striking example of the power of genetic discovery comes from the treatment of obesity, a disease we did not even perceive as neurological until we came to understand, largely through basic studies on the molecular physiology and genetics of rodents, that the primary site of action for the satiety hormone leptin is in the hypothalamus (Harvey 2007). Humans with a loss-of-function mutation in leptin, while rare, have benefited tremendously (PazFilho et al. 2011).

\section{Transgenesis}

Perhaps, no other advance in molecular biology has captured the imagination of the layperson like transgenesis, the technical ability to rationally and specifically manipulate the genome of any living thing. The genetic makeup of other species has been manipulated by selective breeding and other aspects of domestication for approximately 20000 years of human history. Experimentalists have occasionally accelerated this process with chemical mutagenesis. However, the power inherent in directing the genetic modification as it is done in transgenic plants and animals obviously renders this objective into another dimension. The lay public immediately comprehends the potential that transgenesis holds for curing genetic diseases or leveraging the efficiency of food production. It is worth noting that a great many inborn errors of metabolism, typically resulting from loss-of-function mutations in an anabolic or catabolic enzyme, manifest as neurological disorders. Thus, the concept of supplying a functional gene through transgenic techniques has particular resonance with those who have a concerned with neurological disease. However, neurochemists and other scientists have probably been just as captivated by the profound impact such genetic modification has as an experimental independent variable for answering difficult biological questions. 
Terminology-The lay press sometimes presumes that 'transgenic' always refers to transspecies insertion of a gene, which it is not, of course. But, scientists are guilty of creating confusion in nomenclature, as well. It seems that one routinely encounters non-standard uses of the term 'knock-in', for instance. Convention dictates that this term be reserved for genetic transfers resulting from homologous recombination, but investigators often use it when working with a randomly inserted transgene if it is combined with knockout of the homolog. The field would be done a great service if all publications and presentations on genetically modified mice were prepared after consultation of standards prepared by the International Committee on Standardized Genetic Nomenclature for Mice (Montoliu and Whitelaw 2011). Nevertheless, there remain substantial differences in the conventions for genetic nomenclature across different species. Today, a great many projects benefit from utilization of multiple models, many transcending entire phyla; thus, it seems that a universal convention for genetic nomenclature might be in order.

Germline transgenics-The earliest germline transgenic animals were created by injection of viral - and later, plasmid - DNA directly into blastocytes or eggs, typically targeting the male pronucleus. A recombination event at this stage enhances the chances that gametes will be included among the cells that incorporate the transgene (though, as a result of the potential for epichro-mosomal replication of concatemerized transgenes, only 20-30\% of founder animals are true mosaics). It also results in a founder that is of a pure strain. The other major approach is stable transfection of a cultured embryonic stem (ES) cell line, followed by injection of the transfectants into a blastocyst. Because the ES cells may or may not differentiate into germ cells in the resulting chimeric mouse, founder lines are somewhat less likely to propagate the transgene. In addition, the vast majority of transgenics produced in this manner rely on ES cells from the Sv129 strain of mice due their efficiency in this application. Introduction of the transgene into another strain - either as the initial blastocyst recipient or through interbreeding of a germline transgenic - creates an animal that is genetically mosaic for more than just the transgene. Though backcrossing to the desired strain for experimentation for six generations is conventionally considered sufficient, even this can permit artifacts; particularly if a phenotypically potent gene is in linkage disequilibrium with the transgene. This and related issues have been highlighted as particularly problematic for neurobehavioral studies (Gerlai 1996). There are a few other approaches to creating germline transgenics, including viral transduction of blastocysts or using sperm as vectors, but these represent a very small fraction of the total lines created.

Knockouts and other instances of homologous recombination-The availability of ES cells has greatly facilitated experimental objectives that require homologous recombination. In straightforward transgenics, the novel gene integrates at site in the genome outside the control of the investigator. However, there are situations in which the genetic modification must be site-specific or 'targeted'. This is a key element of gene ablation, commonly known as 'knockout'. Such targeted deletional mutagenesis is most commonly accomplished by replacing at least part of a gene with a selectable marker such as a drug-resistance gene. This has the practical advantage of allowing enrichment for cells in which integration has taken place, a considerable percentage of which will be correctly 
inserted into the gene of interest via sequences flanking the $\mathrm{NeO}^{\mathrm{R}}$ gene that are homologous to the targeted gene.

In some cases, a more subtle mutation is desired; e.g. a point mutation. In this case, a missense mutation or other small change can be included in the homologous flanking arm of mutagenic construct. It is usually necessary to remove, after the homologous recombination, the selectable marker gene (e.g. $\mathrm{Neo}^{\mathrm{R}}$ ) that intervenes between the mutated homologous flanking arm and the wild-type flanking arm. This is often accomplished via Cre/Lox technology (below), such that a residual of the mutagenesis remains: a single lox $P$ site. If the mutagenic construct is designed such that the selectable marker (and its attendant $l o x P$ sites) is placed in an intron, there should be no significant consequence for the gene's expression or function other than the intended subtle mutation.

A tremendous boon to in situ site-specific mutagenesis has been provided by 'CRISPR' technology (van der Oost 2013; de Souza 2013). The details are too complicated to thoroughly describe here, but this methodology utilizes an RNA guide to seek out a specific position in the chromosomal DNA and target it for attack by an endonuclease (Cas9). The resulting double-stranded break is ligated back together by DNA-repair mechanisms that will usually generate small deletions, resulting in frame-shift mutations that are often deleterious for the targeted gene. Thus, CRISPR is typically used for knockout objectives. However, other types of mutation are possible with the inclusion of a DNA repair template. This construct, introduced along with the guide RNA and Cas9 expression vector, is analogous to the homologous recombination constructs described above; in that, it has two flanking sequences homologous to the gene of interest and straddling the mutation. The latter is incorporated by the naturally occurring, endogenous 'homology-directed repair' system operating on the chromosome following a Cas9 cut. This sort of subtle, site-specific mutation is best accomplished with a slightly modified version of Cas9 that lacks one of its nuclease sites and thereby produces only single-strand breaks; this greatly reduces nonhomologous recombination.

Conditional mutation and inducible expression-A high proportion of neurologically relevant genes cause developmental lethality when ablated. This may be related to the intersection of physiological requirements with important behaviors, such as suckling, and neurological control of other systems, as in the case of respiration. For this and other reasons, it is often desirable to restrict a genetic modification spatially (e.g. to a specific cell type) or temporally (e.g. postnatal). A variety of approaches have been developed for this purpose, applicable to either ablation ('conditional knockout') or overexpression.

Some of the earliest strategies for creating precise control of a genetic modification involved inducible transgenes. A system dependent upon the ecdysone receptor (EcR) was used rather commonly in the late 1990s and was based on supplying a nuclear hormone receptor from insects (actually, a highly engineered derivative of that EcR) along with a transgene whose promoter had a cis element targeted by EcR (No et al. 1996). Expression of the transgene could be induced by administering a synthetic ecdysone to transgenic mice (or cell cultures) carrying both elements. The other major systems used for such inducible expression are 
those utilizing tetracycline-responsive trans-acting factors (Gossen and Bujard 1992; Furth et al. 1994; Gossen et al. 1995); they predated EcR systems by a couple of years and has persisted in more widespread use since. The original approach utilized a tetracycline-binding factor (tTA) that associates with its target DNA element and activates transcription until ligand (a tetracycline, most commonly, doxycycline) is supplied; accordingly, it is termed 'Tet- Off ${ }^{\mathrm{TM}}$ '. Later, mutations were discovered that reversed the actions of tTA such that administration of doxycycline induces the gene in question, creating a system dubbed 'TetOn' ${ }^{\mathrm{TM}}$ ' (Gossen et al. 1995). In all of these systems, the requirement for an auxillary transgene expressing EcR or tTA creates an additional level of control. The timing of expression can be dictated by administration of the chemical inducer or suppressor, and the distribution of expression can be controlled by placing the auxillary transgene under a cell type-specific promoter, such as the CaMKII promoter for expression in forebrain neurons (Engel et al. 2006). Spatial restrictions that are independent of cell type are sometimes effected by injection of a viral vector carrying tTA, for instance, under a universal promoter (Bahi et al. 2005). Of course, when the objective is the reduction of a specific gene product, the inducible transgene can be an RNAi construct (i.e. expressing a short-hairpin RNA) (Bahi et al. 2005).

While inducible expression of RNAi is one means to suppress expression of a gene of interest, it is often more desirable to completely remove the gene in a specific cell type or developmental stage. This is now accomplished most commonly via the Cre/Lox approach, pioneered by Brain Sauer (Sauer and Henderson 1988; Lakso et al. 1992). Like the systems for inducible transgenes (above), Cre/Lox involves transgenic modification not only of the gene of interest but also the introduction of an auxillary protein not present in wild-type eukaryotes: the Cre recombinase, in this case. This enzyme cuts and religates DNA sequences of the loxP motif; when two $10 x P$ sites are placed on either side of a particular chromosomal region (a practice that has come to be called 'floxing') Cre will cut both sites and religate, excising the intervening chromosomal region. It has been demonstrated empirically that this technique can be effective (albeit with somewhat compromised efficiency) for excising DNA stretches as long as two centimorgans $(\sim 4 \mathrm{Mb})$ (Zheng et al. 2000). Just as with EcR and rTA, tissue-specific promoters can restrict expression of Cre spatially and developmentally. In addition, constructs expressing a Cre transgene fused to an estrogen receptor ligand-binding domain $\left(\mathrm{Cre}^{\mathrm{ER}}\right)$ is used to exert temporal control on the Cre activity (Metzger et al. 1995). The modified $\mathrm{Cre}^{\mathrm{ER}}$ enzyme is only active in the presence of an estrogen analog such as tamoxifen. This can be used to overcome one oft-overlooked problem of germline transmission of the Cre: temporary activity arising in a 'cell-typespecific' promoter at unique developmental nodes. A case in point is the expression of glial fibrillary acidic protein in neural stem cells. Driving Cre from a glial fibrillary acidic protein (GFAP) promoter with the intent to restrict a gene excision to astrocytes would be folly unless the $\mathrm{Cre}^{\mathrm{ER}}$ construct is used in conjunction with carefully timed tamoxifen administration.

\section{Viral transduction}

One of the earliest approaches for the manipulation of genes in intact organisms entailed infection with genetically altered viruses. Indeed, one might say that Mother Nature beat us 
to it! There is essentially a continuum of gene transfer evident in the natural history. From the transient infection and expression of virally encoded genes, to retroviruses that insert their genomes into the host's during a lysogenic phase, to retrotransposons that become stabilized and get passed vertically through reproduction, one can say that viral vectors have been shuffling genes around for eons. There are now many reputable studies providing evidence that DNA has been passed between species as disparate as reptiles and mammals for millions of years (Piskurek and Okada 2007; Thomas et al. 2010; Walsh et al. 2013). Thus, it is only natural that scientists and clinicians came to apply this strategy rationally to their métier.

Modified viruses were first used to express foreign genes in mammalian cells in 1976 (Goff and Berg 1976; Nussbaum et al. 1976). A key development was rendering the source virus replication deficient; propagation in cell cultures for the purposes of producing a sufficient titer is achieved with the assistance of a co-infecting 'helper virus' that supplies the missing components of the vector. Although conventional plasmid transfections are very inefficient in non-replicating cells (perhaps due to a need for the nuclear membrane breakdown that mitosis effects), viruses proved quite capable of transducing post-mitotic cells such as neurons. Several viruses with favorable traits for gene transduction also happen to have significant neurotropism. One of the first used for neuroscience studies was an attenuated herpes simplex 1 . Early vectors derived from herpes simplex 1 showed early success in cultured neurons, which they infected readily and directed in the robust expression of important proteins (Geller and Breakefield 1988; Geller et al. 1995; Ho et al. 1995; Fink et al. 1997). But, these vectors were more problematic in vivo, where they suffered frequent inactivation and tended to promote a prohibitively strong immune reaction (Fink and Glorioso 1997). Adenoviruses and adeno-associated viruses (AAV) were being developed concurrently (Fritz et al. 1997; Robert et al. 1997; McFarland et al. 2009), and the latter seem to have surpassed these other first-generation vectors, largely by virtue of their ability to fly under the radar regarding the host immune system (McFarland et al. 2009).

Recombinant AAV (rAAV) vectors are derived from a naturally occurring parvovirus first isolated in 1966 in studies of pathogens in the respiratory tract (Hoggan et al. 1966). Regarding the initial hurdles of making viral vectors replication deficient, AAV almost seems to have been designed for this application, as even in the wild form it is not capable of replicating autonomously (hence its description as an adenovirus-associated virus). But, despite their other favorable properties for neuronal gene expression, rAAVs have a significant limitation on the size of the novel genetic material they can carry - the maximum of foreign DNA is approximately 4.4 kilobases. Lentiviruses and other similar retroviruses can solve this problem, with insertion capacities on the order of 10.5 kilobases. This larger size comes at a cost, however, the infectious particle is also large, and this limits the spread of lentiviruses in tissues somewhat. Moreover, side effects of retroviral vectors are somewhat unpredictable because of their insertion at multiple sites in the genome; destruction of a tumor-suppressor locus or transcriptional activation of an oncogene is quite common, with the potential result being an iatrogenic cancer. It had been thought that rAAV-based vectors were free from this concern, though the native wild-type AAVs are capable of insertion. But, even rAAV vectors are now known to integrate oncogenically at a rate that may be unacceptable (Valdmanis et al. 2012). Considerable hope is placed on the idea that 
nanotechnology may help solve some of the most persistent problems of viral vectors by modifying - perhaps even replacing - viral envelop components with artificial bioactive polymers (Dodds et al. 1999; Shea and Houchin 2004).

\section{Applications}

Experimental implementation-Transgenesis of genes has, of course, made a dramatic impact on empirical biology. The ability to add or remove a gene, or replace it with mutated versions, has meant the world for our understanding of neurochemistry and other subdisciplines. And beyond testing the role of individual proteins, such manipulations have helped to elucidate networks through which genes impact one another in a systemic manner. Indeed, network (or 'pathway') analysis is now a major computational endeavor in expression analysis outputs such as those provided by microarrays and RNA-seq (Crawford et al. 2006; Boulaire et al. 2009; Host et al. 2010; Loke et al. 2013). Nevertheless, some of the dividends of gene shuttling were novel techniques that probably could not have been imagined, much less implemented, prior to the age of transgenesis.

One important innovation has been the use of viral vectors for transsynaptic tracing of neuronal connectivity. Horseradish peroxidase and its conjugates with lectins have been used to trace axon projections since the 1970s (Kristensson et al. 1971; Trojanowski et al. 1981). This technique was even considered as a drug-delivery method for some time (Haschke et al. 1980). The drug in question was an antiviral one, which is somewhat ironic considering that the biggest advance in circuitry tracing in the past decade has used viruses as the tracer. The primary advantage of viral vectors for axonal tracing is the improved capability for transsynaptic propagation. Though wheat-germ-agglutinin and tetanus- or cholera-toxin conjugates of horseradish peroxidase have limited utility as transsynaptic tracers, they dilute quickly and can rarely be used beyond single synapses. Though the strains used are somewhat attenuated, these viruses can replicate; so, they can propagate after they cross a synapse, thus maintaining signal strength. The earliest uses of viruses used more-or-less native pseudorabies virus (PRV) and visualized by immunostaining (Spencer et al. 1990), followed by recombinant PRV containing $\beta$-galactosidase (Loewy et al. 1991). But, the approach gained popularity when sensitivity and versatility were enhanced with the introduction of green-fluorescent protein and its color variants into the viruses (Maskos et al. 2002).

Versatility of this technique is one of its assets. Despite the power of transsynaptic tracing, it is sometimes desirable to restrict the labeling. Restriction to a single cell can be achieved by use of a replication-deficient virus (Wu et al. 2014). And it is even possible to engineer a virus that will stop after crossing just a single synapse (Wickersham et al.2007). The latter is achieved by supplying a missing replication component within only the single original cell (or cell type); this can be provided from another virus or from a specifically expressed transgene (Weible et al. 2010). It is also possible to include or exclude spread through other types of connections, e.g. gap junctions. Many viral tracers will spread via such nonsynaptic sites, but the 'challenge-virus standard'-derived strains of rabies virus and the Bartha strain of PRV, travel only across synapses (Ekstrand et al.2008). In the right hands, viral transsynaptic tracing can reveal novel information about circuitry that has been missed 
by other anatomical approaches. But like so many scientific methods, this technology is also prone to the effect of the observer (McCarthy et al. 2009).

Also benefiting from the transgenic expression of fluorescent proteins is the 'Brainbow' mouse (Livet et al. 2007). This technology utilizes the Cre/Lox system to produce a quasirandom distribution of neurons labeled with different colors of fluorescent proteins. The effect is produced by introducing a compound transgene that contains a coding region (CDS) for green-fluorescent protein, its red variant, its yellow variant, etc., separated by distinct and - this is key - incompatible lox $P$ sites. By placing a compatible partner of each of these $l_{0 x} P$ sites in a small region outside the entire protein coding region, the investigators allow Cre (driven by a neuron-specific promoter) to stochastically choose any compatible pair and thereby excise any intervening fluorescent protein $\operatorname{CDS}(\mathrm{s})$ - and the other $\operatorname{lox} P$ sites - in any given neuron. The recombination event also removes a transcriptional 'Stop' signal blocking the remaining fluorescent protein(s) $\mathrm{CDS}(\mathrm{s})$. Because the other lox $P$ sites have been removed, no other Cre-mediated deletions can occur, locking that cell into its fated color for the rest of its life. More than one fluorescent CDS may remain, however, creating as many as 90 distinguishable combinations!

Similar, but chromatically simpler, approaches are utilized for neuronal fate mapping. A single fluorescent protein reporter gene (mCherry is a favorite) is introduced, again, squelched by a transcriptional block (e.g. a $N e o^{\mathrm{R}}$ coding region followed by robust polyadenylation signals) that is flanked by lox $P$ sites. This can be combined with a Cre construct driven by a promoter specific to a stage in differentiation, such doublecortin (Dcx). If the Cre is also the estrogen-dependent variety ( $\mathrm{Cre}^{\mathrm{ER}}$, above), tamoxifen can be administered in a pulse-chase paradigm to time stamp a population of neurons that were neural stem cells or neuroblasts at the time of tamoxifen treatment. In addition to $D c x$, there are promoters specific to the progenitors of specific neuron subtypes, e.g. $N k x$ and $D l x$ homeodomain genes are transiently expressed in neuroprogenitors giving rise to specific GABAergic interneurons (Fogarty et al. 2007; Taniguchi 2014). The utility of this sort of approach lies in the fact that a marker (e.g. mCherry) can be permanently activated after the transient activation of a developmental- or lineage-specific gene promoter, thus providing versatility that liberates the investigator from a need to find promoters that are active in throughout the life span of a specific cell type.

Light can be used not only to report a cell's location and lineage but also to control neurophysiological activity. 'Optogenetics' is the term most commonly used for technologies that manipulate a neuron's electrophysiological activity via illumination of a light-sensitive, transgenically introduced ion channel. Channelrhodopsin, for instance, is a cation channel discovered in the alga Chlamydomonas reinhardtii. Transgenically expressing it ectopically in specific neurons of an animal allows rather precise regulation of the cell' $\mathrm{s}$ firing rate; it was first used to manipulate animal behavior by Lima and Miesenböck in 2005 (Lima and Miesenbock 2005) and had gained recognition as a revolutionary technology by 2010 (Crick 1999; News Staff, 2010). Optogenetic in mammals was extended by the use (and improvement) of optical fibers to deliver light to deeper brain structures (Aravanis et al. 2007; Sparta et al. 2012; Pisanello et al. 2014). Most recently, the reciprocal relationship 
between 'opto-' and 'genetics' has taken a new twist with the advent of a photoactivatable Cas9 for use in CRISPR applications (Nihongaki et al. 2015).

An alternative to optogenetics is chemogenetics. Research questions that require long-term control or structures that may be vulnerable to the invasive procedures required for delivery of light can be accessed with pharmacology. Intersection of a toxin with transgenic expression of the enzyme that mediates the toxicity - e.g. ganciclovir/thymidine kinase or etronidazole/nitroreductase - has been used for many years to effect a time- and locationspecific elimination of specific cell populations. But, more recently, investigators have been interested in manipulating the electrophysiological activity of specific neuronal populations rather than killing them. 'Designer receptor exclusively activated by designer drugs' and 'receptor activated solely by a synthetic ligand' are terms used in this application. Although optogenetic methods mostly commonly utilize an ion channel as the controllable transgene, Designer receptor exclusively activated by designer drugs/receptor activated solely by a synthetic ligand use metabotropic receptors (Redfern et al. 1999).

Translational implementation-As exciting as a new technical tool may be to the experimentalist, one cannot forget that gene therapy has always been one of the primary objectives of molecular biology.

Despite a great many promising studies in preclinical animal models, gene therapy has yet to make a major impact on human health care. And among the success stories, very few can claim inroads regarding treatment of neurological disorders. As hinted above, lysosomal storage diseases and other inborn errors of metabolism appear to represent one of our best chances for cracking into this difficult therapeutic modality. The very first attempt to apply gene therapy to a lysosomal strorage disease in humans was a viral-vector strategy directed at infantile neuronal ceroid lipofuscinosis, whose victims suffer a loss-of-function mutation of palmitoyl-protein thioesterase 1 (PPTI). An initial attempt to resupply palmitoyl-protein thioesterase with an AAV2 elicited positive outcomes in a few trial participants, but nearly half developed humoral immune responses that mitigated the beneficial effects (Worgall et al. 2008). So, when some of the same investigators joined a team designing a gene therapy trial against mucopolysaccharidosis type IIIA, they incorporated the application of immunosuppressive drugs before and after delivery of the viral gene therapy. In this case, the AAV2-mediated gene delivery seemed to be well tolerated, with only mild reactions being reported. And while the study was not designed to assess efficacy, there were promising trends toward positive outcomes (Tardieu et al. 2014).

A fairly recent study documented a slightly more validated success in metachromatic leukodystrophy by starting early (Biffi et al. 2013). Three toddlers were identified by genetics and biochemical markers to be at risk for were treated prior to clinical symptoms. Autologous stem cell transplants were conducted using hematopoietic stem cells virally transduced ex vivo with a functional gene for arylsulfatase A, the enzyme lacking in this disorder. After returning the stem cells to the participants, high enzyme expression was detected in many hematopoietic lineages and in cerebrospinal fluid of the recipients. At and beyond the age when the participants would have been expected to present with neurological 
symptoms, none were observed. As of April of 2015, an expanded Phase I/II trial had begun with 20 participants.

The antisense RNA work mentioned above (see Post-transcriptional regulation) has been a very useful tool for exploring the roles of individual gene products in a biological system. But, at least one human disease has shown us the promise that such approaches can hold for clinical application. Spinal muscular atrophy (SMA) is a genetic disorder that arises when one copy of the 'survival (of) motor neuron 1' gene (SMN1) suffers a deletion or other lossof-function mutation, leaving lower motor neurons to rely on the backup, SMN2 (Cartegni and Krainer 2002). Although the specific biochemical functions of the SMNs is not entirely clear (they seem to be involved in synthesis and maintenance of small nuclear ribonucleoproteins or snRNPs), they are crucial for the viability of motor neurons. SMN2 differs from SMN1 in a single nucleotide change that reduces the efficiency of an RNA splicing modulation, resulting in far fewer mRNA molecules that contain Exon 7, which in turn generates a predominance of C-terminally truncated protein that consequently has an abbreviated half-life. In 2003, Adrian Krainer and Luca Cartegni showed that it was possible to shift the splicing of SMN2 to include Exon 7 more frequently by introducing a nucleotide-peptide chimeric molecule that would (i) hybridize near the Exon 7 splice acceptor site of SMN2 and (ii) introduce a peptide sequence that would recruit the splice enhancer machinery (Cartegni and Krainer 2003). Later, the Krainer laboratory was able to effect the same outcome with antisense RNAs that mask splicing silencer sequences in two of the SMN2 introns (Hua et al. 2008). Krainer and Kua teamed up with investigators at Genzyme and Ionis (nee Isis) Pharmaceuticals in 2011 to show that these antisense approaches promote survival in a preclinical mouse model of SMA (Passini et al. 2011). Ionis Pharmaceuticals is currently recruiting participants for Phase- 3 clinical trials of similar antisense therapies. This body of work required not only a practical understanding of the SMA disease process but also a detailed understanding of the mechanisms of RNA splicing gleaned from thousands of basic science studies.

\section{The next 60 years...}

The breadth and scope of discovery in the field of molecular neurobiology in a little over half a century is as difficult to grasp as it has been to summarize here. What advances might be accomplished by 2076 can hardly be fathomed, as discoveries tend to open new vistas and reveal new questions and necessities for both technical innovation and conceptual progress. It is predictable, however, that trends we see now will continue in their arc. For instance, the speed, sensitivity, and accuracy of DNA (and RNA) sequencing seems to continue to advance, perhaps in parallel with Moore's law of computational processing. The bioinformatics boon of the past decade may find a fertile field of specialization in 'neuroinformatics' (Amari et al. 2002). A priority has been placed on substantially enhancing our understanding of brain connectivity by policy makers in the US and Europe (Waldrop 2012; Insel et al. 2013); President Obama's BRAIN Initiative has been compared to the Human Genome Project, and they may be related by more than analogy. To the extent that every aspect of biology relies on the structure and expression of genomes, these initiatives must incorporate the tools and concepts of molecular biology to gain their full 
potential. Virally mediated transsynaptic tracing and chemogenetics are just a couple of examples of the assistance gene jockeys can provide to these efforts.

A great deal of hope continues to be placed in the concept of 'personalized medicine'. Implicit in this objective is the individuality in our disease predilections and drug responses conveyed by the distinctions in our genomes. And just as exome analysis of a tumor may provide tailor-made strategies for attacking it, the molecular biology behind each individual case of schizophrenia or autism may be the secret to unlocking successful treatments of persons, vis-àvis 'problems'. Rational drug design already seeks to fashion drugs on the basis of conformationally detailed understanding of their targets; it is reasonable to suppose that this may one day extend to the design of a specific drug for a specific case.

Regardless of where the genes of our brains and the brains of our geneticists take us in the next six decades, there is one likelihood that can be expressed with a great deal of confidence: The Journal of Neurochemistry will be here to celebrate 120 years of disseminating the latest and greatest progress in our field!

\section{Acknowledgements and conflict of interest disclosure}

I appreciate technical and conceptual inputs to Fig. 6 by Deborly Wade. Supported by the National Institutes of Health (R03AG043784). No competing interests to disclose.

\section{Abbreviations used:}

CaMKII

CREB

JNK

LPS

NFKB

NRSF

PKA

REST calcium/calmodulin-activated kinase II

cyclic AMP-responsive element binding

Jun N-terminal kinase

lipopolysaccharide

nuclear factor $\kappa$ light chain enhancer of activated B cells

AKA neuron-restrictive silencer factor

cAMP-activated kinase

RE1-Silencing Transcription factor

\section{References}

Abisambra JF, Jinwal UK, Blair LJ et al. (2013) Tau accumulation activates the unfolded protein response by impairing endoplasmic reticulum-associated degradation. J. Neurosci 33, 9498-9507. [PubMed: 23719816]

Achard CS and Laybutt DR (2012) Lipid-induced endoplasmic reticulum stress in liver cells results in two distinct outcomes: adaptation with enhanced insulin signaling or insulin resistance. Endocrinology 153, 2164-2177. [PubMed: 22374970]

Almeida AM, Murakami Y, Baker A, Maeda Y, Roberts IA, Kinoshita T, Layton DM and Karadimitris A (2007) Targeted therapy for inherited GPI deficiency. N. Engl. J. Med 356, 1641-1647. [PubMed: 17442906] 
Althausen S, Mengesdorf T, Mies G, Olah L, Nairn AC, Proud CG and Paschen W (2001) Changes in the phosphorylation of initiation factor eIF-2alpha, elongation factor eEF-2 and p70 S6 kinase after transient focal cerebral ischaemia in mice. J. Neurochem 78, 779-787. [PubMed: 11520898]

Amari S, Beltrame F, Bjaalie JG et al. (2002) Neuroinformatics: the integration of shared databases and tools towards integrative neuroscience. J. Integr. Neurosci 1, 117-128. [PubMed: 15011281]

Amir RE, Van den Veyver IB, Wan M, Tran CQ, Francke U and Zoghbi HY (1999) Rett syndrome is caused by mutations in X-linked MECP2, encoding methyl-CpG-binding protein 2. Nat. Genet 23, 185-188. [PubMed: 10508514]

Anekonda TS and Reddy PH (2006) Neuronal protection by sirtuins in Alzheimer's disease. J. Neurochem 96, 305-313. [PubMed: 16219030]

Ang E, Chen J, Zagouras P, Magna H, Holland J, Schaeffer E and Nestler EJ (2001) Induction of nuclear factor-kappaB in nucleus accumbens by chronic cocaine administration. J. Neurochem 79, 221-224. [PubMed: 11595774]

Aravanis AM, Wang LP, Zhang F, Meltzer LA, Mogri MZ, Schneider MB and Deisseroth K (2007) An optical neural interface: in vivo control of rodent motor cortex with integrated fiberoptic and optogenetic technology. J. Neural Eng 4, S143-S156. [PubMed: 17873414]

Bahi A, Boyer F, Kolira M and Dreyer JL (2005) In vivo gene silencing of CD81 by lentiviral expression of small interference RNAs suppresses cocaine-induced behaviour. J. Neurochem 92, 1243-1255. [PubMed: 15715673]

Bai G, Zhuang Z, Liu A, Chai Y and Hoffman PW (2003) The role of the RE1 element in activation of the NR1 promoter during neuronal differentiation. J. Neurochem 86, 992-1005. [PubMed: 12887696]

Ballas N, Grunseich C, Lu DD, Speh JC and Mandel G (2005) REST and its corepressors mediate plasticity of neuronal gene chromatin throughout neurogenesis. Cell 121, 645-657. [PubMed: 15907476]

Barger SW, Moerman AM and Mao X (2005) Molecular mechanisms of cytokine-induced neuroprotection: NFkappaB and neuroplasticity. Curr. Pharm. Des 11, 985-998. [PubMed: 15777249]

Barker-Haliski ML, Oldenburger K and Keefe KA (2012) Disruption of subcellular Arc/Arg 3.1 mRNA expression in striatal efferent neurons following partial monoamine loss induced by methamphetamine. J. Neurochem 123, 845-855. [PubMed: 22978492]

Basseri S, Lhotak S, Sharma AM and Austin RC (2009) The chemical chaperone 4-phenylbutyrate inhibits adipogenesis by modulating the unfolded protein response. J. Lipid Res 50, 2486-2501. [PubMed: 19461119]

Baum AE, Hamshere M, Green E, Cichon S, Rietschel M, Noethen MM, Craddock N and McMahon FJ (2008) Meta-analysis of two genome-wide association studies of bipolar disorder reveals important points of agreement. Mol. Psychiatry 13, 466-467. [PubMed: 18421293]

Bayne EH and Allshire RC (2005) RNA-directed transcriptional gene silencing in mammals. Trends Genet. 21, 370-373. [PubMed: 15908035]

Benne R, Van den Burg J, Brakenhoff JP, Sloof P, Van Boom JH and Tromp MC (1986) Major transcript of the frameshifted coxII gene from trypanosome mitochondria contains four nucleotides that are not encoded in the DNA. Cell 46, 819-826. [PubMed: 3019552]

Bernstein P and Ross J (1989) Poly(A), poly(A) binding protein and the regulation of mRNA stability. Trends Biochem. Sci. 14, 373-377. [PubMed: 2688202]

Biffi A, Montini E, Lorioli L et al. (2013) Lentiviral hematopoietic stem cell gene therapy benefits metachromatic leukodystrophy. Science 341, 1233158. [PubMed: 23845948]

Billen D (1968) Methylation of the bacterial chromosome: an event at the "replication point"? J. Mol. Biol 31, 477-486. [PubMed: 4866335]

Boersma MC, Dresselhaus EC, De Biase LM, Mihalas AB, Bergles DE and Meffert MK (2011) A requirement for nuclear factor-kappaB in developmental and plasticity-associated synaptogenesis. J. Neurosci 31, 5414-5425. [PubMed: 21471377]

Boucquey M, De Plaen E, Locker M, Poliard A, Mouillet-Richard S, Boon T and Kellermann O (2006) Noxp20 and Noxp70, two new markers of early neuronal differentiation, detected in 
teratocarcinoma-derived neuroectodermic precursor cells. J. Neurochem 99, 657-669. [PubMed: 17029606]

Boulaire J, Zhao Y and Wang S (2009) Gene expression profiling to define host response to baculoviral transduction in the brain. J. Neurochem 109, 1203-1214. [PubMed: 19476540]

Boutillier AL, Trinh E and Loeffler JP (2003) Selective E2F-dependent gene transcription is controlled by histone deacetylase activity during neuronal apoptosis. J. Neurochem 84, 814-828. [PubMed: 12562525]

Boycott JT and Diver C (1923) On the inheritance of sinistrality in Limnaea peregra. Phil. Trans. Roy. Soc. London B 95, 207-213.

Boycott JT, Diver C, Garstang S and Turner FM (1930) The inheritance of sinistrality in Limnaea peregra. Phil. Trans. Roy. Soc. London B 219, 51-131.

Brandeis M, Frank D, Keshet I, Siegfried Z, Mendelsohn M, Nemes A, Temper V, Razin A and Cedar H (1994) Sp1 elements protect a CpG island from de novo methylation. Nature 371, 435-438. [PubMed: 8090226]

Brock TD and Freeze H (1969) Thermus aquaticus gen. n. and sp. n., a nonsporulating extreme thermophile. J. Bacteriol 98, 289-297. [PubMed: 5781580]

Brodskij VJ and Kusc AA (1962) Izmenenie cisla polyploidnych kletok v postembryonalom razvitiji tkanej krysy. Dokl Akad Nauk SSSR Otd Biol 162, 713-716.

Brostjan C, Anrather J, Csizmadia V, Stroka D, Soares M, Bach FH and Winkler H (1996) Glucocorticoid-mediated repression of NFkappaB activity in endothelial cells does not involve induction of IkappaBalpha synthesis. J. Biol. Chem. 271, 19612-19616. [PubMed: 8702657]

Bruce-Keller AJ, Barger SW, Moss NI, Pham JT, Keller JN and Nath A (2001) Pro-inflammatory and pro-oxidant properties of the HIV protein Tat in a microglial cell line: attenuation by 17 betaestradiol. J. Neurochem 78, 1315-1324. [PubMed: 11579140]

Burns MP, Vardanian L, Pajoohesh-Ganji A, Wang L, Cooper M, Harris DC, Duff K and Rebeck GW (2006) The effects of ABCA1 on cholesterol efflux and Abeta levels in vitro and in vivo. J. Neurochem 98, 792-800. [PubMed: 16771834]

Cahill AL and Perlman RL (1991) Activation of a microtubule-associated protein-2 kinase by insulinlike growth factor-I in bovine chromaffin cells. J. Neurochem 57, 1832-1839. [PubMed: 1658224]

Cao M, Cortes M, Moore CS et al. (2015) Fetal microglial phenotype in vitro carries memory of prior in vivo exposure to inflammation. Front. Cell. Neurosci 9, 294. [PubMed: 26300730]

Cardenas A, Moro MA, Hurtado O, Leza JC, Lorenzo P, Castrillo A, Bodelon OG, Bosca L and Lizasoain I (2000) Implication of glutamate in the expression of inducible nitric oxide synthase after oxygen and glucose deprivation in rat forebrain slices. J. Neurochem 74, 2041-2048. [PubMed: 10800947]

Carpentier R, Sacchetti P, Segard P, Staels B and Lefebvre P (2008) The glucocorticoid receptor is a co-regulator of the orphan nuclear receptor Nurr1. J. Neurochem 104, 777-789. [PubMed: 17986226]

Cartegni L and Krainer AR (2002) Disruption of an SF2/ASF-dependent exonic splicing enhancer in SMN2 causes spinal muscular atrophy in the absence of SMN1. Nat. Genet 30, 377-384. [PubMed: 11925564]

Cartegni L and Krainer AR (2003) Correction of disease-associated exon skipping by synthetic exonspecific activators. Nat. Struct. Biol 10, 120-125. [PubMed: 12524529]

Chang RC, Suen KC, Ma CH, Elyaman W, Ng HK and Hugon J (2002) Involvement of doublestranded RNA-dependent protein kinase and phosphorylation of eukaryotic initiation factor-2alpha in neuronal degeneration. J. Neurochem 83, 1215-1225. [PubMed: 12437593]

Chen J and Berry MJ (2003) Selenium and selenoproteins in the brain and brain diseases. J. Neurochem. 86, 1-12. [PubMed: 12807419]

Chen J, Nye HE, Kelz MB, Hiroi N, Nakabeppu Y, Hope BT and Nestler EJ (1995) Regulation of delta FosB and FosB-like proteins by electroconvulsive seizure and cocaine treatments. Mol. Pharmacol 48, 880-889. [PubMed: 7476919]

Chen J, Kelz MB, Hope BT, Nakabeppu Y and Nestler EJ (1997) Chronic Fos-related antigens: stable variants of deltaFosB induced in brain by chronic treatments. J. Neurosci 17, 4933-4941. [PubMed: 9185531] 
Chen G, Zeng WZ, Yuan PX, Huang LD, Jiang YM, Zhao ZH and Manji HK (1999) The moodstabilizing agents lithium and valproate robustly increase the levels of the neuroprotective protein bcl-2 in the CNS. J. Neurochem 72, 879-882. [PubMed: 9930766]

Chen D, Jin K, Kawaguchi K et al. (2003) Ero1-L, an ischemia-inducible gene from rat brain with homology to global ischemia-induced gene 11 (Giig11), is localized to neuronal dendrites by a dispersed identifier (ID) element-dependent mechanism. J. Neurochem 85, 670-679. [PubMed: 12694393]

Cheung WM, Chu AH and Ip NY (1997) Identification of candidate genes induced by retinoic acid in embryonal carcinoma cells. J. Neurochem 68, 1882-1888. [PubMed: 9109513]

Chun HS, Gibson GE, DeGiorgio LA, Zhang H, Kidd VJ and Son JH (2001) Dopaminergic cell death induced by MPP(+), oxidant and specific neurotoxicants shares the common molecular mechanism. J. Neurochem 76, 1010-1021. [PubMed: 11181820]

Cidad P, Garcia-Nogales P, Almeida A and Bolanos JP (2001) Expression of glucose transporter GLUT3 by endotoxin in cultured rat astrocytes: the role of nitric oxide. J. Neurochem 79, 17-24. [PubMed: 11595753]

Coggeshall RE, Yaksta BA and Swartz FJ (1970) A cytophotometric analysis of the DNA in the nucleus of the giant cell, R-2, in Aplysia. Chromosoma 32, 205-212. [PubMed: 5534925]

Condorelli DF, Dell'Albani P, Aronica E, Genazzani AA, Casabona G, Corsaro M, Balazs R and Nicoletti F (1993) Growth conditions differentially regulate the expression of alpha-amino-3hydroxy-5-methylisoxazole-4-propionate (AMPA) receptor subunits in cultured neurons. J. Neurochem 61, 2133-2139. [PubMed: 7504083]

Cone JE, Del Rio RM, Davis JN and Stadtman TC (1976) Chemical characterization of the selenoprotein component of clostridial glycine reductase: identification of selenocysteine as the organoselenium moiety. Proc. Natl Acad. Sci. USA 73, 2659-2663. [PubMed: 1066676]

Conforti P, Zuccato C, Gaudenzi G, Ieraci A, Camnasio S, Buckley NJ, Mutti C, Cotelli F, Contini A and Cattaneo E (2013) Binding of the repressor complex REST-mSIN3b by small molecules restores neuronal gene transcription in Huntington's disease models. J. Neurochem 127, 22-35. [PubMed: 23800350]

Conti F, Minelli A, Molnar M and Brecha NC (1994) Cellular localization and laminar distribution of NMDAR1 mRNA in the rat cerebral cortex. J. Comp. Neurol 343, 554-565. [PubMed: 8034787]

Cragle FK and Baldini G (2014) Mild lipid stress induces profound loss of MC4R protein abundance and function. Mol. Endocrinol 28, 357-367. [PubMed: 24506538]

Cramer PE, Cirrito JR, Wesson DW et al. (2012) ApoE-directed therapeutics rapidly clear betaamyloid and reverse deficits in AD mouse models. Science 335, 1503-1506. [PubMed: 22323736]

Crawford FC, Wood ML, Wilson SE, Mathura VS, Hollen TR, Geall F, Kolippakkam DN and Mullan MJ (2006) Cocaine induced inflammatory response in human neuronal progenitor cells. J. Neurochem 97, 662-674. [PubMed: 16539665]

Crick F (1999) The impact of molecular biology on neuroscience. Philos. Trans. R. Soc. Lond. B Biol. Sci 354, 2021-2025. [PubMed: 10670022]

Dash PK, Karl KA, Colicos MA, Prywes R and Kandel ER (1991) cAMP response element-binding protein is activated by $\mathrm{Ca}^{2+} /$ calmodulin-as well as cAMP-dependent protein kinase. Proc. Natl Acad. Sci. USA 88, 5061-5065. [PubMed: 1647024]

Davis L, Banker GA and Steward O (1987) Selective dendritic transport of RNA in hippocampal neurons in culture. Nature 330, 477-479. [PubMed: 2446139]

DeGracia DJ, Neumar RW, White BC and Krause GS (1996) Global brain ischemia and reperfusion: modifications in eukaryotic initiation factors associated with inhibition of translation initiation. J. Neurochem 67, 2005-2012. [PubMed: 8863507]

Derijard B, Hibi M, Wu IH, Barrett T, Su B, Deng T, Karin M and Davis RJ (1994) JNK1: a protein kinase stimulated by UV light and Ha-Ras that binds and phosphorylates the c-Jun activation domain. Cell 76, 1025-1037. [PubMed: 8137421]

Ding H, Dolan PJ and Johnson GV (2008) Histone deacetylase 6 interacts with the microtubuleassociated protein tau. J. Neurochem 106, 2119-2130. [PubMed: 18636984] 
Dodds E, Piper TA, Murphy SJ and Dickson G (1999) Cationic lipids and polymers are able to enhance adenoviral infection of cultured mouse myotubes. J. Neurochem. 72, 2105-2112. [PubMed: 10217291]

Dodel RC, Du Y, Bales KR, Gao F and Paul SM (1999) Sodium salicylate and 17beta-estradiol attenuate nuclear transcription factor NF-kappaB translocation in cultured rat astroglial cultures following exposure to amyloid A beta(1-40) and lipopolysaccharides. J. Neurochem 73, 1453 1460. [PubMed: 10501189]

Drew PD, Lonergan M, Goldstein ME, Lampson LA, Ozato K and McFarlin DE (1993) Regulation of MHC class I and beta 2-microglobulin gene expression in human neuronal cells. Factor binding to conserved cis-acting regulatory sequences correlates with expression of the genes. J. Immunol 150, 3300-3310. [PubMed: 8468472]

Duning K, Buck F, Barnekow A and Kremerskothen J (2008) SYNCRIP, a component of dendritically localized mRNPs, binds to the translation regulator BC200 RNA. J. Neurochem 105, 351-359. [PubMed: 18045242]

Dvoriantchikova G and Ivanov D (2014) Tumor necrosis factor-alpha mediates activation of NFkappaB and JNK signaling cascades in retinal ganglion cells and astrocytes in opposite ways. Eur. J. Neurosci 40, 3171-3178. [PubMed: 25160799]

Eberwine J, Miyashiro K, Kacharmina JE and Job C (2001) Local translation of classes of mRNAs that are targeted to neuronal dendrites. Proc. Natl Acad. Sci. USA 98, 7080-7085. [PubMed: 11416191]

Ekstrand MI, Enquist LW and Pomeranz LE (2008) The alpha-herpesviruses: molecular pathfinders in nervous system circuits. Trends Mol. Med 14, 134-140. [PubMed: 18280208]

Elbashir SM, Lendeckel W and Tuschl T (2001) RNA interference is mediated by 21-and 22nucleotide RNAs. Genes Dev 15, 188-200. [PubMed: 11157775]

Engel T, Goni-Oliver P, Lucas JJ, Avila J and Hernandez F (2006) Chronic lithium administration to FTDP-17 tau and GSK-3beta overexpressing mice prevents tau hyperphosphorylation and neurofibrillary tangle formation, but pre-formed neurofibrillary tangles do not revert. J. Neurochem 99, 1445-1455. [PubMed: 17059563]

Faigle R, Liu L, Cundiff P, Funa K and Xia Z (2008) Opposing effects of retinoid signaling on astrogliogenesis in embryonic day 13 and 17 cortical progenitor cells. J. Neurochem 106, 16811698. [PubMed: 18564368]

Feinstein DL (2016) Causes, consequences and cures in the regulation of neuroinflammation by noradrenaline in the Locus coeruleus. J. Neurochem 139(Suppl. 2), 154-178. [PubMed: 26968403]

Feng Y, Liu T, Dong SY, Guo YJ, Jankovic J, Xu H and Wu YC (2015) Rotenone affects p53 transcriptional activity and apoptosis via targeting SIRT1 and H3K9 acetylation in SH-SY5Y cells. J. Neurochem 134, 668-676. [PubMed: 25991017]

Finch N, Carrasquillo MM, Baker M et al. (2011) TMEM106B regulates progranulin levels and the penetrance of FTLD in GRN mutation carriers. Neurology 76, 467-474. [PubMed: 21178100]

Fink DJ and Glorioso JC (1997) Engineering herpes simplex virus vectors for gene transfer to neurons. Nat. Med 3, 357-359. [PubMed: 9055868]

Fink SL, Chang LK, Ho DY and Sapolsky RM (1997) Defective herpes simplex virus vectors expressing the rat brain stress-inducible heat shock protein 72 protect cultured neurons from severe heat shock. J. Neurochem 68, 961-969. [PubMed: 9048741]

Fire A, Xu S, Montgomery MK, Kostas SA, Driver SE and Mello CC(1998) Potent and specific genetic interference by double-stranded RNA in Caenorhabditis elegans. Nature 391, 806-811. [PubMed: 9486653]

Fogarty M, Grist M, Gelman D, Marin O, Pachnis V and Kessaris N (2007) Spatial genetic patterning of the embryonic neuroepithelium generates GABAergic interneuron diversity in the adult cortex. J. Neurosci 27, 10935-10946. [PubMed: 17928435]

Forgione N and Tropepe V (2012) Toll-like signaling and the cytokine IL-6 regulate histone deacetylase dependent neuronal survival. PLoS ONE 7, e41033. [PubMed: 22848425]

Frade JM and Lopez-Sanchez N (2010) A novel hypothesis for Alzheimer disease based on neuronal tetraploidy induced by p75 (NTR). Cell Cycle 9, 1934-1941. [PubMed: 20436277] 
Fritz JD, Utz AL, Hale NM, Wu L, Powers AC, Verdoorn TA and Robertson D (1997) Gene-based neurotransmitter modulation in cerebellar granule neurons. J. Neurochem 68, 204-212. [PubMed: 8978727]

Ftouh S, Akbar MT, Hirsch SR and de Belleroche JS (2005) Down-regulation of Dickkopf 3, a regulator of the Wnt signalling pathway, in elderly schizophrenic subjects. J. Neurochem 94, 520530. [PubMed: 15998302]

Fujiyoshi M, Ohtsuki S, Hori S, Tachikawa M and Terasaki T (2007) 24S-hydroxycholesterol induces cholesterol release from choroid plexus epithelial cells in an apical-and apoE isoform-dependent manner concomitantly with the induction of ABCA1 and ABCG1 expression. J. Neurochem 100, 968-978. [PubMed: 17101031]

Fukuchi M and Tsuda M (2010) Involvement of the $3^{\prime}$-untranslated region of the brain-derived neurotrophic factor gene in activity-dependent mRNA stabilization. J. Neurochem 115, 12221233. [PubMed: 20874756]

Fukuchi M, Kirikoshi Y, Mori A, Eda R, Ihara D, Takasaki I, Tabuchi A and Tsuda M (2014) Excitatory GABA induces BDNF transcription via CRTC1 and phosphorylated CREB-related pathways in immature cortical cells. J. Neurochem 131, 134-146. [PubMed: 24965890]

Furth PA, St Onge L, Boger H, Gruss P, Gossen M, Kistner A, Bujard H and Hennighausen L (1994) Temporal control of gene expression in transgenic mice by a tetracycline-responsive promoter. Proc. Natl Acad. Sci. USA 91, 9302-9306. [PubMed: 7937760]

Garcia Del Cano G, Aretxabala X, Gonzalez-Burguera I, Montana M, Lopez de Jesus M, Barrondo S, Barrio RJ, Sampedro C, Goicolea MA and Salles J (2014) Nuclear diacylglycerol lipase-alpha in rat brain cortical neurons: evidence of 2-arachidonoylglycerol production in concert with phospholipase C-beta activity. J. Neurochem 132, 489-503. [PubMed: 25308538]

Garcia-Nogales P, Almeida A, Fernandez E, Medina JM and Bolanos JP (1999) Induction of glucose-6-phosphate dehydrogenase by lipopolysaccharide contributes to preventing nitric oxidemediated glutathione depletion in cultured rat astrocytes. J. Neurochem 72, 1750-1758. [PubMed: 10098886]

Gay S and Foiani M (2015) Nuclear envelope and chromatin, lock and key of genome integrity. Int. Rev. Cell Mol. Biol 317, 267-330. [PubMed: 26008788]

Geller AI and Breakefield XO (1988) A defective HSV-1 vector expresses Escherichia coli betagalactosidase in cultured peripheral neurons. Science 241, 1667-1669. [PubMed: 2843986]

Geller AI, During MJ, Oh YJ, Freese A and O'Malley K (1995) An HSV-1 vector expressing tyrosine hydroxylase causes production and release of L-dopa from cultured rat striatal cells. J. Neurochem 64, 487-496. [PubMed: 7830040]

Gerlai R (1996) Gene-targeting studies of mammalian behavior: is it the mutation or the background genotype? Trends Neurosci 19, 177-181. [PubMed: 8723200]

Giatti S, Boraso M, Melcangi RC and Viviani B (2012) Neuroactive steroids, their metabolites, and neuroinflammation. J. Mol. Endocrinol 49, R125-R134. [PubMed: 22966132]

Gobert D, Topolnik L, Azzi M, Huang L, Badeaux F, Desgroseillers L, Sossin WS and Lacaille JC (2008) Forskolin induction of late-LTP and up-regulation of $5^{\prime}$ TOP mRNAs translation via mTOR, ERK, and PI3K in hippocampal pyramidal cells. J. Neurochem 106, 1160-1174. [PubMed: 18466337]

Goff SP and Berg P (1976) Construction of hybrid viruses containing SV40 and lambda phage DNA segments and their propagation in cultured monkey cells. Cell 9, 695-705. [PubMed: 189942]

Gossen M and Bujard H (1992) Tight control of gene expression in mammalian cells by tetracyclineresponsive promoters. Proc. Natl Acad. Sci. USA 89, 5547-5551. [PubMed: 1319065]

Gossen M, Freundlieb S, Bender G, Muller G, Hillen W and Bujard H (1995) Transcriptional activation by tetracyclines in mammalian cells. Science 268, 1766-1769. [PubMed: 7792603]

Gould RM, Freund CM, Palmer F and Feinstein DL (2000) Messenger RNAs located in myelin sheath assembly sites. J. Neurochem 75, 1834-1844. [PubMed: 11032872]

Greig A, Donevan SD, Mujtaba TJ, Parks TN and Rao MS (2000) Characterization of the AMPAactivated receptors present on motoneurons. J. Neurochem 74, 179-191. [PubMed: 10617119]

Gruber CJ, Tschugguel W, Schneeberger C and Huber JC (2002) Production and actions of estrogens. N. Engl. J. Med. 346, 340-352. [PubMed: 11821512] 
Grunblatt E, Mandel S, Maor G and Youdim MB (2001) Gene expression analysis in N-methyl-4phenyl-1,2,3,6-tetrahydropyridine mice model of Parkinson's disease using cDNA microarray: effect of R-apomorphine. J. Neurochem 78, 1-12.

Grunstein M (1990) Histone function in transcription. Annu. Rev. Cell Biol 6, 643-678. [PubMed: 2275823]

Guil S and Esteller M (2009) DNA methylomes, histone codes and miRNAs: tying it all together. Int. J. Biochem. Cell Biol 41, 87-95. [PubMed: 18834952]

Gupta S, Kim SY, Artis S, Molfese DL, Schumacher A, Sweatt JD, Paylor RE and Lubin FD (2010) Histone methylation regulates memory formation. J. Neurosci 30, 3589-3599. [PubMed: 20219993]

Hamilton AJ and Baulcombe DC (1999) A species of small antisense RNA in posttranscriptional gene silencing in plants. Science 286, 950-952. [PubMed: 10542148]

Hammond SM, Bernstein E, Beach D and Hannon GJ (2000) An RNA-directed nuclease mediates post-transcriptional gene silencing in Drosophila cells. Nature 404, 293-296. [PubMed: 10749213]

Han M, Chang M, Kim UJ and Grunstein M (1987) Histone H2B repression causes cell-cycle-specific arrest in yeast: effects on chromosomal segregation, replication, and transcription. Cell 48, 589597. [PubMed: 3815518]

Han J, Murthy R, Wood B, Song B, Wang S, Sun B, Malhi H and Kaufman RJ (2013) ER stress signalling through eIF2alpha and CHOP, but not IRE1alpha, attenuates adipogenesis in mice. Diabetologia 56, 911-924. [PubMed: 23314846]

Hansen TV, Rehfeld JF and Nielsen FC (2004) KCl and forskolin synergistically up-regulate cholecystokinin gene expression via coordinate activation of CREB and the co-activator CBP. J. Neurochem 89, 15-23. [PubMed: 15030385]

Harant H, Wolff B and Lindley IJ (1998) 1Alpha,25-dihydroxyvitamin D3 decreases DNA binding of nuclear factor-kappaB in human fibroblasts. FEBS Lett 436, 329-334. [PubMed: 9801142]

Harding HP, Zhang Y and Ron D (1999) Protein translation and folding are coupled by an endoplasmic-reticulum-resident kinase. Nature 397, 271-274. [PubMed: 9930704]

Harvey J (2007) Leptin: a diverse regulator of neuronal function. J. Neurochem 100, 307-313. [PubMed: 17076761]

Haschke RH, Ordronneau JM and Bunt AH (1980) Preparation and retrograde axonal transport of an antiviral drug/horseradish peroxidase conjugate. J. Neurochem 35, 1431-1435. [PubMed: 6160208]

Hashida H, Goto J, Kurisaki H, Mizusawa H and Kanazawa I (1997) Brain regional differences in the expansion of a CAG repeat in the spinocerebellar ataxias: dentatorubral-pallidoluysian atrophy, Machado-Joseph disease, and spinocerebellar ataxia type 1. Ann. Neurol 41, 505-511. [PubMed: 9124808]

Herman CJ and Lapham LW (1968) DNA content of neurons in the cat hippocampus. Science 160, 537. [PubMed: 5644058]

Hidaka S, Yoshimatsu H, Kondou S et al. (2001) Hypoleptinemia, but not hypoinsulinemia, induces hyperphagia in streptozotocin-induced diabetic rats. J. Neurochem 77, 993-1000. [PubMed: 11359864]

Higuchi M, Single FN, Kohler M, Sommer B, Sprengel R and Seeburg PH (1993) RNA editing of AMPA receptor subunit GluR-B: a base-paired intron-exon structure determines position and efficiency. Cell 75, 1361-1370. [PubMed: 8269514]

Ho DY, Saydam TC, Fink SL, Lawrence MS and Sapolsky RM (1995) Defective herpes simplex virus vectors expressing the rat brain glucose transporter protect cultured neurons from necrotic insults. J. Neurochem 65, 842-850. [PubMed: 7616244]

Hoggan MD, Blacklow NR and Rowe WP (1966) Studies of small DNA viruses found in various adenovirus preparations: physical, biological, and immunological characteristics. Proc. Natl Acad. Sci. USA 55, 1467-1474. [PubMed: 5227666]

Hollmann M, Hartley M and Heinemann S (1991) $\mathrm{Ca}^{2+}$ permeability of KA-AMPA-gated glutamate receptor channels depends on subunit composition. Science 252, 851-853. [PubMed: 1709304] 
Holtz WA, Turetzky JM, Jong YJ and O’Malley KL (2006) Oxidative stress-triggered unfolded protein response is upstream of intrinsic cell death evoked by parkinsonian mimetics. J. Neurochem 99, 54-69. [PubMed: 16987235]

Horvath S (2013) DNA methylation age of human tissues and cell types. Genome Biol 14, R115. [PubMed: 24138928]

Hosoi T, Matsuzaki S, Miyahara T, Shimizu K, Hasegawa Y and Ozawa K (2015) Possible involvement of 15-deoxy-Delta(12,14) -prostaglandin $\mathrm{J} 2$ in the development of leptin resistance. J. Neurochem 133, 343-351. [PubMed: 25662180]

Host L, Anglard P, Romieu P, Thibault C, Dembele D, Aunis D and Zwiller J (2010) Inhibition of histone deacetylases in rats self-administering cocaine regulates lissencephaly gene-1 and reelin gene expression, as revealed by microarray technique. J. Neurochem 113, 236-247. [PubMed: 20132486]

Hsieh J, Nakashima K, Kuwabara T, Mejia E and Gage FH (2004) Histone deacetylase inhibitionmediated neuronal differentiation of multipotent adult neural progenitor cells. Proc. Natl Acad. Sci. USA 101, 16659-16664. [PubMed: 15537713]

Hu J and Connor JR (1996) Demonstration and characterization of the iron regulatory protein in human brain. J. Neurochem 67, 838-844. [PubMed: 8764614]

$\mathrm{Hu}$ X, Li S, Wu J, Xia C and Lala DS (2003) Liver X receptors interact with corepressors to regulate gene expression. Mol Endocrinol 17, 1019-1026. [PubMed: 12663743]

Hu X, Nesic-Taylor O, Qiu J, Rea HC, Fabian R, Rassin DK and Perez-Polo JR (2005) Activation of nuclear factor-kappaB signaling pathway by interleukin-1 after hypoxia/ischemia in neonatal rat hippocampus and cortex. J. Neurochem 93, 26-37. [PubMed: 15773902]

Hua Y, Vickers TA, Okunola HL, Bennett CF and Krainer AR (2008) Antisense masking of an hnRNP A1/A2 intronic splicing silencer corrects SMN2 splicing in transgenic mice. Am. J. Hum. Genet 82, 834-848. [PubMed: 18371932]

Huang CC, Lee CC and Hsu KS (2004) An investigation into signal transduction mechanisms involved in insulin-induced long-term depression in the CA1 region of the hippocampus. J. Neurochem. 89, 217-231. [PubMed: 15030406]

Hunt SP, Pini A and Evan G (1987) Induction of c-fos-like protein in spinal cord neurons following sensory stimulation. Nature 328, 632-634. [PubMed: 3112583]

Imielski Y, Schwamborn JC, Luningschror P et al. (2012) Regrowing the adult brain: NF-kappaB controls functional circuit formation and tissue homeostasis in the dentate gyrus. PLoS ONE 7, e30838. [PubMed: 22312433]

Insel TR, Landis SC and Collins FS (2013) Research priorities. The NIH BRAIN Initiative. Science 340, 687-688. [PubMed: 23661744]

International HapMap Consortium (2005) A haplotype map of the human genome. Nature 437, 12991320. [PubMed: 16255080]

Iourov IY, Vorsanova SG, Liehr T and Yurov YB (2009) Aneuploidy in the normal, Alzheimer's disease and ataxia-telangiectasia brain: differential expression and pathological meaning. Neurobiol. Dis 34, 212-220. [PubMed: 19344645]

Ishihara T, Akiyama K, Kashihara K, Ujike H, Hamamura T, Okada S and Kuroda S (1996) Activator protein-1 binding activities in discrete regions of rat brain after acute and chronic administration of methamphetamine. J. Neurochem 67, 708-716. [PubMed: 8764599]

Ishizuka Y, Kakiya N, Witters LA, Oshiro N, Shirao T, Nawa H and Takei N (2013) AMP-activated protein kinase counteracts brain-derived neurotrophic factor-induced mammalian target of rapamycin complex 1 signaling in neurons. J. Neurochem 127, 66-77. [PubMed: 23841933]

Ito Y, Tanaka F, Yamamoto M, Doyu M, Nagamatsu M, Riku S, Mitsuma T and Sobue G (1998) Somatic mosaicism of the expanded CAG trinucleotide repeat in mRNAs for the responsible gene of Machado-Joseph disease (MJD), dentatorubral-pallidoluysian atrophy (DRPLA), and spinal and bulbar muscular atrophy (SBMA). Neurochem. Res 23, 25-32. [PubMed: 9482263]

Izant JG and Weintraub H (1984) Inhibition of thymidine kinase gene expression by anti-sense RNA: a molecular approach to genetic analysis. Cell 36, 1007-1015. [PubMed: 6323013]

Janke A and Paabo S (1993) Editing of a tRNA anticodon in marsupial mitochondria changes its codon recognition. Nucleic Acids Res 21, 1523-1525. [PubMed: 8479901] 
Jarosinski KW, Whitney LW and Massa PT (2001) Specific deficiency in nuclear factor-kB activation in neurons of the central nervous system. Lab. Invest 81, 1275-1288. [PubMed: 11555675]

Jenuwein T and Allis CD (2001) Translating the histone code. Science 293, 1074-1080. [PubMed: 11498575]

Jimenez CR, Eyman M, Lavina ZS, Gioio A, Li KW, van der Schors RC, Geraerts WP, Giuditta A, Kaplan BB and van Minnen J (2002) Protein synthesis in synaptosomes: a proteomics analysis. J. Neurochem 81, 735-744. [PubMed: 12065633]

Johnson SC, Rabinovitch PS and Kaeberlein M (2013) mTOR is a key modulator of ageing and agerelated disease. Nature 493, 338-345. [PubMed: 23325216]

Jones PA (2012) Functions of DNA methylation: islands, start sites, gene bodies and beyond. Nat. Rev. Genet 13, 484-492. [PubMed: 22641018]

Jurkin J, Henkel T, Nielsen AF, Minnich M, Popow J, Kaufmann T, Heindl K, Hoffmann T, Busslinger M and Martinez J (2014) The mammalian tRNA ligase complex mediates splicing of XBP1 mRNA and controls antibody secretion in plasma cells. EMBO J 33, 2922-2936. [PubMed: 25378478]

Kalousek F and Morris NR (1969) Deoxyribonucleic acid methylase activity in pea seedlings. Science 164, 721-722. [PubMed: 5778022]

Kappler JW (1970) The kinetics of DNA methylation in cultures of a mouse adrenal cell line. J. Cell. Physiol 75, 21-31. [PubMed: 4392119]

Kapranov P, Cheng J, Dike S et al. (2007) RNA maps reveal new RNA classes and a possible function for pervasive transcription. Science 316, 1484-1488. [PubMed: 17510325]

Karaskov E, Scott C, Zhang L, Teodoro T, Ravazzola M and Volchuk A(2006) Chronic palmitate but not oleate exposure induces endoplasmic reticulum stress, which may contribute to INS-1 pancreatic beta-cell apoptosis. Endocrinology 147, 3398-3407. [PubMed: 16601139]

Kawahara Y, Kwak S, Sun H, Ito K, Hashida H, Aizawa H, Jeong SY and Kanazawa I (2003) Human spinal motoneurons express low relative abundance of GluR2 mRNA: an implication for excitotoxicity in ALS. J. Neurochem 85, 680-689. [PubMed: 12694394]

Kawasaki N, Asada R, Saito A, Kanemoto S and Imaizumi K (2012) Obesity-induced endoplasmic reticulum stress causes chronic inflammation in adipose tissue. Sci. Rep 2, 799. [PubMed: 23150771]

Keleshian VL, Modi HR, Rapoport SI and Rao JS (2013) Aging is associated with altered inflammatory, arachidonic acid cascade, and synaptic markers, influenced by epigenetic modifications, in the human frontal cortex. J. Neurochem 125, 63-73. [PubMed: 23336521]

Kharroubi I, Ladriere L, Cardozo AK, Dogusan Z, Cnop M and Eizirik DL (2004) Free fatty acids and cytokines induce pancreatic beta-cell apoptosis by different mechanisms: role of nuclear factorkappaB and endoplasmic reticulum stress. Endocrinology 145, 5087-5096. [PubMed: 15297438]

Kim Y, Park M, Boghossian S and York DA (2010) Three weeks voluntary running wheel exercise increases endoplasmic reticulum stress in the brain of mice. Brain Res 1317, 13-23. [PubMed: 20045396]

Klann E, Roberson ED, Knapp LT and Sweatt JD (1998) A role for superoxide in protein kinase C activation and induction of long-term potentiation. J. Biol. Chem 273, 4516-4522. [PubMed: 9468506]

Kleiman R, Banker G and Steward O (1990) Differential subcellular localization of particular mRNAs in hippocampal neurons in culture. Neuron 5, 821-830. [PubMed: 2148488]

Kleppe K, Ohtsuka E, Kleppe R, Molineux I and Khorana HG (1971) Studies on polynucleotides. XCVI. Repair replications of short synthetic DNA's as catalyzed by DNA polymerases. J. Mol. Biol 56, 341-361. [PubMed: 4927950]

Klopstock T, Chahrokh-Zadeh S, Holinski-Feder E, Meindl A, Gasser T, Pongratz D and Muller-Felber W (1999) Markedly different course of Friedreich' s ataxia in sib pairs with similar GAA repeat expansions in the frataxin gene. Acta Neuropathol 97, 139-142. [PubMed: 9928824]

Kobierski LA, Wong AE, Srivastava S, Borsook D and Hyman SE (1999) Cyclic AMP-dependent activation of the proenkephalin gene requires phosphorylation of CREB at serine-133 and a Srcrelated kinase. J. Neurochem 73, 129-138. [PubMed: 10386963] 
Koenig E (1961) Mode of regeneration of acetylcholinesterase in cholinergic neurons following irreversible inactivation. J. Neurochem 8, 169-188. [PubMed: 14457701]

Koenig E (1967a) Synthetic mechanisms in the axon. III: stimulation of acetylcholinesterase synthesis by actinomycin-D in the hypoglossal nerve. J. Neurochem 14, 429-435. [PubMed: 6022902]

Koenig E (1967b) Synthetic mechanisms in the axon. IV. In vitro incorporation of [3H]precursors into axonal protein and RNA. J. Neurochem 14, 437-446. [PubMed: 5336968]

Koenig E and Adams P (1982) Local protein synthesizing activity in axonal fields regenerating in vitro. J. Neurochem 39, 386-400. [PubMed: 7086424]

Kohler M, Burnashev N, Sakmann B and Seeburg PH (1993) Determinants of $\mathrm{Ca}^{2+}$ permeability in both TM1 and TM2 of high affinity kainate receptor channels: diversity by RNA editing. Neuron 10, 491-500. [PubMed: 7681676]

Koliou X, Fedonidis C, Kalpachidou T and Mangoura D (2016) Nuclear import mechanism of neurofibromin for localization on the spindle and function in chromosome congression. $\mathrm{J}$. Neurochem 136, 78-91. [PubMed: 26490262]

Kopp E and Ghosh S (1994) Inhibition of NF-kB by sodium salicylate and aspirin. Science 265, 956959. [PubMed: 8052854]

Koriyama Y, Sugitani K, Ogai K and Kato S (2014) Heat shock protein 70 induction by valproic acid delays photoreceptor cell death by N-methyl-N-nitrosourea in mice. J. Neurochem 130, 707-719. [PubMed: 24773621]

Kouzarides T (2007) Chromatin modifications and their function. Cell 128, 693-705. [PubMed: 17320507]

Kozuka C, Yabiku K, Sunagawa S et al. (2012) Brown rice and its component, gamma-oryzanol, attenuate the preference for high-fat diet by decreasing hypothalamic endoplasmic reticulum stress in mice. Diabetes 61, 3084-3093. [PubMed: 22826028]

Kremerskothen J, Kindler S, Finger I, Veltel S and Barnekow A (2006) Postsynaptic recruitment of Dendrin depends on both dendritic mRNA transport and synaptic anchoring. J. Neurochem. 96, 1659-1666. [PubMed: 16464232]

Kristensson K, Olsson Y and Sjostrand J (1971) Axonal uptake and retrograde transport of exogenous proteins in the hypoglossal nerve. Brain Res 32, 399-406. [PubMed: 4109164]

Krohn K, Rozovsky I, Wals P, Teter B, Anderson CP and Finch CE (1999) Glial fibrillary acidic protein transcription responses to transforming growth factor-beta1 and interleukin-1beta are mediated by a nuclear factor-1-like site in the near-upstream promoter. J. Neurochem 72, 13531361. [PubMed: 10098836]

Kruman II and Fowler AK (2014) Impaired one carbon metabolism and DNA methylation in alcohol toxicity. J. Neurochem 129, 770-780. [PubMed: 24521073]

Kubota K, Niinuma Y, Kaneko M, Okuma Y, Sugai M, Omura T, Uesugi M, Uehara T, Hosoi T and Nomura Y (2006) Suppressive effects of 4-phenylbutyrate on the aggregation of Pael receptors and endoplasmic reticulum stress. J. Neurochem 97, 1259-1268. [PubMed: 16539653]

Kumar R, Azam S, Sullivan JM et al. (2001) Brain ischemia and reperfusion activates the eukaryotic initiation factor 2alpha kinase, PERK. J. Neurochem 77, 1418-1421. [PubMed: 11389192]

Laflamme N and Rivest S (1999) Effects of systemic immunogenic insults and circulating proinflammatory cytokines on the transcription of the inhibitory factor kappaB alpha within specific cellular populations of the rat brain. J. Neurochem 73, 309-321. [PubMed: 10386984]

Lakso M, Sauer B, Mosinger B, Jr, Lee EJ, Manning RW, Yu SH, Mulder KL and Westphal H (1992) Targeted oncogene activation by site-specific recombination in transgenic mice. Proc. Natl Acad. Sci. USA 89, 6232-6236. [PubMed: 1631115]

Lambert JC, Ibrahim-Verbaas CA, Harold D et al. (2013) Metaanalysis of 74,046 individuals identifies 11 new susceptibility loci for Alzheimer's disease. Nat. Genet 45, 1452-1458. [PubMed: 24162737]

Lambolez B, Audinat E, Bochet P, Crepel F and Rossier J (1992) AMPA receptor subunits expressed by single Purkinje cells. Neuron 9, 247-258. [PubMed: 1323310]

Landoure G, Sullivan JM, Johnson JO et al. (2012) Exome sequencing identifies a novel TRPV4 mutation in a CMT2C family. Neurology 79, 192-194. [PubMed: 22675077] 
Laorden ML, Nunez C, Almela P and Milanes MV (2002) Morphine withdrawal-induced c-fos expression in the hypothalamic paraventricular nucleus is dependent on the activation of catecholaminergic neurones. J. Neurochem 83, 132-140. [PubMed: 12358736]

Lapham LW (1968) Tetraploid DNA content of Purkinje neurons of human cerebellar cortex. Science 159, 310-312. [PubMed: 5634498]

Lark C (1968) Studies on the in vivo methylation of DNA in Escherichia coli 15T. J. Mol. Biol 31, 389-399. [PubMed: 4866331]

Larson EB, Akkentli F, Edwards S, Graham DL, Simmons DL, Alibhai IN, Nestler EJ and Self DW (2010) Striatal regulation of DeltaFosB, FosB, and cFos during cocaine self-administration and withdrawal. J. Neurochem 115, 112-122. [PubMed: 20633205]

Lee RC, Feinbaum RL and Ambros V (1993) The $C$. elegans heterochronic gene lin-4 encodes small RNAs with antisense complementarity to lin-14. Cell 75, 843-854. [PubMed: 8252621]

Leinfelder W, Zehelein E, Mandrand-Berthelot MA and Bock A (1988) Gene for a novel tRNA species that accepts L-serine and cotranslationally inserts selenocysteine. Nature 331, 723-725. [PubMed: 2963963]

Leypoldt F, Lewerenz J and Methner A (2001) Identification of genes up-regulated by retinoic-acidinduced differentiation of the human neuronal precursor cell line NTERA-2 cl.D1. J. Neurochem 76, 806-814. [PubMed: 11158252]

Li J, Xu M, Zhou H, Ma J and Potter H (1997) Alzheimer presenilins in the nuclear membrane, interphase kinetochores, and centrosomes suggest a role in chromosome segregation. Cell 90, 917-927. [PubMed: 9298903]

Li LC, Okino ST, Zhao H, Pookot D, Place RF, Urakami S, Enokida H and Dahiya R (2006) Small dsRNAs induce transcriptional activation in human cells. Proc. Natl Acad. Sci. USA 103, 1733717342. [PubMed: 17085592]

Lian H, Shim DJ, Gaddam SS, Rodriguez-Rivera J, Bitner BR, Pautler RG, Robertson CS and Zheng $\mathrm{H}$ (2012) IkappaBalpha deficiency in brain leads to elevated basal neuroinflammation and attenuated response following traumatic brain injury: implications for functional recovery. Mol. Neurodegener 7, 47. [PubMed: 22992283]

Lian H, Yang L, Cole A et al. (2015) NFkappaB-activated astroglial release of complement C3 compromises neuronal morphology and function associated with Alzheimer' s disease. Neuron 85, 101-115. [PubMed: 25533482]

Lima SQ and Miesenbock G (2005) Remote control of behavior through genetically targeted photostimulation of neurons. Cell 121, 141-152. [PubMed: 15820685]

Ling ZD, Chang Q, Lipton JW, Tong CW, Landers TM and Carvey PM (2004) Combined toxicity of prenatal bacterial endotoxin exposure and postnatal 6-hydroxydopamine in the adult rat midbrain. Neuroscience 124, 619-628. [PubMed: 14980732]

Lister R, Mukamel EA, Nery JR et al. (2013) Global epigenomic reconfiguration during mammalian brain development. Science 341, 1237905. [PubMed: 23828890]

Listwak SJ, Rathore P and Herkenham M (2013) Minimal NF-kappaB activity in neurons. Neuroscience 250, 282-299. [PubMed: 23872390]

Liu DX and Greene LA (2001) Neuronal apoptosis at the G1/S cell cycle checkpoint. Cell Tissue Res 305, 217-228. [PubMed: 11545259]

Liu H, Nakagawa T, Kanematsu T, Uchida T and Tsuji S (1999) Isolation of 10 differentially expressed cDNAs in differentiated Neuro2a cells induced through controlled expression of the GD3 synthase gene. J. Neurochem 72, 1781-1790. [PubMed: 10217254]

Liu L, Li Y, Van Eldik LJ, Griffin WS and Barger SW (2005) S100B-induced microglial and neuronal IL-1 expression is mediated by cell type-specific transcription factors. J. Neurochem 92, 546553. [PubMed: 15659225]

Liu Y, Kagechika H, Ishikawa J, Hirano H, Matsukuma S, Tanaka K and Nakamura S (2008) Effects of retinoic acids on the dendritic morphology of cultured hippocampal neurons. J. Neurochem 106, 1104-1116. [PubMed: 18466335]

Liu G, Jiang Y, Wang P, Feng R, Jiang N, Chen X, Song H and Chen Z (2012a) Cell adhesion molecules contribute to Alzheimer' s disease: multiple pathway analyses of two genome-wide association studies. J. Neurochem 120, 190-198. [PubMed: 22017384] 
Liu XA, Song J, Jiang Q, Wang Q, Tian Q and Wang JZ (2012b) Expression of the hyperphosphorylated tau attenuates ER stress-induced apoptosis with upregulation of unfolded protein response. Apoptosis 17, 1039-1049. [PubMed: 22802092]

Livet J, Weissman TA, Kang H, Draft RW, Lu J, Bennis RA, Sanes JR and Lichtman JW (2007) Transgenic strategies for combinatorial expression of fluorescent proteins in the nervous system. Nature 450, 56-62. [PubMed: 17972876]

Llorente IL, Burgin TC, Perez-Rodriguez D, Martinez-Villayandre B, Perez-Garcia CC and FernandezLopez A (2013) Unfolded protein response to global ischemia following $48 \mathrm{~h}$ of reperfusion in the rat brain: the effect of age and meloxicam. J. Neurochem 127, 701-710. [PubMed: 23763503]

Loewy AD, Bridgman PC and Mettenleiter TC (1991) beta-Galactosidase expressing recombinant pseudorabies virus for light and electron microscopic study of transneuronally labeled CNS neurons. Brain Res 555, 346-352. [PubMed: 1657302]

Loke SY, Tanaka K and Ong WY (2013) Comprehensive gene expression analyses of the rat prefrontal cortex after oxysterol treatment. J. Neurochem 124, 770-781. [PubMed: 23294445]

Long M, Weir D and Scott J (1989) Source of methyl groups in brain and nerve tissue in the rat. J. Neurochem 52, 377-380. [PubMed: 2911022]

Lopez-Sanchez N and Frade JM (2013) Genetic evidence for p75NTR-dependent tetraploidy in cortical projection neurons from adult mice. J. Neurosci 33, 7488-7500. [PubMed: 23616554]

Luis-Delgado OE, Barrot M, Rodeau JL, Ulery PG, Freund-Mercier MJ and Lasbennes F (2006) The transcription factor DeltaFosB is recruited by inflammatory pain. J. Neurochem 98, 1423-1431. [PubMed: 16787404]

Ma X, Reynolds SL, Baker BJ, Li X, Benveniste EN and Qin H (2010) IL-17 enhancement of the IL-6 signaling cascade in astrocytes. J. Immunol 184, 4898-4906. [PubMed: 20351184]

Machado-Filho JA, Correia AO, Montenegro AB, Nobre ME, Cerqueira GS, Neves KR, NaffahMazzacoratti Mda G, Cavalheiro EA, de Castro Brito GA and de Barros Viana GS (2014) Caffeine neuroprotective effects on 6-OHDA-lesioned rats are mediated by several factors, including pro-inflammatory cytokines and histone deacetylase inhibitions. Behav. Brain Res 264 116-125. [PubMed: 24525422]

MacNicol AM, Wilczynska A and MacNicol MC (2008) Function and regulation of the mammalian Musashi mRNA translational regulator. Biochem. Soc. Trans 36, 528-530. [PubMed: 18481998]

Madrigal JL, Moro MA, Lizasoain I, Lorenzo P, Castrillo A, Bosca L and Leza JC (2001) Inducible nitric oxide synthase expression in brain cortex after acute restraint stress is regulated by nuclear factor kappaB-mediated mechanisms. J. Neurochem 76, 532-538. [PubMed: 11208916]

Manfredi Romanini MG, Fraschini A and Bernocchi G (1973) DNA content and nuclear area in the neurons of the cerebral ganglion in Helix pomatia. Ann. Histochim 18, 49-58. [PubMed: 4758819]

Mao X, Moerman AM and Barger SW (2002) Neuronal kB-binding factors consist of Sp1-related proteins: functional implications for autoregulation of NR1 expression. J. Biol. Chem 277, 44911-44919. [PubMed: 12244044]

Mao XR, Moerman-Herzog AM, Chen Y and Barger SW (2009) Unique aspects of transcriptional regulation in neurons-nuances in NFkappaB and Sp1-related factors. J. Neuroinflammation 6, 16. [PubMed: 19450264]

Mao X, Phanavanh B, Hamdan H, Moerman-Herzog A and Barger SW (2016) NFkappaB-inducing kinase inhibits NFkappaB activity specifically in neurons of the CNS. J. Neurochem 137, 154163. [PubMed: 26778773]

Mares V, Lodin Z and Sacha J (1973) A cytochemical and autoradiographic study of nuclear DNA in mouse Purkinje cells. Brain Res 53, 273-289. [PubMed: 4735887]

Marin MP, Tomas M, Esteban-Pretel G, Megias L, Lopez-Iglesias C, Egea G and Renau-Piqueras J (2008) Chronic ethanol exposure induces alterations in the nucleocytoplasmic transport in growing astrocytes. J. Neurochem 106, 1914-1928. [PubMed: 18547370]

Martin CL, Kirkpatrick BE and Ledbetter DH (2015) Copy number variants, aneuploidies, and human disease. Clin Perinatol. 42, 227-242. [PubMed: 26042902] 
Maskos U, Kissa K, St Cloment C and Brulet P (2002) Retrograde trans-synaptic transfer of green fluorescent protein allows the genetic mapping of neuronal circuits in transgenic mice. Proc. Natl Acad. Sci. USA 99, 10120-10125. [PubMed: 12114537]

Masuyama H and Hiramatsu Y (2012) Effects of a high-fat diet exposure in utero on the metabolic syndrome-like phenomenon in mouse offspring through epigenetic changes in adipocytokine gene expression. Endocrinology 153, 2823-2830. [PubMed: 22434078]

Matsuda Y, Nakanishi N, Dickens G and Guroff G (1986) A nerve growth factor-sensitive S6 kinase in cell-free extracts from PC12 cells. J. Neurochem 47, 1728-1734. [PubMed: 3772374]

McCarthy KM, Tank DW and Enquist LW (2009) Pseudorabies virus infection alters neuronal activity and connectivity in vitro. PLoS Pathog 5, e1000640. [PubMed: 19876391]

McConnell MJ, Lindberg MR, Brennand KJ et al. (2013) Mosaic copy number variation in human neurons. Science 342, 632-637. [PubMed: 24179226]

McFarland NR, Lee JS, Hyman BT and McLean PJ (2009) Comparison of transduction efficiency of recombinant AAV serotypes 1, 2, 5, and 8 in the rat nigrostriatal system. J. Neurochem 109, 838845. [PubMed: 19250335]

McGraw CM, Samaco RC and Zoghbi HY (2011) Adult neural function requires MeCP2. Science 333, 186. [PubMed: 21636743]

Mellen M, Ayata P, Dewell S, Kriaucionis S and Heintz N (2012) MeCP2 binds to 5hmC enriched within active genes and accessible chromatin in the nervous system. Cell 151, 1417-1430. [PubMed: 23260135]

Metzger D, Clifford J, Chiba H and Chambon P (1995) Conditional site-specific recombination in mammalian cells using a ligand-dependent chimeric Cre recombinase. Proc. Natl Acad. Sci. USA 92, 6991-6995. [PubMed: 7624356]

Milagre I, Nunes MJ, Castro-Caldas M, Moutinho M, Gama MJ and Rodrigues E (2012) Neuronal differentiation alters the ratio of Sp transcription factors recruited to the CYP46A1 promoter. J. Neurochem 120, 220-229. [PubMed: 22060190]

Miller S, Yasuda M, Coats JK, Jones Y, Martone ME and Mayford M (2002) Disruption of dendritic translation of CaMKIIalpha impairs stabilization of synaptic plasticity and memory consolidation. Neuron 36, 507-519. [PubMed: 12408852]

Miller RS, Diaczok D and Cooke DW (2007) Repression of GLUT4 expression by the endoplasmic reticulum stress response in 3T3-L1 adipocytes. Biochem. Biophys. Res. Commun 362, 188-192. [PubMed: 17698029]

Miquel P (1888) Monographie d'un bacille vivant au-dela de $70^{\circ}$ centigrades. Ann. Micrographie 1, 310.

Miura K and Niikawa N (2005) Do monochorionic dizygotic twins increase after pregnancy by assisted reproductive technology? J. Hum. Genet 50, 1-6. [PubMed: 15599781]

Miyake SI, Wakita H, Bernstock JD, Castri P, Ruetzler C, Miyake J, Lee YJ and Hallenbeck JM (2015) Hypophosphorylation of ribosomal protein S6 is a molecular mechanism underlying ischemic tolerance induced by either hibernation or preconditioning. J. Neurochem 135, 943-957. [PubMed: 26375300]

Montermini L, Kish SJ, Jiralerspong S, Lamarche JB and Pandolfo M (1997) Somatic mosaicism for Friedreich's ataxia GAA triplet repeat expansions in the central nervous system. Neurology 49, 606-610. [PubMed: 9270608]

Montoliu L and Whitelaw CB (2011) Using standard nomenclature to adequately name transgenes, knockout gene alleles and any mutation associated to a genetically modified mouse strain. Transgenic Res 20, 435-440. [PubMed: 20632206]

Moore AN, Waxham MN and Dash PK (1996) Neuronal activity increases the phosphorylation of the transcription factor cAMP response element-binding protein (CREB) in rat hippocampus and cortex. J. Biol. Chem 271, 14214-14220. [PubMed: 8662977]

Morgan JI and Curran T (1988) Calcium as a modulator of the immediate-early gene cascade in neurons. Cell Calcium 9, 303-311. [PubMed: 3147142]

Morgan JI, Cohen DR, Hempstead JL and Curran T (1987) Mapping patterns of c-fos expression in the central nervous system after seizure. Science 237, 192-197. [PubMed: 3037702] 
Morillo SM, Escoll P, de la Hera A and Frade JM (2010) Somatic tetraploidy in specific chick retinal ganglion cells induced by nerve growth factor. Proc. Natl Acad. Sci. USA 107, 109-114. [PubMed: 20018664]

Mosch B, Morawski M, Mittag A, Lenz D, Tarnok A and Arendt T (2007) Aneuploidy and DNA replication in the normal human brain and Alzheimer's disease. J. Neurosci 27, 6859-6867. [PubMed: 17596434]

Mukaida N, Morita M, Ishikawa Y, Rice N, Okamoto S and Kasahara T (1994) Novel mechanism of glucocorticoid-mediated gene repression. Nuclear factor-kB is target for glucocorticoid-mediated interleukin 8 gene repression. J. Biol. Chem 269, 13289-13295. [PubMed: 8175759]

Mullis K, Faloona F, Scharf S, Saiki R, Horn G and Erlich H (1986) Specific enzymatic amplification of DNA in vitro: the polymerase chain reaction. Cold Spring Harb. Symp. Quant. Biol 51(), 263273. [PubMed: 3472723]

Mummaneni P, Yates P, Simpson J, Rose J and Turker MS (1998) The primary function of a redundant Sp1 binding site in the mouse aprt gene promoter is to block epigenetic gene inactivation. Nucleic Acids Res 26, 5163-5169. [PubMed: 9801314]

Murakami M, Ito H, Hagiwara K et al. (2010) ATRA inhibits ceramide kinase transcription in a human neuroblastoma cell line, SH-SY5Y cells: the role of COUP-TFI. J. Neurochem 112, 511-520. [PubMed: 19903244]

Naidoo N, Giang W, Galante RJ and Pack AI (2005) Sleep deprivation induces the unfolded protein response in mouse cerebral cortex. J. Neurochem 92, 1150-1157. [PubMed: 15715665]

Nakagawa T, Zhu H, Morishima N, Li E, Xu J, Yankner BA and Yuan J (2000) Caspase-12 mediates endoplasmic-reticulum-specific apoptosis and cytotoxicity by amyloid-beta. Nature 403, 98-103. [PubMed: 10638761]

Nakai M, Qin ZH, Chen JF, Wang Y and Chase TN (2000) Kainic acid-induced apoptosis in rat striatum is associated with nuclear factor-kappaB activation. J. Neurochem 74, 647-658. [PubMed: 10646516]

Neasta J, Barak S, Hamida SB and Ron D (2014) mTOR complex 1: a key player in neuroadaptations induced by drugs of abuse. J. Neurochem. 130, 172-184. [PubMed: 24666346]

van Neerven S, Regen T, Wolf D, Nemes A, Johann S, Beyer C, Hanisch UK and Mey J (2010) Inflammatory chemokine release of astrocytes in vitro is reduced by all-trans retinoic acid. J. Neurochem 114, 1511-1526. [PubMed: 20557428]

News Staff. (2010) Insights of the decade. Stepping away from the trees for a look at the forest. Introduction. Science 330, 1612-1613. [PubMed: 21163985]

Nicolini A, Ajmone-Cat MA, Bernardo A, Levi G and Minghetti L (2001) Human immunodeficiency virus type-1 Tat protein induces nuclear factor (NF)-kappaB activation and oxidative stress in microglial cultures by independent mechanisms. J. Neurochem 79, 713-716. [PubMed: 11701774]

Nihongaki Y, Kawano F, Nakajima T and Sato M (2015) Photoactivatable CRISPR-Cas9 for optogenetic genome editing. Nat. Biotechnol 33, 755-760. [PubMed: 26076431]

Nijholt DA, van Haastert ES, Rozemuller AJ, Scheper W and Hoozemans JJ (2012) The unfolded protein response is associated with early tau pathology in the hippocampus of tauopathies. J. Pathol 226, 693-702. [PubMed: 22102449]

Nikcevic G, Savic T, Kovacevic-Grujicic N and Stevanovic M (2008) Up-regulation of the SOX3 gene expression by retinoic acid: characterization of the novel promoter-response element and the retinoid receptors involved. J. Neurochem 107, 1206-1215. [PubMed: 18786169]

No D, Yao TP and Evans RM (1996) Ecdysone-inducible gene expression in mammalian cells and transgenic mice. Proc. Natl Acad. Sci. USA 93, 3346-3351. [PubMed: 8622939]

Nunez C, Martin F, Foldes A, Luisa Laorden M, Kovacs KJ and Victoria Milanes M (2010) Induction of FosB/DeltaFosB in the brain stress system-related structures during morphine dependence and withdrawal. J. Neurochem 114, 475-487. [PubMed: 20438612]

Nussbaum AL, Davoli D, Ganem D and Fareed GC (1976) Construction and propagation of a defective simian virus 40 genome bearing an operator from bacteriophage lambda. Proc. Natl Acad. Sci. USA 73, 1068-1072. [PubMed: 177971] 
O'Brien E, Dolinoy DC and Mancuso P (2014) Perinatal bisphenol A exposures increase production of pro-inflammatory mediators in bone marrow-derived mast cells of adult mice. J. Immunotoxicol 11, 205-212. [PubMed: 23914806]

Ohashi S, Kobayashi S, Omori A, Ohara S, Omae A, Muramatsu T, Li Y and Anzai K (2000) The single-stranded DNA-and RNA-binding proteins pur alpha and pur beta link BC1 RNA to microtubules through binding to the dendrite-targeting RNA motifs. J. Neurochem 75, 17811790. [PubMed: 11032866]

Okano H, Aruga J, Nakagawa T, Shiota C and Mikoshiba K (1991) Myelin basic protein gene and the function of antisense RNA in its repression in myelin-deficient mutant mouse. J. Neurochem 56, 560-567. [PubMed: 1703220]

Ono H (2009) The hypothalamus bridges the gap between physiology and biochemistry in high-fat diet-induced hepatic insulin resistance. Cell Cycle 8, 2885-2887. [PubMed: 19738432]

Oo TF, Henchcliffe C, James D and Burke RE (1999) Expression of c-fos, c-jun, and c-jun N-terminal kinase (JNK) in a developmental model of induced apoptotic death in neurons of the substantia nigra. J. Neurochem 72, 557-564. [PubMed: 9930727]

van der Oost J (2013) Molecular biology. New tool for genome surgery. Science 339, 768-770. [PubMed: 23413345]

Pamphlett R, Cheong PL, Trent RJ and Yu B (2013) Can ALS-associated C9orf72 repeat expansions be diagnosed on a blood DNA test alone? PLoS ONE 8, e70007. [PubMed: 23894576]

Paschen W and Frandsen A (2001) Endoplasmic reticulum dysfunction-a common denominator for cell injury in acute and degenerative diseases of the brain? J. Neurochem 79, 719-725. [PubMed: 11723164]

Paschen W, Mengesdorf T, Althausen S and Hotop S (2001) Peroxidative stress selectively downregulates the neuronal stress response activated under conditions of endoplasmic reticulum dysfunction. J. Neurochem 76, 1916-1924. [PubMed: 11259510]

Paschen W, Yatsiv I, Shoham S and Shohami E (2004) Brain trauma induces X-box protein 1 processing indicative of activation of the endoplasmic reticulum unfolded protein response. J. Neurochem 88, 983-992. [PubMed: 14756820]

Passini MA, Bu J, Richards AM et al. (2011) Antisense oligonucleotides delivered to the mouse CNS ameliorate symptoms of severe spinal muscular atrophy. Sci. Transl. Med 3, 72ra18.

Paterniti I, Genovese T, Mazzon E, Crisafulli C, Di Paola R, Galuppo M, Bramanti P and Cuzzocrea S (2010) Liver X receptor agonist treatment regulates inflammatory response after spinal cord trauma. J. Neurochem 112, 611-624. [PubMed: 19891733]

Paz-Filho G, Wong ML and Licinio J (2011) Ten years of leptin replacement therapy. Obes. Rev 12, e315-e323. [PubMed: 21410864]

Peng PL, Zhong X, Tu W, Soundarapandian MM, Molner P, Zhu D, Lau L, Liu S, Liu F and Lu Y (2006) ADAR2-dependent RNA editing of AMPA receptor subunit GluR2 determines vulnerability of neurons in forebrain ischemia. Neuron 49, 719-733. [PubMed: 16504947]

Perez M, Santa-Maria I, Gomez de Barreda E et al. (2009) Tau-an inhibitor of deacetylase HDAC6 function. J. Neurochem 109, 1756-1766. [PubMed: 19457097]

Perissi V, Staszewski LM, McInerney EM, Kurokawa R, Krones A, Rose DW, Lambert MH, Milburn MV, Glass CK and Rosenfeld MG (1999) Molecular determinants of nuclear receptorcorepressor interaction. Genes Dev 13, 3198-3208. [PubMed: 10617569]

Perry GW, Krayanek SR and Wilson DL (1983) Protein synthesis and rapid axonal transport during regrowth of dorsal root axons. J. Neurochem 40, 1590-1598. [PubMed: 6189968]

Perry EK, Johnson M, Ekonomou A, Perry RH, Ballard C and Attems J (2012) Neurogenic abnormalities in Alzheimer's disease differ between stages of neurogenesis and are partly related to cholinergic pathology. Neurobiol. Dis 47, 155-162. [PubMed: 22504537]

Petrone AB, Simpkins JW and Barr TL (2014) 17beta-estradiol and inflammation: implications for ischemic stroke. Aging Dis 5, 340-345. [PubMed: 25276492]

Pfaffenbach KT, Gentile CL, Nivala AM, Wang D, Wei Y and Pagliassotti MJ (2010) Linking endoplasmic reticulum stress to cell death in hepatocytes: roles of C/EBP homologous protein and chemical chaperones in palmitate-mediated cell death. Am. J. Physiol. Endocrinol. Metab 298, E1027-E1035. [PubMed: 20159858] 
Piech-Dumas KM, Best JA, Chen Y, Nagamoto-Combs K, Osterhout CA and Tank AW (2001) The cAMP responsive element and CREB partially mediate the response of the tyrosine hydroxylase gene to phorbol ester. J. Neurochem. 76, 1376-1385. [PubMed: 11238722]

Pierson TM, Adams DA, Markello T et al. (2012) Exome sequencing as a diagnostic tool in a case of undiagnosed juvenile-onset GM1-gangliosidosis. Neurology 79, 123-126. [PubMed: 22675082]

Pisanello F, Sileo L, Oldenburg IA, Pisanello M, Martiradonna L, Assad JA, Sabatini BL and De Vittorio M (2014) Multipoint-emitting optical fibers for spatially addressable in vivo optogenetics. Neuron 82, 1245-1254. [PubMed: 24881834]

Piskurek O and Okada N (2007) Poxviruses as possible vectors for horizontal transfer of retroposons from reptiles to mammals. Proc. Natl Acad. Sci. USA 104, 12046-12051. [PubMed: 17623783]

Pokorska A, Vanhoutte P, Arnold FJ, Silvagno F, Hardingham GE and Bading H (2003) Synaptic activity induces signalling to CREB without increasing global levels of cAMP in hippocampal neurons. J. Neurochem 84, 447-452. [PubMed: 12558964]

Potter H (1991) Review and hypothesis: Alzheimer disease and Down syndrome-chromosome 21 nondisjunction may underlie both disorders. Am. J. Hum. Genet 48, 1192-1200. [PubMed: 1827946]

Prior CP, Cantor CR, Johnson EM, Littau VC and Allfrey VG (1983) Reversible changes in nucleosome structure and histone $\mathrm{H} 3$ accessibility in transcriptionally active and inactive states of rDNA chromatin. Cell 34, 1033-1042. [PubMed: 6313204]

Raivich G (2008) c-Jun expression, activation and function in neural cell death, inflammation and repair. J. Neurochem 107, 898-906. [PubMed: 18793328]

Rajesh K, Krishnamoorthy J, Kazimierczak U, Tenkerian C, Papadakis AI, Wang S, Huang S and Koromilas AE (2015) Phosphorylation of the translation initiation factor eIF2alpha at serine 51 determines the cell fate decisions of Akt in response to oxidative stress. Cell Death Dis 6, e1591. [PubMed: 25590801]

Rall GF, Mucke L and Oldstone MB (1995) Consequences of cytotoxic T lymphocyte interaction with major histocompatibility complex class I-expressing neurons in vivo. J. Exp. Med 182, 12011212. [PubMed: 7595191]

Rao A and Steward O (1993) Evaluation of RNAs present in synaptodendrosomes: dendritic, glial, and neuronal cell body contribution. J. Neurochem 61, 835-844. [PubMed: 7689643]

Ray KP, Farrow S, Daly M, Talabot F and Searle N (1997) Induction of the E-selectin promoter by interleukin 1 and tumour necrosis factor alpha, and inhibition by glucocorticoids. Biochem. $\mathrm{J}$ 328, 707-715. [PubMed: 9371735]

Redfern CH, Coward P, Degtyarev MY, Lee EK, Kwa AT, Hennighausen L, Bujard H, Fishman GI and Conklin BR (1999) Conditional expression and signaling of a specifically designed Gi-coupled receptor in transgenic mice. Nat. Biotechnol 17, 165-169. [PubMed: 10052353]

Rehen SK, Yung YC, McCreight MP et al. (2005) Constitutional aneuploidy in the normal human brain. J. Neurosci. 25, 2176-2180. [PubMed: 15745943]

Reik W, Collick A, Norris ML, Barton SC and Surani MA (1987) Genomic imprinting determines methylation of parental alleles in transgenic mice. Nature 328, 248-251. [PubMed: 3600805]

Robert JJ, Geoffroy MC, Finiels F and Mallet J (1997) An adenoviral vector-based system to study neuronal gene expression: analysis of the rat tyrosine hydroxylase promoter in cultured neurons. J. Neurochem 68, 2152-2160. [PubMed: 9109543]

Rogers JT, Leiter LM, McPhee J, Cahill CM, Zhan SS, Potter H and Nilsson LN (1999) Translation of the Alzheimer amyloid precursor protein mRNA is up-regulated by interleukin-1 through $5^{\prime}$ untranslated region sequences. J. Biol. Chem 274, 6421-6431. [PubMed: 10037734]

Ron D and Walter P (2007) Signal integration in the endoplasmic reticulum unfolded protein response. Nat. Rev. Mol. Cell Biol 8, 519-529. [PubMed: 17565364]

Roscic A, Baldo B, Crochemore C, Marcellin D and Paganetti P (2011) Induction of autophagy with catalytic mTOR inhibitors reduces huntingtin aggregates in a neuronal cell model. J. Neurochem 119, 398-407. [PubMed: 21854390]

Rossetto D, Avvakumov N and Cote J (2012) Histone phosphorylation: a chromatin modification involved in diverse nuclear events. Epigenetics 7, 1098-1108. [PubMed: 22948226] 
Ryu H, Smith K, Camelo SI et al. (2005) Sodium phenylbutyrate prolongs survival and regulates expression of anti-apoptotic genes in transgenic amyotrophic lateral sclerosis mice. J. Neurochem 93, 1087-1098. [PubMed: 15934930]

Sagar SM, Sharp FR and Curran T (1988) Expression of c-fos protein in brain: metabolic mapping at the cellular level. Science 240, 1328-1331. [PubMed: 3131879]

Saha RN and Pahan K (2007) Differential regulation of Mn-superoxide dismutase in neurons and astroglia by HIV-1 gp120: implications for HIV-associated dementia. Free Radic. Biol. Med 42, 1866-1878. [PubMed: 17512466]

Saiki RK, Scharf S, Faloona F, Mullis KB, Horn GT, Erlich HA and Arnheim N (1985) Enzymatic amplification of beta-globin genomic sequences and restriction site analysis for diagnosis of sickle cell anemia. Science 230, 1350-1354. [PubMed: 2999980]

Saiki RK, Gelfand DH, Stoffel S, Scharf SJ, Higuchi R, Horn GT, Mullis KB and Erlich HA (1988) Primer-directed enzymatic amplification of DNA with a thermostable DNA polymerase. Science 239, 487-491. [PubMed: 2448875]

Sakakibara S and Okano H (1997) Expression of neural RNA-binding proteins in the postnatal CNS: implications of their roles in neuronal and glial cell development. J. Neurosci. 17, 8300-8312. [PubMed: 9334405]

Saleh A, Schapansky J, Smith DR, Young N, Odero GL, Aulston B, Fernyhough P and Glazner GW (2013) Normalization of NF-kappaB activity in dorsal root ganglia neurons cultured from diabetic rats reverses neuropathy-linked markers of cellular pathology. Exp. Neurol 241, 169178. [PubMed: 23159890]

Santi MR, Vicini S, Eldadah B and Neale JH (1994) Analysis by polymerase chain reaction of alpha 1 and alpha 6 GABAA receptor subunit mRNAs in individual cerebellar neurons after whole-cell recordings. J. Neurochem 63, 2357-2360. [PubMed: 7964758]

Sapienza C, Peterson AC, Rossant J and Balling R (1987) Degree of methylation of transgenes is dependent on gamete of origin. Nature 328, 251-254. [PubMed: 3600806]

Sato-Bigbee C, Pal S and Chu AK (1999) Different neuroligands and signal transduction pathways stimulate CREB phosphorylation at specific developmental stages along oligodendrocyte differentiation. J. Neurochem 72, 139-147. [PubMed: 9886064]

Sauer B and Henderson N (1988) Site-specific DNA recombination in mammalian cells by the Cre recombinase of bacteriophage P1. Proc. Natl Acad. Sci. USA 85, 5166-5170. [PubMed: 2839833]

Scheuren N, Bang H, Munster T, Brune K and Pahl A (1998) Modulation of transcription factor NFkappaB by enantiomers of the nonsteroidal drug ibuprofen. Br. J. Pharmacol 123, 645-652. [PubMed: 9517383]

Schwaninger M, Sallmann S, Petersen N, Schneider A, Prinz S, Libermann TA and Spranger M (1999) Bradykinin induces interleukin- 6 expression in astrocytes through activation of nuclear factorkappaB. J. Neurochem 73, 1461-1466. [PubMed: 10501190]

Shea LD and Houchin TL (2004) Modular design of non-viral vectors with bioactive components. Trends Biotechnol 22, 429-431. [PubMed: 15331218]

Sheng M, Thompson MA and Greenberg ME (1991) CREB: a Ca (2+)-regulated transcription factor phosphorylated by calmodulin-dependent kinases. Science 252, 1427-1430. [PubMed: 1646483]

Shin C, McNamara JO, Morgan JI, Curran T and Cohen DR (1990) Induction of c-fos mRNA expression by afterdischarge in the hippocampus of naive and kindled rats. J. Neurochem 55 , 1050-1055. [PubMed: 2117045]

Shirvan A, Ziv I, Machlin T, Zilkha-Falb R, Melamed E and Barzilai A (1997) Two waves of cyclin B and proliferating cell nuclear antigen expression during dopamine-triggered neuronal apoptosis. J. Neurochem 69, 539-549. [PubMed: 9231711]

Sholler GS, Currier EA, Dutta A, Slavik MA, Illenye SA, Mendonca MC, Dragon J, Roberts SS and Bond JP (2013) PCI-24781 (abexinostat), a novel histone deacetylase inhibitor, induces reactive oxygen species-dependent apoptosis and is synergistic with bortezomib in neuroblastoma. J. Cancer Ther. Res 2, 21. [PubMed: 25520806]

Simi A, Edling Y, Ingelman-Sundberg M and Tindberg N (2005) Activation of c-fos by lipopolysaccharide in glial cells via p38 mitogen-activated protein kinase-dependent activation of 
serum or cyclic AMP/calcium response element. J. Neurochem 92, 915-924. [PubMed: 15686494]

Soler-Lopez M, Zanzoni A, Lluis R, Stelzl U and Aloy P (2011) Interactome mapping suggests new mechanistic details underlying Alzheimer's disease. Genome Res 21, 364-376. [PubMed: 21163940]

Sommer B, Keinanen K, Verdoorn TA, Wisden W, Burnashev N, Herb A, Kohler M, Takagi T, Sakmann B and Seeburg PH (1990) Flip and flop: a cell-specific functional switch in glutamateoperated channels of the CNS. Science 249, 1580-1585. [PubMed: 1699275]

Sommer B, Kohler M, Sprengel R and Seeburg PH (1991) RNA editing in brain controls a determinant of ion flow in glutamategated channels. Cell 67, 11-19. [PubMed: 1717158]

Sonnenberg JL, Rauscher FJ, 3rd, Morgan JI and Curran T (1989) Regulation of proenkephalin by Fos and Jun. Science 246, 1622-1625. [PubMed: 2512642]

de Souza N (2013) RNA-guided gene editing. Nat. Methods 10, 189. [PubMed: 23565557]

Sparta DR, Stamatakis AM, Phillips JL, Hovelso N, van Zessen R and Stuber GD (2012) Construction of implantable optical fibers for long-term optogenetic manipulation of neural circuits. Nat. Protoc 7, 12-23.

Spatara ML and Robinson AS (2010) Transgenic mouse and cell culture models demonstrate a lack of mechanistic connection between endoplasmic reticulum stress and tau dysfunction. J. Neurosci. Res 88, 1951-1961. [PubMed: 20143409]

Spencer SE, Sawyer WB, Wada H, Platt KB and Loewy AD (1990) CNS projections to the pterygopalatine parasympathetic preganglionic neurons in the rat: a retrograde transneuronal viral cell body labeling study. Brain Res 534, 149-169. [PubMed: 1705849]

Srinivasan D, Yen JH, Joseph DJ and Friedman W (2004) Cell type-specific interleukin-1beta signaling in the CNS. J. Neurosci 24, 6482-6488. [PubMed: 15269258]

Stephenson ML and Zamecnik PC (1978) Inhibition of Rous sarcoma viral RNA translation by a specific oligodeoxyribonucleotide. Proc. Natl Acad. Sci. USA 75, 285-288. [PubMed: 75546]

Steward O and Levy WB (1982) Preferential localization of polyribosomes under the base of dendritic spines in granule cells of the dentate gyrus. J. Neurosci 2, 284-291. [PubMed: 7062109]

Sturtevant AH (1923) Inheritance of direction of coiling in Limnaea. Science 58, 269-270. [PubMed: 17837785]

Su Y, Cui L, Piao C, Li B and Zhao LR (2013) The effects of hematopoietic growth factors on neurite outgrowth. PLoS ONE 8, e75562. [PubMed: 24116056]

Suberbielle E, Sanchez PE, Kravitz AV, Wang X, Ho K, Eilertson K, Devidze N, Kreitzer AC and Mucke L (2013) Physiologic brain activity causes DNA double-strand breaks in neurons, with exacerbation by amyloid-beta. Nat. Neurosci 16, 613-621. [PubMed: 23525040]

Sutherland GT, Janitz M and Kril JJ (2011) Understanding the pathogenesis of Alzheimer' s disease: will RNA-Seq realize the promise of transcriptomics? J. Neurochem 116, 937-946. [PubMed: 21175619]

Suuronen T, Huuskonen J, Pihlaja R, Kyrylenko S and Salminen A (2003) Regulation of microglial inflammatory response by histone deacetylase inhibitors. J. Neurochem 87, 407-416. [PubMed: 14511118]

Suuronen T, Nuutinen T, Huuskonen J, Ojala J, Thornell A and Salminen A (2005) Anti-inflammatory effect of selective estrogen receptor modulators (SERMs) in microglial cells. Inflamm. Res 54, 194-203. [PubMed: 15953991]

Suzuki H and Matsuoka M (2012) TDP-43 toxicity is mediated by the unfolded protein responseunrelated induction of C/EBP homologous protein expression. J. Neurosci. Res 90, 641-647. [PubMed: 22057717]

Suzuki Y, Wanaka A, Tohyama M and Takagi T (1995) Identification of differenially expressed mRNAs during neuronal differentiation of P19 embryonal carcinoma cells. Neurosci. Res 23, 6571. [PubMed: 7501302]

Swartz FJ and Bhatnagar KP (1981) Are CNS neurons polyploid? A critical analysis based upon cytophotometric study of the DNA content of cerebellar and olfactory bulbar neurons of the bat. Brain Res 208, 267-281. [PubMed: 7214149] 
Takuma H, Kwak S, Yoshizawa T and Kanazawa I (1999) Reduction of GluR2 RNA editing, a molecular change that increases calcium influx through AMPA receptors, selective in the spinal ventral gray of patients with amyotrophic lateral sclerosis. Ann. Neurol 46, 806-815. [PubMed: 10589532]

Tanaka F, Sobue G, Doyu M, Ito Y, Yamamoto M, Shimada N, Yamamoto K, Riku S, Hshizume Y and Mitsuma T (1996) Differential pattern in tissue-specific somatic mosaicism of expanded CAG trinucleotide repeats in dentatorubral-pallidoluysian atrophy, Machado-Joseph disease, and Xlinked recessive spinal and bulbar muscular atrophy. J. Neurol. Sci 135, 43-50. [PubMed: 8926495]

Taniguchi H (2014) Genetic dissection of GABAergic neural circuits in mouse neocortex. Front. Cell. Neurosci 8, 8. [PubMed: 24478631]

Tardieu M, Zerah M, Husson B et al. (2014) Intracerebral administration of adeno-associated viral vector serotype rh.10 carrying human SGSH and SUMF1 cDNAs in children with mucopolysaccharidosis type IIIA disease: results of a phase I/II trial. Hum. Gene Ther 25, 506516. [PubMed: 24524415]

Telenius H, Kremer B, Goldberg YP et al. (1994) Somatic and gonadal mosaicism of the Huntington disease gene CAG repeat in brain and sperm. Nat. Genet 6, 409-414. [PubMed: 8054984]

Thakor N and Holcik M (2012) IRES-mediated translation of cellular messenger RNA operates in eIF2alpha-independent manner during stress. Nucleic Acids Res 40, 541-552. [PubMed: 21917851]

The Huntington's Disease Collaborative Research Group (1993) A novel gene containing a trinucleotide repeat that is expanded and unstable on Huntington's disease chromosomes. The Huntington' s Disease Collaborative Research Group. Cell 72, 971-983. [PubMed: 8458085]

Thomas J, Schaack S and Pritham EJ (2010) Pervasive horizontal transfer of rolling-circle transposons among animals. Genome Biol. Evol 2, 656-664. [PubMed: 20693155]

Toki H, Namikawa K, Su Q, Kiryu-Seo S, Sato K and Kiyama H (1998) Enhancement of extracellular glutamate scavenge system in injured motoneurons. J. Neurochem 71, 913-919. [PubMed: 9721716]

Topcu M, Akyerli C, Sayi A, Toruner GA, Kocoglu SR, Cimbis M and Ozcelik T (2002) Somatic mosaicism for a MECP2 mutation associated with classic Rett syndrome in a boy. Eur. J. Hum. Genet 10, 77-81. [PubMed: 11896459]

Trojanowski JQ, Gonatas JO and Gonatas NK (1981) Conjugates of horseradish peroxidase (HRP) with cholera toxin and wheat germ agglutinin are superior to free HRP as orthogradely transported markers. Brain Res 223, 381-385. [PubMed: 6169406]

Tsuji S (2013) The neurogenomics view of neurological diseases. JAMA Neurol 70, 689-694. [PubMed: 23571861]

Tsuzuki K, Lambolez B, Rossier J and Ozawa S (2001) Absolute quantification of AMPA receptor subunit mRNAs in single hippocampal neurons. J. Neurochem 77, 1650-1659. [PubMed: 11413248]

Valdmanis PN, Lisowski L and Kay MA (2012) rAAV-mediated tumorigenesis: still unresolved after an AAV assault. Mol. Ther 20, 2014-2017. [PubMed: 23131853]

Van Horn MR, Sild M and Ruthazer ES (2013) D-serine as a gliotransmitter and its roles in brain development and disease. Front. Cell. Neurosci 7, 39. [PubMed: 23630460]

Varley KE, Gertz J, Bowling KM et al. (2013) Dynamic DNA methylation across diverse human cell lines and tissues. Genome Res 23, 555-567. [PubMed: 23325432]

Vass R, Ashbridge E, Geser F et al. (2011) Risk genotypes at TMEM106B are associated with cognitive impairment in amyotrophic lateral sclerosis. Acta Neuropathol 121, 373-380. [PubMed: 21104415]

Venner H and Reinert H (1973) Possible role of methylated DNA bases for the transcription of the genetic information. Z. Allg. Mikrobiol 13, 613-624. [PubMed: 4590302]

Vidali G, Boffa LC, Bradbury EM and Allfrey VG (1978) Butyrate suppression of histone deacetylation leads to accumulation of multiacetylated forms of histones $\mathrm{H} 3$ and $\mathrm{H} 4$ and increased DNase I sensitivity of the associated DNA sequences. Proc. Natl Acad. Sci. USA 75, 2239-2243. [PubMed: 276864] 
Waldrop MM (2012) Computer modelling: brain in a box. Nature 482, 456-458. [PubMed: 22358809]

Walker JR and Sevarino KA (1995) Regulation of cytochrome c oxidase subunit mRNA and enzyme activity in rat brain reward regions during withdrawal from chronic cocaine. J. Neurochem 64, 497-502. [PubMed: 7830041]

Wallen-Mackenzie A, Mata de Urquiza A, Petersson S et al. (2003) Nurr1-RXR heterodimers mediate RXR ligand-induced signaling in neuronal cells. Genes Dev 17, 3036-3047. [PubMed: 14681209]

Walsh AM, Kortschak RD, Gardner MG, Bertozzi T and Adelson DL (2013) Widespread horizontal transfer of retrotransposons. Proc. Natl Acad. Sci. USA 110, 1012-1016. [PubMed: 23277587]

Wang D and Baldwin AS, Jr (1998) Activation of nuclear factor-kappaB-dependent transcription by tumor necrosis factor-alpha is mediated through phosphorylation of RelA/p65 on serine 529. J. Biol. Chem 273, 29411-29416. [PubMed: 9792644]

Wang X, Li W, Williams M, Terada N, Alessi DR and Proud CG (2001) Regulation of elongation factor 2 kinase by p90(RSK1) and p70 S6 kinase. EMBO J 20, 4370-4379. [PubMed: 11500364]

Wang L, Schuster GU, Hultenby K, Zhang Q, Andersson S and Gustafsson JA (2002) Liver X receptors in the central nervous system: from lipid homeostasis to neuronal degeneration. Proc. Natl Acad. Sci. USA 99, 13878-13883. [PubMed: 12368482]

Wang HQ, Imai Y, Inoue H, Kataoka A, Iita S, Nukina N and Takahashi R (2008a) Pael-R transgenic mice crossed with parkin deficient mice displayed progressive and selective catecholaminergic neuronal loss. J. Neurochem 107, 171-185. [PubMed: 18691389]

Wang IF, Wu LS, Chang HY and Shen CK (2008b) TDP-43, the signature protein of FTLD-U, is a neuronal activity-responsive factor. J. Neurochem 105, 797-806. [PubMed: 18088371]

Wang W, Bu B, Xie M, Zhang M, Yu Z and Tao D (2009) Neural cell cycle dysregulation and central nervous system diseases. Prog. Neurobiol 89, 1-17. [PubMed: 19619927]

Weible AP, Schwarcz L, Wickersham IR, Deblander L, Wu H, Callaway EM, Seung HS and Kentros CG (2010) Transgenic targeting of recombinant rabies virus reveals monosynaptic connectivity of specific neurons. J. Neurosci 30, 16509-16513. [PubMed: 21147990]

Westra JW, Barral S and Chun J (2009) A reevaluation of tetraploidy in the Alzheimer's disease brain. Neurodegener. Dis 6, 221-229. [PubMed: 19738367]

Wickersham IR, Lyon DC, Barnard RJ, Mori T, Finke S, Conzelmann KK, Young JA and Callaway EM (2007) Monosynaptic restriction of transsynaptic tracing from single, genetically targeted neurons. Neuron 53, 639-647. [PubMed: 17329205]

Wightman B, Ha I and Ruvkun G (1993) Posttranscriptional regulation of the heterochronic gene lin-14 by lin- 4 mediates temporal pattern formation in $C$. elegans. Cell 75, 855-862. [PubMed: 8252622]

Williams CA, Wallace MR, Drury KC et al. (2004) Blood lymphocyte chimerism associated with IVF and monochorionic dizygous twinning: case report. Hum. Reprod 19, 2816-2821. [PubMed: 15375077]

Wolff GL, Kodell RL, Moore SR and Cooney CA (1998) Maternal epigenetics and methyl supplements affect agouti gene expression in Avy/a mice. FASEB J 12, 949-957. [PubMed: 9707167]

Worgall S, Sondhi D, Hackett NR et al. (2008) Treatment of late infantile neuronal ceroid lipofuscinosis by CNS administration of a serotype 2 adeno-associated virus expressing CLN2 cDNA. Hum. Gene Ther 19, 463-474. [PubMed: 18473686]

Wu S-Z and Barger SW (2004) Serine racemase induction by inflammatory stimuli is dependent on AP-1. Ann. N. Y. Acad. Sci 1035, 133-146. [PubMed: 15681805]

Wu BW, Engel EA and Enquist LW (2014) Characterization of a replication-incompetent pseudorabies virus mutant lacking the sole immediate early gene IE180. MBio 5, e01850. [PubMed: 25389174]

Xia T, Cheng Y, Zhang Q, Xiao F, Liu B, Chen S and Guo F (2012) S6K1 in the central nervous system regulates energy expenditure via MC4R/CRH pathways in response to deprivation of an essential amino acid. Diabetes 61, 2461-2471. [PubMed: 22787141] 
Xie W, Barr CL, Kim A, Yue F, Lee AY, Eubanks J, Dempster EL and Ren B (2012) Base-resolution analyses of sequence and parent-of-origin dependent DNA methylation in the mouse genome. Cell 148, 816-831. [PubMed: 22341451]

Xie R, Wang P, Ji X and Zhao H (2013) Ischemic post-conditioning facilitates brain recovery after stroke by promoting Akt/mTOR activity in nude rats. J. Neurochem 127, 723-732. [PubMed: 23777415]

Xu J, Barger SW and Drew PD (2008) The PPAR-gamma agonist 15-deoxy-delta-prostaglandin J(2) attenuates microglial production of IL-12 family cytokines: potential relevance to Alzheimer's disease. PPAR Res 2008, 349185. [PubMed: 18615183]

Yagita Y, Kitagawa K, Taguchi A, Ohtsuki T, Kuwabara K, Mabuchi T, Matsumoto M, Yanagihara T and Hori M (1999) Molecular cloning of a novel member of the HSP110 family of genes, ischemia-responsive protein $94 \mathrm{kDa}$ (irp94), expressed in rat brain after transient forebrain ischemia. J. Neurochem 72, 1544-1551. [PubMed: 10098860]

Yamashita T, Yamauchi A, Miyai A, Taniguchi M, Yoshimine T and Tohyama M (1999) Differential regulation of adenine nucleotide translocators by hypertonicity in the brain. J. Neurochem 72, 1259-1265. [PubMed: 10037499]

Yang Y, Geldmacher DS and Herrup K (2001) DNA replication precedes neuronal cell death in Alzheimer's disease. J. Neurosci 21, 2661-2668. [PubMed: 11306619]

Yang Y, Qin X, Liu S, Li J, Zhu X, Gao T and Wang X (2011) Peroxisome proliferator-activated receptor gamma is inhibited by histone deacetylase 4 in cortical neurons under oxidative stress. J. Neurochem 118, 429-439. [PubMed: 21605119]

Yellajoshyula D, Patterson ES, Elitt MS and Kroll KL (2011) Geminin promotes neural fate acquisition of embryonic stem cells by maintaining chromatin in an accessible and hyperacetylated state. Proc. Natl Acad. Sci. USA 108, 3294-3299. [PubMed: 21300881]

Yoshida K, Imaki J, Matsuda H and Hagiwara M (1995) Light-induced CREB phosphorylation and gene expression in rat retinal cells. J. Neurochem 65, 1499-1504. [PubMed: 7561843]

Yoshihara T, Ishigaki S, Yamamoto M, Liang Y, Niwa J, Takeuchi H, Doyu M and Sobue G (2002) Differential expression of inflammation-and apoptosis-related genes in spinal cords of a mutant SOD1 transgenic mouse model of familial amyotrophic lateral sclerosis. J. Neurochem 80 , 158167. [PubMed: 11796754]

Yoshioka A, Hardy M, Younkin DP, Grinspan JB, Stern JL and Pleasure D (1995) Alpha-amino-3hydroxy-5-methyl-4-isoxazolepropionate (AMPA) receptors mediate excitotoxicity in the oligodendroglial lineage. J. Neurochem 64, 2442-2448. [PubMed: 7539052]

You JS, Kelly TK, De Carvalho DD, Taberlay PC, Liang G and Jones PA (2011) OCT4 establishes and maintains nucleosome-depleted regions that provide additional layers of epigenetic regulation of its target genes. Proc. Natl Acad. Sci. USA 108, 14497-14502. [PubMed: 21844352]

Zagrodnick J and Kaufner HK (1990) Ambulatory thromboembolism prevention in traumatology using self-injection of heparin. Unfallchirurg 93, 331-333. [PubMed: 2116667]

Zamecnik PC and Stephenson ML (1978) Inhibition of Rous sarcoma virus replication and cell transformation by a specific oligodeoxynucleotide. Proc. Natl Acad. Sci. USA 75, 280-284. [PubMed: 75545]

Zamore PD, Tuschl T, Sharp PA and Bartel DP (2000) RNAi: double-stranded RNA directs the ATPdependent cleavage of mRNA at 21 to 23 nucleotide intervals. Cell 101, 25-33. [PubMed: 10778853]

Zhang P, Abdelmohsen K, Liu Y et al. (2015) Novel RNA- and FMRP-binding protein TRF2-S regulates axonal mRNA transport and presynaptic plasticity. Nat. Commun 6, 8888. [PubMed: 26586091]

Zheng B, Sage M, Sheppeard EA, Jurecic V and Bradley A (2000) Engineering mouse chromosomes with Cre-loxP: range, efficiency, and somatic applications. Mol. Cell. Biol 20, 648-655. [PubMed: 10611243] 


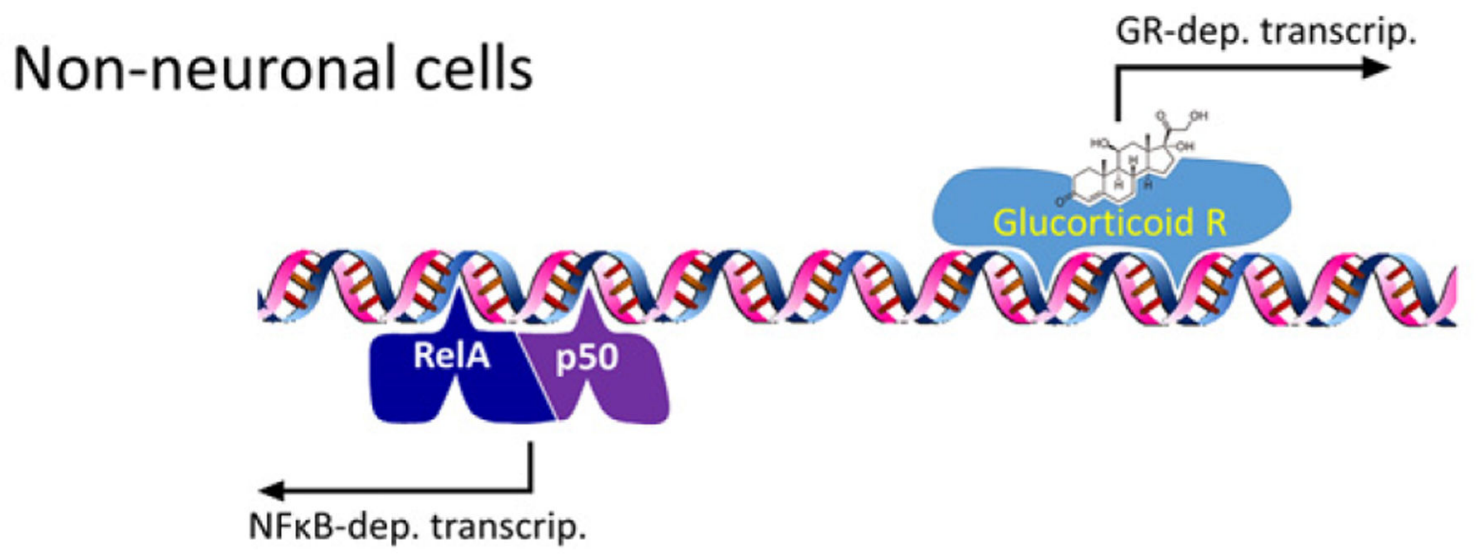

Neurons

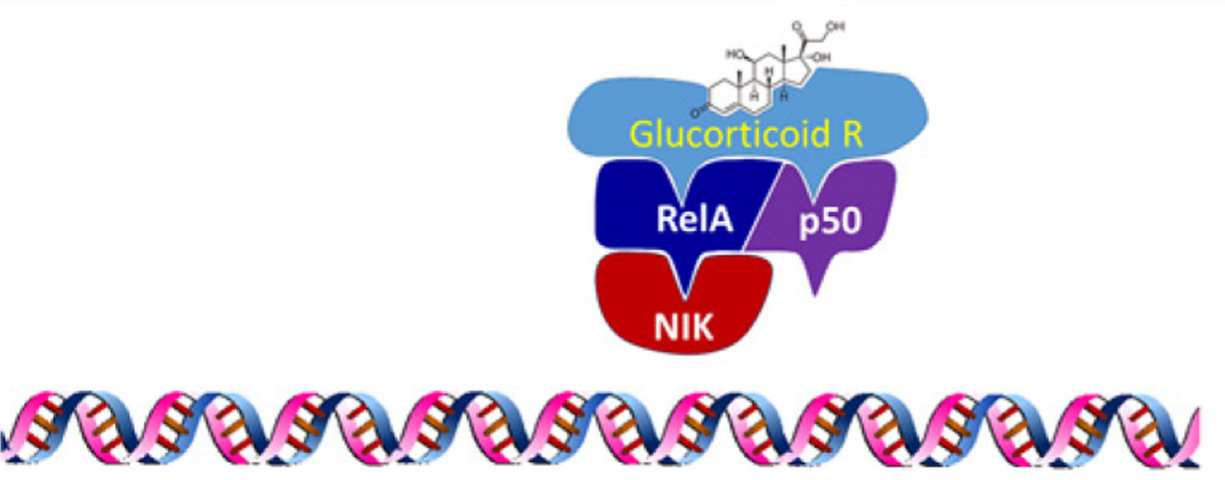

Fig. 1.

Hypothetical alternative actions of NFkB in neuronal nuclei. Though DNA binding by $\mathrm{NFKB}$ is scant in mature CNS neurons, it has been documented to undergo nuclear translocation in these cells, and its expression can have biological effects therein. The hypothesis is depicted that activation of the NFKB pathway in neurons may result in proteinprotein interactions in the nucleus of neurons that could indirectly affect gene expression via an influence on other transcription factors such as the glucocorticoid receptors. NFkBinducing kinase was recently found to participate in the inhibition of $\mathrm{NFKB}$ in neurons. 


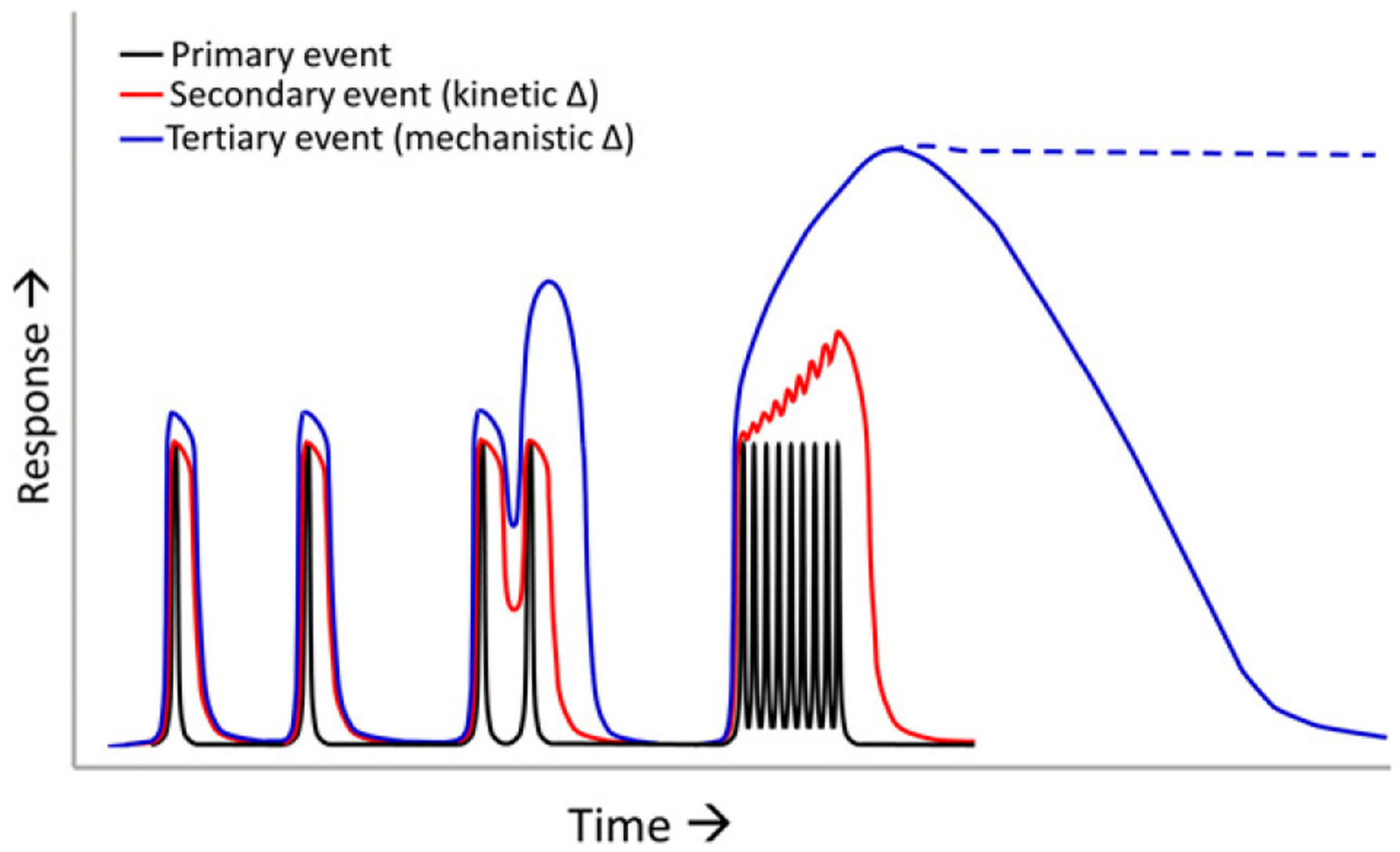

Fig. 2.

Integration of effects by progressive signal transduction. Most neuroscientists are accustomed to interpreting electrophysiological events (e.g. depolarization spikes) that summate in an additive fashion. This type of integration is often manifest in a chain of events for which the secondary response simply has longer decay kinetics, such that a subsequent primary event can arrive before the secondary event has time to dissipate. For instance, opening of a ligand-gated sodium channel can evoke conductance as a primary event; the resulting depolarization can open a calcium channel as a secondary event, which may exhibit a difference in kinetics, e.g. have a longer mean open time. Tertiary signaling events may differ not only in kinetics but also in mechanism, perhaps catalytically extrapolating the effect size; e.g. activation of a calcium-calmodulin kinase. In this way, a quantitative difference becomes a qualitative one. Similar to these ionic integrations, gene regulation events can act as molecular switches that convert a quantitative change, e.g. repeatedly reaching the activity threshold to activate $\mathrm{CREB}$, to a qualitative one, e.g. a level of CREB-dependent transcription that changes histone acetylation. These can even become semipermanent changes (dashed line), e.g. gene activity levels that change DNA methylation patterns via 'molecular momentum' (below). 


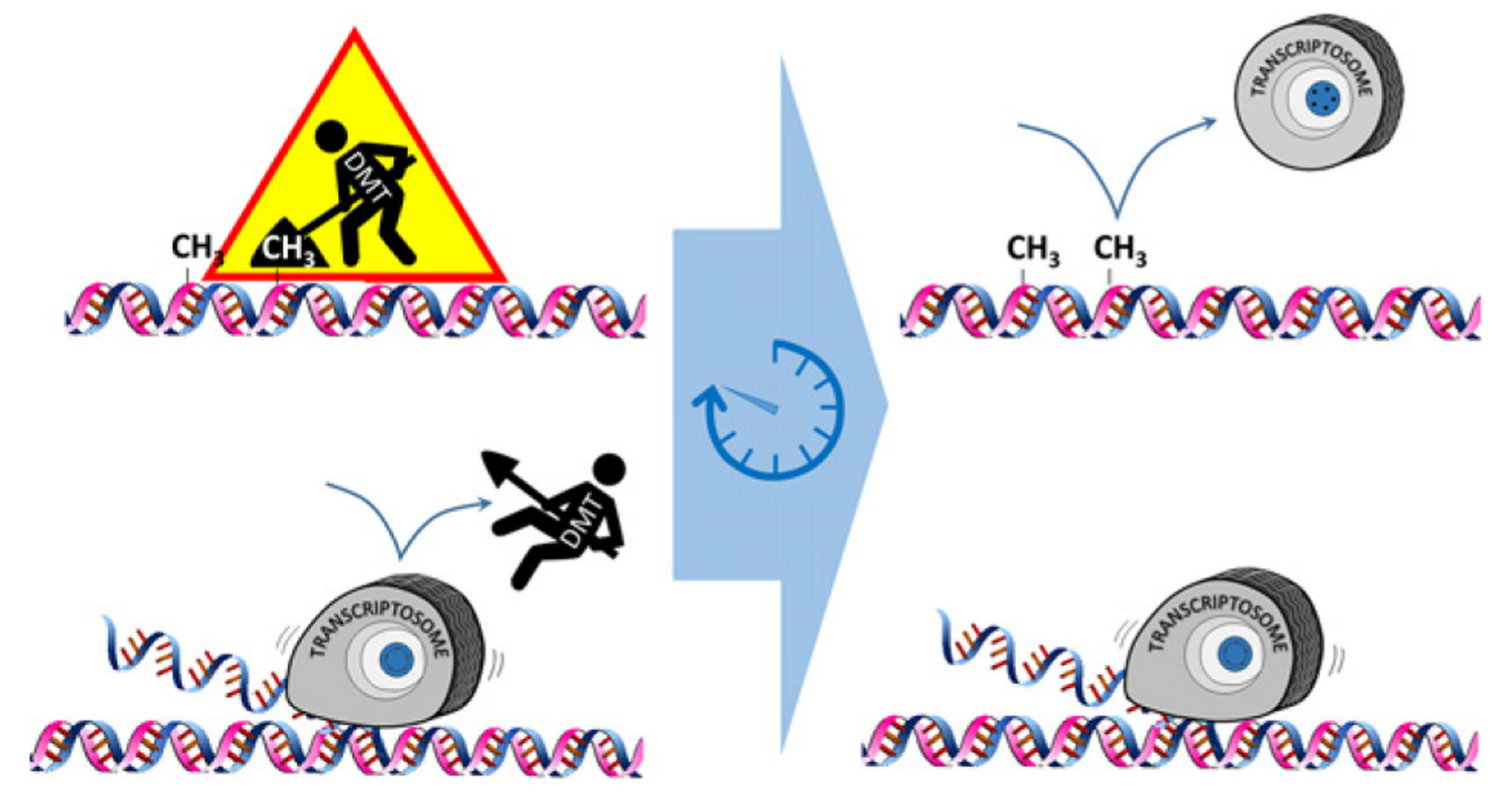

Fig. 3.

Molecular momentum. The rich get richer, and active genes tend to stay active. Perhaps, by a process as simple as steric interference by RNA polymerase and its accompanying proteins, the transcriptional process appears to inhibit DNA methyltransferases (DMT) from modifying an active gene. If this persists over the passage of time, particularly through a developmental stage that is especially plastic, the gene may remain hypomethylated into adulthood, thus adapting the individual to express higher levels of the gene. Similar events may impact other epigenetic processes, such as histone modification. The consequences may be adaptive, e.g. elevating appetite for a scarce nutrient, or maladaptive, e.g. sensitizing the inflammatory genes to aberrant activation. 


\section{Critical cells}

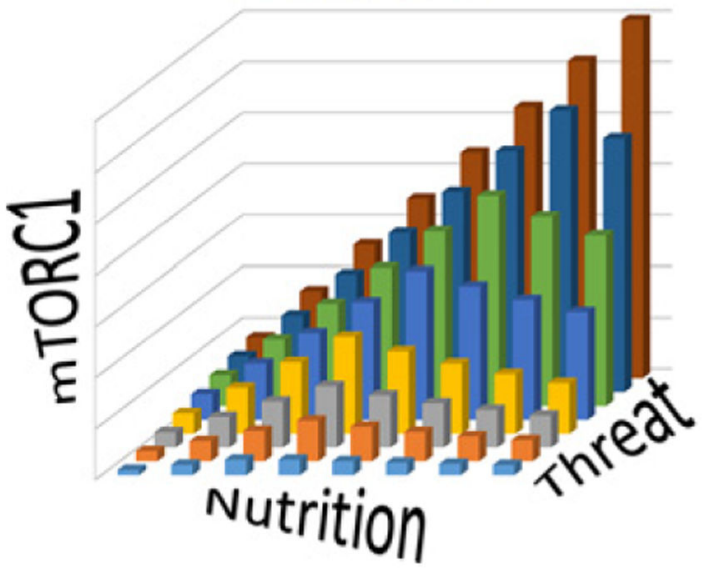

Expendable cells

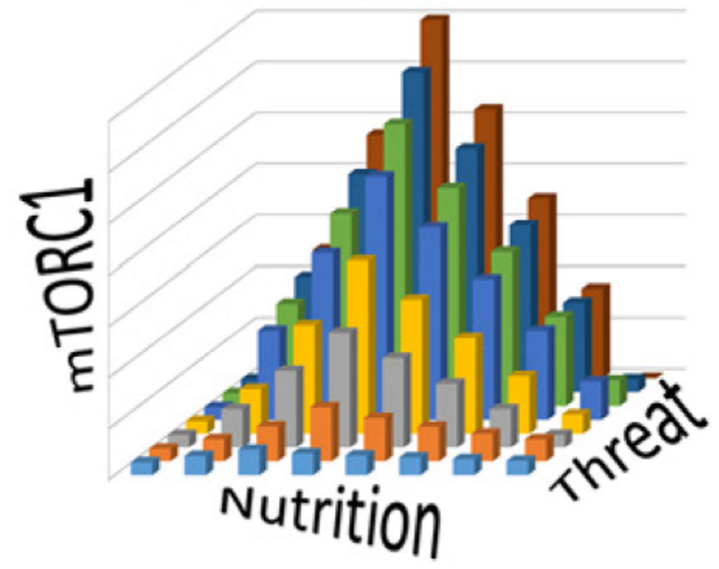

Fig. 4.

Theoretical consequences of mTORC1 activation for various cell types. On the front, (x)axis is the availability of food, increasing left to right. On the receding (y)-axis is the challenge or threat to survival an individual cell may face, increasing front to back. On the elevation, (z)-axis is the optimal activity of mTORC1. Critical cells may be essential neurons in a simple invertebrate or, in the extreme, the entire individual in the case of a unicellular species; expendable cells are those that may be sacrificed because of a high natural renewal rate, for instance. Benefits to life span are generally seen after inhibition of mTORC1 (e.g. with rapamycin) in many species, including yeast. But, this may be limited to circumstances with little stress; life span may benefit from neuroprotection, for instance, that results from elevated protein synthesis and other consequences of mTORC1 activity in stressful situations. This is difficult to engage when nutrition is limited. Perhaps, more to the point, excessive food can lead to shortening of life span -as well as detrimental effects along the way - unless mTORC1 is inhibited. It is possible that benefits to the intact organism may arise from inhibition of mTORC1 in less critical cells, even when these expendable cells are challenged with stressors. 


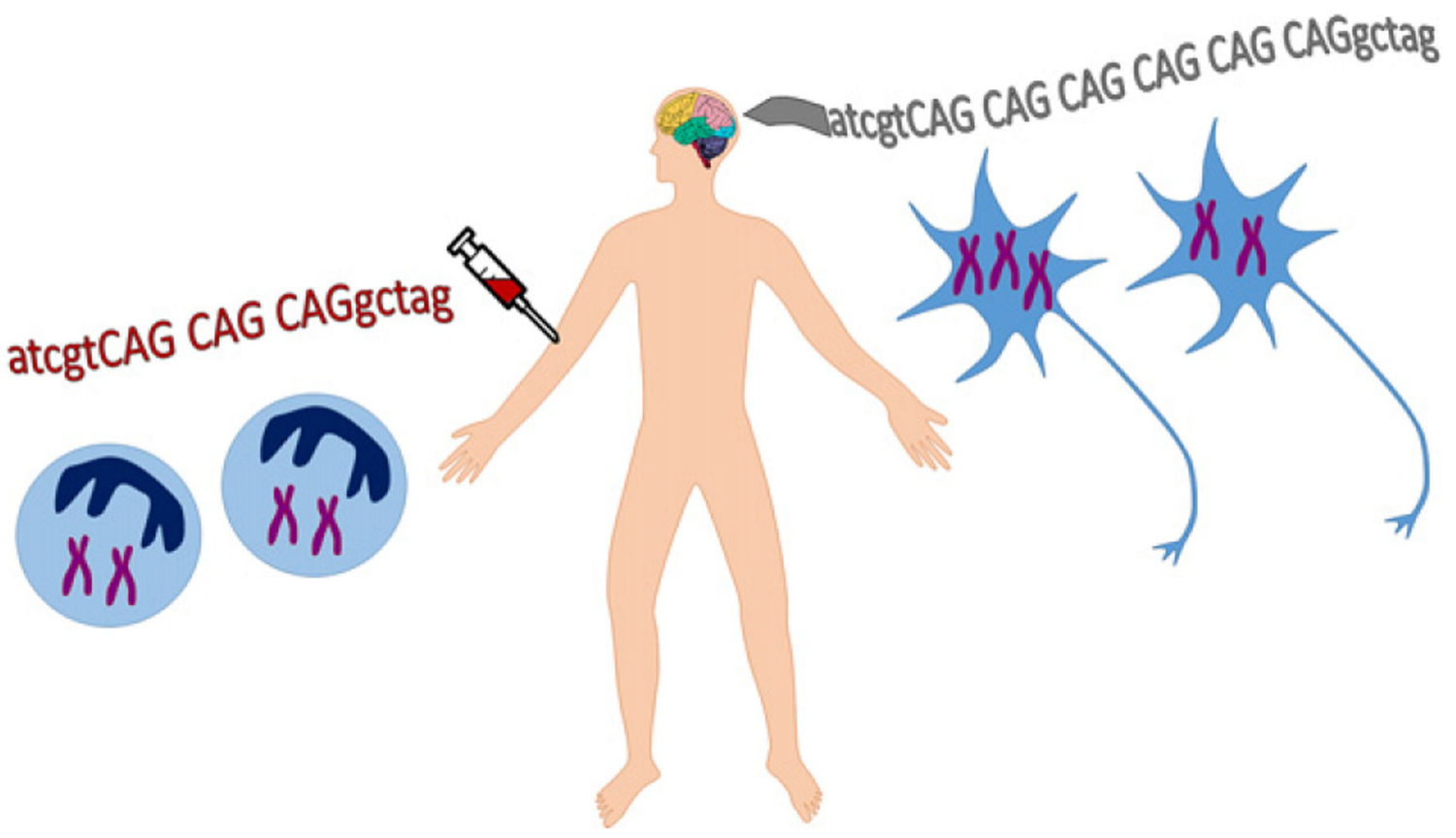

Fig. 5.

Somatic mosaicism and peripheral-central variations. Genetic variation appears to be particularly abundant in the CNS. Copy number variants, extension of tri-or hexanucleotide repeats, and aneuploidy of entire chromosomes that are limited to this compartment may cause disease or less consequential effects in the nervous system while remaining cryptic to DNA sequence analyses that are performed on blood or other peripheral tissue specimens. 


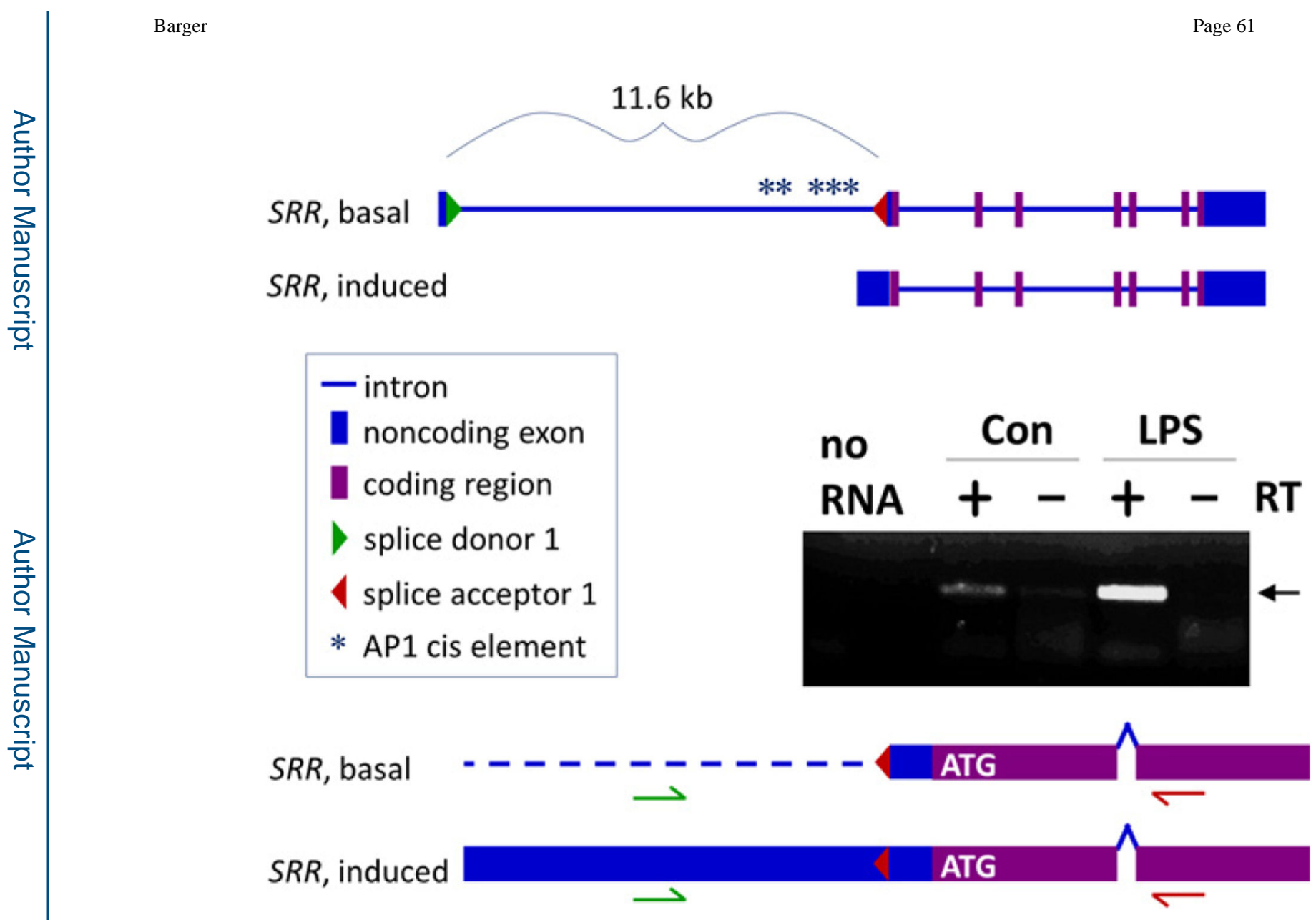

Fig. 6.

PCR demonstrates alternative transcription of the serine racemase gene. Organization of the human serine racemase ( $S R R)$ gene is shown; the canonical transcript produced basally, with the full-length Intron 1 is at top. LPS was previously found to induce expression in microglia via a cluster of AP-1 transcription factor binding sites found just $5^{\prime}$ to the translational start site, and an alternative transcript was postulated to result from a nearby alternative transcriptional start site. The potential mRNA species are diagrammed at the bottom, with the dashed region representing the canonical Intron 1 and the coding region in purple. RTPCR reactions were run with an upstream primer (green) that should be omitted from the mature mRNA by splicing out of Intron 1; this region may be maintained, however, in the alternative transcript because of the removal of the Intron-1 splice donor. The downstream primer (red) was placed in Exon 3 to exclude hnRNA. Microglia treated with LPS were compared to controls, and the RT-PCR results indicate the presence of a product consistent with the alternative transcript, particularly elevated in LPS-treated cells. 